FARLEY ROBERTO RODRIGUES DE CARVALHO FERREIRA

\title{
A INCAPACIDADE TEMPORÁRIA POR DOENÇA NO CONTRATO DE TRABALHO
}

\author{
Dissertação de Mestrado \\ Orientador: Homero Batista Mateus da Silva
}

UNIVERSIDADE DE SÃO PAULO

FACULDADE DE DIREITO

São Paulo

2015 


\section{FARLEY ROBERTO RODRIGUES DE CARVALHO FERREIRA}

\section{A INCAPACIDADE TEMPORÁRIA POR DOENÇA NO CONTRATO DE TRABALHO}

Dissertação apresentada à Banca Examinadora do Programa de Pós-Graduação em Direito, da Faculdade de Direito da Universidade de São Paulo, como exigência parcial para obtenção do título de mestre em Direito, na área de concentração do Direito do Trabalho e Seguridade Social, sob a orientação do Professor Homero Batista Mateus da Silva.

\section{UNIVERSIDADE DE SÃO PAULO \\ FACULDADE DE DIREITO \\ São Paulo \\ 2015}


Serviço de Biblioteca e Documentação

Faculdade de Direito da Universidade de São Paulo

Ferreira, Farley Roberto Rodrigues de Carvalho

A incapacidade temporária por doença no contrato de trabalho / Farley Roberto Rodrigues de Carvalho Ferreira ; orientador Homero Batista Mateus da Silva -- São Paulo, 2015.

181

Dissertação (Mestrado - Programa de Pós-Graduação em Direito do Trabalho e Seguridade Social) - Faculdade de Direito, Universidade de São Paulo, 2015.

1. Direito do Trabalho. 2. Licença médica. 3. Suspensão do contrato de trabalho. 4. Efeitos no contrato de trabalho. I. Silva, Homero Batista Mateus da, orient. II. Título. 
Nome: FERREIRA, Farley Roberto Rodrigues de Carvalho

Título: A incapacidade temporária por doença no contrato de trabalho

Aprovado em:

$1+1$

Dissertação apresentada à Banca Examinadora do Programa de Pós-Graduação em Direito, da Faculdade de Direito da Universidade de São Paulo, como exigência parcial para obtenção do título de mestre em Direito, na área de concentração do Direito do Trabalho e Seguridade Social, sob a orientação do Professor Homero Batista Mateus da Silva.

BANCA EXAMINADORA

Professor:

Instituição:

Julgamento:

Assinatura:

Professor:

Instituição:

Julgamento:

Assinatura:

Professor:

Instituição:

Julgamento:

Assinatura: 


\section{AGRADECIMENTOS}

Agradeço ao Professor Homero Batista Mateus da Silva, que não somente me confiou a oportunidade para desenvolver o presente trabalho, como me apoiou em momentos de desesperos para conseguir a sua conclusão, originados por doença em minha família.

Presenciei que, além de magnífico professor, doutrinador e magistrado, é um ser humano iluminado que compreende as dificuldades das pessoas a seu redor.

Minhas reverências ao eterno professor.

Agradeço a todos meus familiares pelo carinho e dedicação que sempre me destinaram, em especial à minha esposa e à minha mãe, na esperança de que não Ihes falte saúde para enfrentar o porvir. Aos meus filhos, pelo incrível sentimento de conviver com a suave molecagem dessas crianças.

Aos amigos a quem compartilho angústias e felicidades.

Por fim, agradeço ao bom Deus que distribui a justiça de maneira ímpar.

Muito obrigado. 


\section{RESUMO}

FERREIRA, Farley Roberto Rodrigues de Carvalho. A incapacidade temporária por doença no contrato de trabalho. 178. Dissertação de Mestrado - Faculdade de Direito, Universidade de São Paulo, 2015.

A ausência de sistematização jurídica no tratamento da incapacidade temporária por doença no contrato de trabalho propicia soluções jurídicas particularizadas, às vezes antagônicas, pelo operador do Direito do Trabalho. O objetivo do presente trabalho, a partir dessas premissas, foi encontrar aspectos comuns para se propor essa sistematização. Iniciou-se com a abordagem histórica da incapacidade laborativa, suas origens, as normas de direito internacional e no ordenamento jurídico brasileiro aplicáveis ao tema. Posteriormente, estudaram-se a definição e a amplitude da incapacidade por doença, bem como sua contextualização no ambiente de trabalho. A partir disso, possibilitou-se a verificação de seu reconhecimento concreto no contrato de trabalho, por meio da aferição de seus elementos caracterizadores. Não se olvidou a abordagem de questões polêmicas como a ordem preferencial de atestados médicos, o prazo para entrega desses documentos ao empregador, o encaminhamento do empregado à previdência social, bem como as situações especiais de empregados que não recebem o auxílio-doença pela previdência social. Por fim, analisaram-se os efeitos da incapacidade no contrato de trabalho, com especial referência à suspensão da obrigação de fazer consistente em prestar serviços pelo empregado em razão de fortuito, que não impede a vigência de todas as demais cláusulas do contrato de trabalho, que somente são afastadas quando inerentes ou relacionadas à efetiva prestação de serviço. Esse entendimento pautou a análise dos institutos trabalhistas, sem prejuízo no apontamento de outros entendimentos majoritários. Substanciou-se o estudo com jurisprudência atualizada e na rara doutrina especializada existente sobre o tema.

Palavras-chave: Direito do Trabalho. Contrato de trabalho. Incapacidade de trabalho por doença. Suspensão do contrato de trabalho. Efeitos. 


\section{RIASSUNTO}

FERREIRA, Farley Roberto Rodrigues de Carvalho. L'inabilità temporanea a causa di malattia nel contratto di lavoro. 178. Dissertação de Mestrado - Faculdade de Direito, Universidade de São Paulo, 2015.

L'assenza di sistematizzazione giuridica nel trattamento di inabilità temporanea a causa di malattia nel contratto di lavoro fornisce soluzioni giuridiche individuali, a volte antagoniste, la legge sul lavoro dell'operatore. Lo scopo di questo studio, da queste premesse, era di trovare punti in comune per proporre tale sistematizzazione. E 'iniziato con l'approccio storico di disabilità di lavoro, le sue origini, le norme del diritto internazionale e il sistema giuridico brasiliano applicabili al soggetto. In seguito, ha studiato la definizione e la misura della disabilità da malattia e il suo contesto nei luoghi di lavoro. Da questo, possibile controllare il suo riconoscimento effettivo nel contratto di lavoro, mediante la misurazione dei suoi elementi caratteristici. NON abbiamo dimenticato l'approccio alle questioni controverse come l'ordine preferito dei certificati medici, il termine per la consegna di questi documenti al datore di lavoro, il rinvio lavoratore alla sicurezza sociale, nonché la particolare situazione dei lavoratori non ha diritto a ricezione delle prestazioni di malattia, di sicurezza sociale. Infine, gli effetti della disabilità nel contratto di lavoro è stato analizzato, con particolare riferimento alla sospensione dell'obbligo di fornire un servizio coerente dal dipendente a seguito di casuale, non esclude la presenza di tutte le altre clausole del contratto di lavoro, che vengono rimossi solo quando inerenti o connessi alla fornitura di servizi efficaci. Questa comprensione ha guidato l'analisi degli istituti di lavoro, fatte salve la nomina di altre intese di maggioranza. Si sostanzia lo studio con la giurisprudenza aggiornato e nella rara letteratura specializzata esistente sul tema.

Parole chiave: Diritto del Lavoro. Contratto di lavoro. Inabilità al lavoro per malattia. Sospensione del contratto di lavoro. Effetti. 


\section{SUMÁRIO}

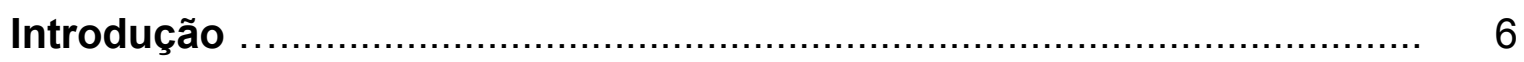

1. Justificativa e importância do tema ....................................................... 6

2. Delimitação do tema ........................................................................... 7

1. A evolução histórica da incapacidade laborativa ............................. 10

1.1. Evolução histórica no âmbito internacional ................................... 10

1.2. Evolução histórica no âmbito nacional .......................................... 17

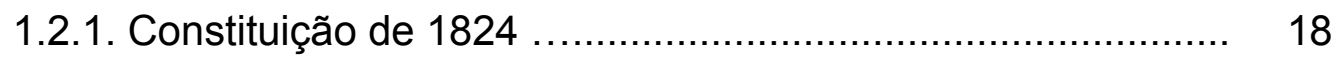

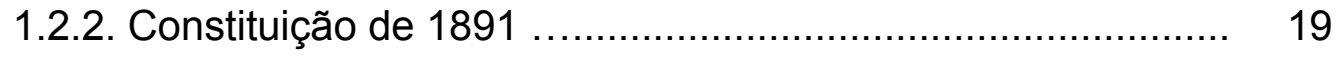

1.2.3. Constituição de 1934 ...................................................... 21

1.2.4. Constituição de 1937 .................................................. 23

1.2.5. Constituição de 1946 ...................................................... 27

1.2.6. Constituição de 1967 e EC no 1 de 1969 ............................ 29

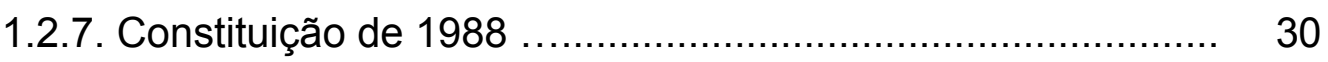

2. A incapacidade laborativa por doença .......................................... 31

2.1. Definição de incapacidade laborativa por doença .......................... 31

2.2. Classificação da incapacidade ................................................. 38

2.2.1. Quanto ao grau .......................................................... 39

2.2.2. Quanto à duração ........................................................ 41

2.2.3. Quanto à profissão ..................................................... 46

3. 0 reconhecimento da incapacidade laborativa ................................ 49

3.1. Caracterização no contrato de trabalho ....................................... 49

3.2. Os primeiros 15 dias (30 dias após a MP 664/2014) ..................... 53

3.2.1. A comprovação da incapacidade laborativa ...................... 54

3.2.2. O prazo para entrega de atestados ou submissão ao

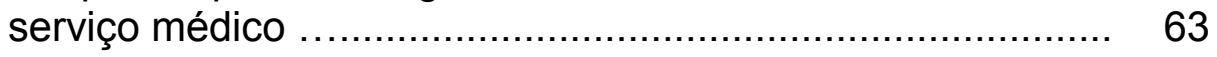

3.2.3. A prorrogação dos afastamentos inferiores a 15 dias (a 30 dias após MP 664/2014) ............................................. 66

3.3. Incapacidade a partir do $16^{\circ}$ dia $\left(31^{\circ}\right.$ dia após a MP 664/2014) ..... 69

3.3.1. A apresentação de requerimento de auxílio-doença pelo empregador

3.4. Situações especiais (empregado em período de carência, 
aposentado e portador de doença anterior à filiação previdenciária) 74

4. Efeitos da incapacidade temporária no contrato de trabalho ............ 77

4.1. Suspensão e interrupção do contrato de trabalho ...................... 77

4.2. A suspensão contratual decorrente da incapacidade laborativa ..... 83

4.2.1. Prescrição ............................................................. 85

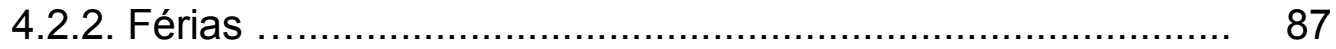

4.2.3. Gratificação natalina $\left(13^{\circ}\right.$ salário $)$................................. 93

4.2.4. Fundo de Garantia do Tempo de Serviço -FGTS ............... 97

4.2.5. Aviso prévio ....................................................... 98

4.2.6. Vantagens da categoria e direitos do contrato de trabalho ... 101

4.2.7. Extinção contratual ................................................... 109

4.2.7.1. Peculiaridades dos contratos a termo .................... 116

4.2.7.2. Efeitos da dispensa sem justa causa no curso da suspensão contratual ....................................... 121

4.2.8. Garantia de emprego ............................................ 125

4.2.8.1. Previsão em instrumento normativo ....................... 132

4.2.8.2. No contrato a termo ........................................ 134

4.2.8.3. Efeitos da dispensa sem justa causa no curso da garantia de emprego

4.3. Empregados em situações especiais ................................... 141

4.3.1. Em período de carência e portador de doença anterior à filiação previdenciária ......................................................

4.3.2. Aposentado ..................................................... 146

4.4. A alta previdenciária do empregado incapacitado para o trabalho ... 147

4.4.1. Responsabilidade da previdência social e do empregador ... 154

4.4.2. Efeitos da concessão retroativa de auxílio-doença e a implantação retroativa por ordem judicial

4.5. A reabilitação no contrato de trabalho e a garantia indireta de emprego 


\section{INTRODUÇÃO}

\section{Justificativa e importância do tema}

O presente estudo tem como objeto a análise da incapacidade laborativa temporária decorrente de doença e seus efeitos no contrato de trabalho.

Em que pese a existência de materiais publicados e decisões judiciais sobre o tema, pretende-se a sistematização jurídica de situações complexas vivenciada no cotidiano dos operadores do Direito, para o posicionamento adequado do tema no ordenamento jurídico.

Não raramente, o trabalhador/segurado incapacitado se depara com situações em que a doutrina vem denominando "limbo jurídico".

A complexidade da questão impõe algo, no mínimo, inusitado: o trabalhador formalmente empregado e, por consequência, segurado da previdência social permanece sem qualquer salário e/ou benefício previdenciário indispensáveis à sua sobrevivência.

Trata-se de verdadeiro paradoxo à evolução dos direitos sociais do trabalhador, sobretudo quando sua incapacidade laborativa se originou de acidente do trabalho ou doença ocupacional.

Estes problemas se somaram aos anteriormente existentes (incapacidade no curso do período de carência do benefício previdenciário, efeitos do reconhecimento retroativo do auxílio-doença, quer administrativamente, quer por ordem judicial; e a garantia de emprego após a eclosão da doença ocupacional, quando extinto o contrato de trabalho).

\footnotetext{
${ }^{1}$ GONÇALVES, Lilian. Aposentadoria por invalidez: análise crítica de seus efeitos no contrato de trabalho. p. 130. Disponível em: <http://www.teses.usp.br/teses/disponiveis/2/2138/tde-18022013112553/pt-br.php>; acesso em 08 dez 2014.
} 
Disso, necessário o estudo sobre a forma em que ocorre o reconhecimento da incapacidade laborativa no contrato de trabalho, bem como a sistematização de seus efeitos jurídicos .

A segurança jurídica do trabalhador e do empregador está extremamente comprometida diante da ausência de sistematização para estas questões.

O presente estudo tem a finalidade de compor essa sistematização jurídica aplicável à incapacidade laborativa, por meio do estudo histórico e normativo na proteção dos direitos sociais do empregado.

\section{Delimitação do tema}

Como anotado, a dissertação tem como objetivo a análise da incapacidade laborativa e seu reconhecimento concreto no contrato de trabalho, bem como a sistematização dos efeitos jurídicos da incapacidade temporária no contrato de trabalho trabalho decorrente de doença.

Saliente-se, de plano, que estão excluídas do objeto do presente trabalho a incapacidade indefinida ou indeterminada causadora da aposentadoria por invalidez.

Para efeitos de delimitação do presente estudo no âmbito do contrato de trabalho, a incapacidade temporária é aquela que se pode esperar recuperação dentro de prazo previsível e que ainda não houve o reconhecimento da incapacidade indefinida por meio da concessão de aposentadoria por invalidez pela previdência social. 
Com a finalidade de desenvolver esse objetivo, relevante a apresentação panorâmica da evolução histórica do instituto no contexto dos direitos sociais.

Será estudada pormenorizadamente a conceituação de incapacidade laborativa e a sua caracterização no contrato de trabalho, a análise dos aspectos gerais da suspensão e interrupção do contrato de trabalho, assim como os efeitos produzidos no contrato de trabalho.

Serão sistematizados os efeitos da incapacidade temporária no contrato de trabalho, consentâneos à análise dos institutos trabalhistas aplicados ao tema, em especial:

i) nova concepção da suspensão contratual na hipótese e a vigência das cláusulas do contrato de trabalho;

ii) impasse da alta do trabalhador pelo INSS e a incapacidade reconhecida pelo médico do trabalho/empregador, também responsável pela saúde do trabalhador;

iii) os efeitos do reconhecimento retroativo ao auxílio-doença, tanto na esfera administrativa, quanto judicial (destacando-se, quanto a esta, que a competência de órgãos jurisdicionais diversos pode acarretar em situações conflitantes); e

iv) os efeitos da eclosão de doença ocupacional após a extinção contratual.

Pode-se afirmar que a presente dissertação tem objetivo sistêmico no tratamento do tema, bem como dinâmico, para aproveitamento por toda a sociedade ao se deparar com as questões abordadas. 
Propugnam-se novas ideias alicerçadas nas origens, finalidades e debates doutrinários e jurisprudenciais sobre o tema, sem prejuízo do rigor necessário para a conclusão do trabalho científico. 


\section{CAPÍTULO 1}

\section{A EVOLUÇÃO HISTÓRICA DA INCAPACIDADE LABORATIVA}

\subsection{Evolução histórica no âmbito internacional}

A incapacidade laborativa sempre foi objeto de preocupação dos indivíduos, dizendo-se que há previdência necessária para custear essa cobertura.

$\mathrm{Na}$ antiguidade, em Roma, existiam os Collegia, instituições formadas por pessoas que exerciam o mesmo ofício e cobriam as necessidades derivadas da enfermidade de algum de seus membros:

Os collegia eram formados de todos aqueles que exerciam uma profissão fora de sua família. Os seus membros estavam ligados entre si pelo estatuto do collegium e se obrigavam solidariamente perante um terceiro. ${ }^{2}$

No início da idade média, as pessoas organizaram as Guildas, instituições de assistência médica mútua e solidária, cuja função era muito similar aos Collegia romanos. Nos feudos, em certa medida, os senhores eram responsáveis pelo serviço de saúde para seus servos.

Na baixa idade média ocorreu o nascimento das primeiras Confrarias, instituições de assistência mútua especialmente para casos de enfermidade ou morte e, posteriormente, as irmandades de socorro, precursoras das sociedades de socorros mútuos que realizaram essa função até a Revolução Francesa.

Marco histórico dessa época foi a Lei de Amparo aos Pobres (Poor Rilief Act), editada na Inglaterra em 1601, que regulamentou auxílio aos necessitados por meio de contribuições obrigatórias de quem estivesse em

${ }^{2}$ NÓBREGA, Vandick Londres da. História e Sistema do Direito Privado Romano. 1. ed. Rio de Janeiro: Freitas Bastos, 1959, p.137. 
condições de contribuir. Os juízes da Comarca poderiam nomear inspetores em cada uma das paróquias para receberem e aplicarem o montante arrecadado, gerido pelo Estado. ${ }^{3}$

Na América pré-colombina, a população indígena mais desenvolvida (incas e maias) conheceu importantes métodos de previdência:

Los incas dividían la tierra de cultivo em tres partes destinadas respectivamente a la família, la religión y la comunidad. Las tierras destinadas a la comunidad se distribuían entre las famílias, y una parte de ellas se trabajaba colectivamente para atender el sustento de los ancianos, inválidos, enfermos e viudas. ${ }^{4}$

Após a colonização espanhola passou-se a repetir o sistema de Confrarias adotado na Europa.

A partir da segunda metade do século XIX, os efeitos da Revolução Industrial se disseminavam na Europa: incremento da taxa de desemprego, arrocho salarial, elevação dos acidentes de trabalho ${ }^{5}$, degradação das condições de trabalho, miséria em grandes conglomerados urbanos, sentimento coletivo da classe trabalhadora e criação de associações, crise da responsabilidade compartilhada entre o trabalhador e a empresa ${ }^{6}$, entre outros.

O ano de 1848 é, de fato, marco decisivo à compreensão da História do Direito do Trabalho. Isso, pela verdadeira mudança que produz no pensamento socialista, representada pela publicação do Manifesto do Marx e Engels, sepultando a hegemonia, no pensamento revolucionário, das vertentes insurrecionais ou utópicas. Do mesmo modo, pelo processo de revoluções e movimentos de massa experimentado naquele instante, indicando a reorientação estratégica das classes socialmente subordinada. Estas passam a se voltar a uma linha de incisiva pressão coletiva sobre o polo adverso na relação empregatícias (o empresariado) e sobre a ordem institucional vigorante, de modo a insculpir no universo das condições de

\footnotetext{
${ }^{3}$ MARTINS, Sergio Pinto. Direito da Seguridade Social. 22. ed. São Paulo: Atlas, 2005.p. 29.

${ }^{4}$ FERREIRA, Tatiana, RODRIGUEZ Américo Plá. La seguridade social en el Uruguay. Montevideo: Fundación de Cultura Universitaria. 1984, p. 290.

${ }_{5}^{5}$ FELICIANO, Guilherme Guimarães. Curso Crítico de Direito do Trabalho. 1. ed. São Paulo: Saraiva, 2013, p.61.

6 CRUZ, Paulo Marcio. "Fundamentos Históricos, Políticos e Jurídicos da Seguridade Social". [In]: ROCHA, Daniel Machado da; SAVARIS, José Antonio (coord.). Curso de Especialização em Direito Previdenciário. v.1. Curitiba: Juruá, 2005, p. 21.
} 
contratação da força de trabalho e no universo jurídico mais amplo da sociedade o vigor de sua palavra e de seus interesses coletivos ${ }^{7}$.

Em 15 de junho de 1883, a Alemanha de Bismark instituiu o primeiro seguro-doença obrigatório (Krankenversicherung) do mundo, consistente na filiação obrigatória de trabalhadores com salário não superior a 2.000 marcos anuais, com contribuição de $2 \%$ a $3 \%$ dos salários, paga um terço pelos patrões e dois terços pelos empregados. Os benefícios consistiam em assistência médica e farmacêutica durante treze semanas, além de uma quantia em dinheiro igual à metade do salário do segurado.

No ano seguinte, em 6 de julho de 1884, foi instituído o seguro de acidente do trabalho (Unfallversicherung), que cobria todos os riscos do trabalho, salvo por dolo da vítima. A contribuição era exclusivamente patronal e os benefícios eram os mesmos do seguro-doença, além de pagamento de indenização em caso de morte ou incapacidade.

Esses seguros sociais são concebidos como a passagem do seguro privado, coletivo e facultativo para a previdência social, de contribuição compulsória.

A mudança de pensamento filosófico ocorrido nessa época é sintetizada da seguinte forma por Mario de La Cueva:

Como una de sus más bellas expressiones, la seguridad social lanzó la idéia de la responsabilidad de la economia, manifestación de uma nueva filosofia social, que postula el principio de que la vida, por solo el hecho de ser vida, tiene derecho a su seguridad presente y futura, a fin de que pueda desarrollarse libre y plenamente, uma nueva ordenación de los valores, porque, y parafraseamos na sentencia que se inspira em las enseñanzas medievales, no está el hombre ordenado a la economia, sino ésta a aquél, queiere decir, y coincidimos totalmente con el marxismo y com el pensamiento de sectores cada dia más numerosos de la Iglesia católica, en el conflicto histórico entre el trabajo y el capital, que aun subsiste, el primado corresponde al trabajo. Estas primeiras meditaciones nos autorizan a concluir que la seguridad social es uma idea ética, según da cual, los valores humanos, que son los valores éticos, prian

\footnotetext{
${ }^{7}$ DELGADO, Maurício Godinho. Curso de Direito do Trabalho. 5. ed. São Paulo: LTr, 2006, p. 95.
} 
sobre los valores de la economia, que son de natureza material. ${ }^{8}$ (grifos no original)

A partir da entrada do Século XX, consolidou-se a constitucionalização dos direitos sociais, originariamente na Constituição Mexicana de 1917 e na Constituição de Weimar em 1919.

No mesmo ano de 1919, como parte do Tratado de Versalhes, que pôs fim à Primeira Guerra Mundial, ocorre a criação da Organização Internacional do Trabalho - OIT a qual, com o passar dos anos, adotou diversas Convenções atinentes à incapacidade de trabalho:

a) a Convenção $n^{\circ}$ 3, de 29 de novembro de 1919 (ratificada pelo Brasil em 26/04/1934 e denunciada em razão da Convenção $n^{\circ} 103$ ), assegurou o afastamento do trabalho à mulher gestante por doze semanas (seis antes e seis após o parto), mediante a apresentação de atestado, com prestações suficientes para a sua manutenção, a serem arcadas pelo tesouro público em um sistema de seguro. Garantiu-se ainda o emprego da gestante por período superior ao anteriormente previsto, quando estivesse incapacitada por doença decorrente da gravidez ou parto, segundo atestado médico correspondente;

b) a Convenção $n^{\circ} 12$, de 12 de novembro de 1921 (ratificada pelo Brasil em 25/04/1957), estabelece compromisso de estender a todos os empregados agrícolas o benefício das leis e regulamentos destinados a indenizar as vítimas de acidente do trabalho;

c) as Convenções $n^{\circ}$ 17, 18 e 19, todas de 10 de junho de 1925 (a última ratificada pelo Brasil em 25/04/1957), garantem aos trabalhadores urbanos e rurais indenização em caso de acidente de trabalho seguido de morte ou em caso de incapacidade permanente, inclusive com remuneração adicional caso necessite de outra pessoa, bem como a assistência médica ao acidentado; essas 
garantias também albergavam as doenças ocupacionais e para nacionais de qualquer outro membro da OIT;

d) as Convenções n 24 e 25, ambas de 15 de junho de 1927, não ratificadas pelo Brasil, garantem aos trabalhadores urbanos, inclusive domésticos e rurais, seguro-enfermidade por 26 semanas para aqueles que estiverem incapazes de trabalhar em razão de doença, podendo ser admitida a existência de carência; trata-se da primeira norma internacional ${ }^{9}$ que estabelece a obrigatoriedade de seguro saúde para trabalhadores incapacitados para o trabalho, independentemente da origem da incapacidade (ocupacional ou não), em que pese excetuar sua aplicabilidade a diversas espécies, como os marítimos e pescadores; bem como estabelece a administração por instituições autônomas com a gestão participativa dos segurados, a necessidade de fonte de custeio por parte dos empregados e empregadores, além de remeter ao direito nacional sobre o custeio pelo Estado.

e) as Convenções n 37 e 38, ambas de 29 de junho de 1933, não ratificadas pelo Brasil, normatizam o seguro-invalidez para trabalhadores urbanos, inclusive domésticos e rurais, quando "uma incapacidade geral que lhe impeça de procurar trabalho com uma remuneração considerável"10, podendo se sujeitar à existência de carência;

f) a Convenção $n^{\circ}$ 42, de 21 de junho de 1934 (ratificada pelo Brasil em 08/06/1936), garante às vítimas de doenças profissionais indenização equivalente àquelas destinadas aos acidentes de trabalho; a norma estabelece ainda um quadro de doenças, substâncias tóxicas e atividade profissionais, segundo o qual os membros que a ratificarem se comprometem a reconhecê-las como doenças profissionais.

9 FERREIRA, Tatiana; PLÁ RODRIGUEZ, Américo. La seguridade social en el Uruguay. Montevideo: Fundación de Cultura Universitaria. 1984, p. 293.

${ }^{10}$ Artigo $4^{\circ}$ da Convenção OIT n ${ }^{\circ} 38$, de 08 de junho de 1933. 
g) as Convenções $n^{\circ} 55$ e $n^{\circ} 56$, de 24 de outubro de 1936, não ratificadas pelo Brasil, aplicam-se às incapacidades dos trabalhadores marítimos e pescadores, outrora excluídos da proteção das Convenções n 24 e nº 25.

h) a Convenção $n^{\circ}$ 102, de 28 de junho de 1952 (ratificada pelo Brasil em 15/06/2009), denominada "Convenção Concernente às Normas Mínimas para a Seguridade Social, 1952", sistematiza as garantias mínimas de proteção social no âmbito previdenciário, especificamente quanto à incapacidade para o trabalho: a) auxílio-doença (possibilitada a existência de carência, a limitação do benefício em 26 semanas e ausência de pagamento nos três primeiros dias da suspensão dos ganhos); b) prestações em caso de acidentes e doenças profissionais (possibilitada a limitação de $50 \%$ sobre o "total dos ganhos anteriores do beneficiário"); c) prestações por maternidade (possibilitada a limitação de pagamento em doze semanas, bem como a limitação a $45 \%$ sobre o "total dos ganhos anteriores do beneficiário"); e d) aposentadoria por invalidez (possibilitada a existência de carência e a limitação de $50 \%$ sobre o "total dos ganhos anteriores do beneficiário").

i) a Convenção no 103, de 28 de junho de 1952 (ratificada pelo Brasil em 18/06/1965), denominada "Convenção de Amparo à Maternidade (Revista) 1952, aplica-se às mulheres no trabalho urbano, rural e em domicílio; estabelece duração mínima de doze semanas e parte da licença será obrigatoriamente usufruída após o parto, nunca inferior a seis semanas; mediante atestado médico, a licença pré-parto ou doença corolário do parto poderá ser estendida; fixa prestações não inferiores a dois terços dos proventos anteriores; estabelece o cômputo das interrupções para aleitamento na duração do trabalho; considera "ilegal para seu empregador despedi-la durante a referida ausência ou data tal que o prazo do aviso prévio termine enquanto durar a ausência";

j) a Convenção $n^{\circ} 121$, de 08 de julho de 1964, não ratificada pelo Brasil, revisa as Convenções sobre acidentes de trabalho e doenças profissionais, 
garantidas minimamente assistência médica e prestações monetárias em razão da contingência;

k) a Convenção $n^{\circ}$ 128, de 29 de junho de 1967, não ratificada pelo Brasil, trata de prestações decorrentes da invalidez, considerada como a "incapacidade de exercer qualquer atividade remunerada, de um grau prescrito, quando provável que esta incapacidade será permanente ou quando subsista após o término de um período prescrito de incapacidade temporal ou inicial"; consistentes em serviços de readaptação profissional, medidas de colocação adequada dos trabalhadores e pagamento periódico enquanto durar a invalidez de $50 \%$ dos ganhos anteriores do beneficiário (no caso de trabalhador assalariado).

I) a Convenção $n^{\circ}$ 130, de 25 de junho de 1969, não ratificada pelo Brasil, revisa a Convenção $n^{\circ} 25$, estabelecendo a necessidade de assistência médica e prestações monetárias decorrentes de enfermidades, entendidas como estado mórbido, qualquer que seja sua causa;

m) a Convenção $n^{\circ}$ 157, de 21 de junho de 1982, não ratificada pelo Brasil, denominada "Convenção sobre a manutenção dos direitos à segurança social de 1982" elenca os ramos e forma de atuação dos Estados-membros em ramos da segurança social relacionados à incapacidade laborativa: assistência médica, auxílio-doença, maternidade, invalidez, acidente do trabalho e doenças profissionais;

n) a Convenção $n^{\circ}$ 159, de 20 de junho de 1983 (ratificada pelo Brasil em 18/05/1990), aborda a readaptação do trabalhador com deficiência, considerado como tal "um indivíduo cujas possibilidades de obter e conservar um emprego adequado e avançado na mesma são substancialmente reduzidas devido a uma deficiência física ou mental devidamente reconhecida", estabelecendo princípios da política de readaptação profissional, baseado no princípio da igualdade de oportunidades, bem como obrigando as autoridades 
competentes em tomar medidas para proteção, manutenção e progressão das pessoas com deficiência no mercado de trabalho;

o) a Convenção $n^{\circ} 165$, de 09 de outubro de 1987, não ratificada pelo Brasil, revisa as Convenções $n^{\circ} 55$ e 56, quanto ao regime de seguro social dos trabalhadores marítimos;

p) a Convenção $n^{\circ} 183$, de 15 de junho de 2000, não ratificada pelo Brasil, denominada "Convenção sobre a proteção da maternidade, 2000", que estende a licença maternidade de pelo menos 14 semanas e, em regra, estipula a licença de seis semanas após o parto. Esse diploma normativo inova ao proibir a dispensa da mulher grávida, durante a licença ou depois de seu retorno ao trabalho (de acordo com a legislação nacional); obriga a adoção de medidas que impeçam a discriminação no emprego em razão da maternidade, inclusive a proibição de teste de gravidez na admissão; e

q) a Convenção $n^{\circ} 184$, de 21 de junho de 2001, não ratificada pelo Brasil, estabelece normas sobre a seguridade e saúde para os trabalhadores da agricultura (não necessariamente empregados); especificamente quanto à incapacidade, garante a cobertura de acidente de trabalho, doenças ocupacionais, invalidez e outros riscos para a saúde associados ao trabalho, pelo menos de forma equivalente aos que beneficiam os trabalhadores em outros setores.

\subsection{Evolução histórica no âmbito nacional}

A evolução da proteção social no Brasil relativamente à incapacidade de trabalho em decorrência de doença ocorreu de forma semelhante à evolução internacional, na medida em que se iniciou da caridade e assistência mútua, de forma privada e facultativa, para depois passar ao seguro social obrigatório tal como previsto na Constituição de 1988. 


\subsubsection{Constituição de 1824}

A Constituição de 1824 apenas estabeleceu norma programática de socorros públicos aos cidadãos no artigo 179 , inciso $X X X I^{11}$, porquanto não houve regulamentação de tais socorros no ordenamento jurídico do império. ${ }^{12} \mathrm{Em}$ razão disso, a doutrina afirma que o preceito poderia ser classificado como assistencial, porquanto impunha dever genérico e de escassa efetividade. ${ }^{13}$

O artigo 79 do Código Comercial de 1850 garantia o pagamento de salários aos prepostos no período não superior a três meses quando sofressem acidentes "imprevistos e inculpados".

Outrossim, houve medidas legislativas esparsas atinentes à previdência social como: ${ }^{14} \mathrm{e}^{15}$

a) Decreto 2.711/1860, que regulou o financiamento de montepios e sociedades de socorros mútuos;

b) Lei 3.397/1888, que criou a "Caixa de Socorros" para os trabalhadores de estrada de ferro do Estado;

c) Decreto 9.212/1889, que instituiu o montepio obrigatório para os empregados dos Correios;

d) Decreto 10.269/1889, que criou o "Fundo de Pensões" do pessoal das oficinas da Imprensa Nacional;

\footnotetext{
${ }^{11}$ Artigo 179 da Constituição de 1824: "A inviolabilidade dos Direitos Civis, e Politicos dos Cidadãos Brazileiros, que tem por base a liberdade, a segurança individual, e a propriedade, é garantida pela Constituição do Imperio, pela maneira seguinte. XXXI. A Constituição tambem garante os soccorros publicos.

${ }_{12}$ GONÇALVES, Lilian. Aposentadoria por invalidez: análise crítica de seus efeitos no contrato de trabalho. GONÇALVES, Lilian. Aposentadoria por invalidez: análise crítica de seus efeitos no contrato de trabalho. Tese [Doutorado] apresentada ao Curso de Direito do Trabalho e Seguridade Social da Faculdade de Direito da Universidade de São Paulo, São Paulo, 2012, p.14. Disponível em: <http://www.teses.usp.br/teses/disponiveis/2/2138/tde-18022013-112553/pt-br.php>; acesso em 08 dez 2014.

13 TAVARES, Marcelo Leonardo. Previdência e assistência social: legitimação e fundamentação constitucional brasileira. Rio de Janeiro: Lúmen luris, 2003, p. 49.

${ }^{14}$ MARTINS, Sergio Pinto. Direito da Seguridade Social. 22. ed. São Paulo: Atlas, 2005, p.32.

${ }^{15}$ SÜSSEKIND, Arnaldo. Previdência Social Brasileira. Rio de Janeiro: Freitas Bastos, 1955, p. 61.
} 
e) Decreto 221/1890, que conferiu direito à aposentadoria para os empregados da Estrada de Ferro Central do Brasil, o que foi estendido a todos os ferroviários de empresas do Estado pelo Decreto 565/1890; e

f) Decreto 942-A/1890, que instituiu o montepio obrigatório para os empregados do Ministério da Fazenda.

A toda evidência, percebe-se que a legislação esparsa era direcionada para os trabalhadores do império e que não havia sistematização do ordenamento jurídico para proteção social dos trabalhadores de forma geral, porquanto a maior forma de utilização de mão-de-obra na época era a escrava, cuja abolição somente ocorreu em 13 de maio de 1888 pela Lei Imperial 3.353, conhecida como Lei Áurea.

\subsubsection{Constituição de 1891}

A Constituição de 1891 não disciplinou a ordem econômica social. Todavia, estabeleceu, pela primeira vez, a concessão de aposentadoria por invalidez aos funcionários públicos no serviço da Nação. ${ }^{16}$

Sob à égide dessa Constituição, destacam-se os seguintes diplomas normativos que trataram da incapacidade laborativa:

a) Decreto Legislativo $n^{\circ} 3.724$ de 15 de janeiro de 1919: regulou as obrigações decorrentes dos acidentes de trabalho e grau de incapacidade, ambos definidos com detalhes na norma; tarifou as indenizações devidas pelos empregadores; determinou a comunicação do acidente de trabalho imediatamente à autoridade policial, a qual remetia ao juízo competente o inquérito; ao receber o documento instaurava-se de ofício o processo judicial que deveria ser sentenciado em até 12 dias, ordenando-se o pagamento devido pelo acidente; classificou como privilegiado o crédito decorrente de acidente de trabalho; fixou a

${ }_{16}$ Artigo 75 da Constituição de 1891: "A aposentadoria só poderá ser dada aos funcionários públicos em caso de invalidez no serviço da Nação". 
nulidade de pleno direito qualquer convenção contrária à lei; classificou as incapacidades como total e parcial, bem como temporária ou permanente;

b) Decreto Legislativo $n^{0} 4.682$, de 24 de janeiro de 1923, conhecida como Lei Eloy Chaves: criou uma caixa de aposentadoria e pensão para cada empresa de estrada de ferro. Em relação à incapacidade laborativa, estabelecia a aposentadoria por invalidez para o funcionário, condicionada ao mínimo de 10 anos de serviço e exames dos médicos da caixa; no caso de invalidez decorrente de acidente de trabalho, não exigia período mínimo de carência; fixou o caráter provisório da aposentadoria por invalidez e vedou a concessão desse benefício aos requerimentos realizados "após ter deixado o serviço na empresa";

Posteriormente, o regime de caixas de aposentadoria e pensões foi estendido ao pessoal de outras empresas (Decreto $n^{\circ} 19.497$ de 17 de dezembro de 1930).

Paulatinamente, essas caixas foram reunidas em institutos (IAPs Institutos de Aposentadoria e Pensões) por categoria profissional, havendo a criação de diversas instituições nesse período ${ }^{17}$.

c) Decreto $\mathrm{n}^{\circ}$ 16.300, de 31 de dezembro de 1923: aprovou o Regulamento Nacional de Saúde Pública, garantindo à mulher gestante repouso de trinta dias antes e trinta dias após o parto, mediante atestado médico das empresas ou particular da gestante; e

d) Decreto $n^{\circ}$ 21.417-A, de 17 de maio de 1932: regulou o trabalho da mulher na indústria e comércio, estabelecendo a primeira garantia de emprego no Direito Brasileiro:

Art. 13. Aos empregadores não é permitido despedir a mulher grávida pelo simples fato da gravidez e sem outro motivo que justifique a dispensa.

17 Por exemplo: Decreto 21.763/32, Decreto 21.081/32, Decreto 22.872/33, Decreto 24.272/34, Decreto 24.273/34, Decreto 24.275/34, Decreto 24.615/34, Decreto 24.637/34, Decreto 24.747/34 e Decreto 24.784/34. 
Em que pese essas evoluções legislativas nessa época, nenhuma delas regulou os efeitos da incapacidade decorrente de doença no contrato de trabalho.

A solução para essa questão ${ }^{18}$, nessa chamada "fase civilista" do Direito do Trabalho no Brasil ${ }^{19}$, advinha do artigo 1229, I, do Código Civil de 1916, posteriormente alterado pelo Decreto Legislativo $n^{\circ} 3.725 / 19$, para o artigo 1229, III:

Art. 1.229. São justas causas para dar o locatario por findo o contracto:

III. Enfermidade ou qualquer outra causa que torne o locador incapaz dos serviços contractados.

Adiante poderá se verificar que, embora não representativa da justa causa, a suspensão contratual originada da incapacidade laborativa não impediu, por muito tempo, a rescisão contratual por iniciativa do empregador.

c) Decreto $n^{\circ} 24.637$, de 10 de julho de 1934: esta foi a segunda norma sobre acidente de trabalho no Brasil; passou a reconhecer como acidente as doenças não inerentes à atividade, mas resultante do trabalho; excluía a responsabilidade do empregador somente no caso de força maior ou dolo da vítima ou de terceiros, ou seja, não exigia o elemento culpa para a responsabilidade do empregador; e excetuava a aplicabilidade no âmbito o trabalho doméstico.

\subsubsection{Constituição de 1934}

A Constituição de 1934 constitucionaliza diversos direitos trabalhistas, mais especificamente em relação à incapacidade laborativa: a licença maternidade, a instituição de previdência com contribuição tripartide (União,

\footnotetext{
${ }^{18}$ Nesse sentido: SÜSSEKIND, Arnaldo Lopes; MARANHÃO, Délio; VIANNA, Segadas; TEIXEIRA, Lima. Instituições de Direito do Trabalho. 22. ed. São Paulo: LTr, 2005. Vol. II, p. 237.

19 FELICIANO, Guilherme Guimarães. Curso Crítico de Direito do Trabalho. 1. ed. São Paulo: Saraiva, 2013, p. 81.
} 
empregador e empregado) para cobertura das contingências de invalidez, maternidade e acidente de trabalho. ${ }^{20}$

Nesse período, merecem destaques dois diplomas normativos:

a) Decreto $n^{\circ}$ 54, de 12 de setembro de 1934: aprovou o Regulamento do Instituto de Aposentadoria e Pensões dos Bancários (IAPB), quando surgiu, pela primeira $v e z^{21}$, a "assistência pecuniária por motivo de impedimento do trabalho" em razão de doença verificada por junta médica indicada pelo instituto, para os afastamentos superiores a 30 dias e inferiores a um ano (a partir de um ano poderia ser aposentado por invalidez), equivalente à metade dos vencimentos do associado.

Essa norma foi seguida de outras tantas ${ }^{22}$ que conferiam o agora denominado auxílio-enfermidade para os empregados impossibilitados de trabalhar. Entretanto, a legislação era omissa sobre a remuneração do período de espera (considerado como tal o período entre a incapacidade para o trabalho e o recebimento do benefício previdenciário) e os efeitos do associado (segurado) perante o empregador. ${ }^{23}$

b) Lei $n^{\circ} 62$, de 5 de junho de 1935: considerado o primeiro diploma geral trabalhista do Brasil. A novidade dessa norma corresponde em impedir a dispensa do empregado em razão do serviço militar ou outro múnus público, considerando-o como se houvesse sido licenciado sem vencimentos, garantindo seu retorno ao trabalho após esse período (artigo $9^{\circ}$ ). Essa norma trata dos efeitos da suspensão do contrato de trabalho, de forma particularizada, o que

\footnotetext{
${ }^{20}$ Art .121 - A lei promoverá [...] $\S 1^{\circ}$ - A legislação do trabalho observará os seguintes preceitos, além de outros que colimem melhorar as condições do trabalhador: [...] h) assistência médica e sanitária ao trabalhador e à gestante, assegurando a esta descanso antes e depois do parto, sem prejuízo do salário e do emprego, e instituição de previdência, mediante contribuição igual da União, do empregador e do empregado, a favor da velhice, da invalidez, da maternidade e nos casos de acidentes de trabalho ou de morte.

${ }^{21}$ LINS, Edilberto Quintela Vieira. Incapacidade executiva de trabalho e contrato de emprego: direito do trabalho e previdência social. Imprenta: Rio de Janeiro: Forense, 1984, p. 9.

${ }^{22}$ Decreto 337/35, Lei 367/36 e Decreto 1.557/37.

${ }^{23}$ LINS, Edilberto Quintela Vieira. Op. Cit. p. 9.
} 
passou a ser adotada de forma geral posteriormente pela Consolidação das Leis do Trabalho - CLT.

\subsubsection{Constituição de 1937}

A Constituição de 1937 foi outorgada pelo golpe de Estado de 1937 capitaneada por Getúlio Vargas.

A preocupação com a incapacidade de trabalho limitou-se à norma programática que relegava às normas infraconstitucionais a regulamentação desse tema. ${ }^{24}$

Nessa época, houve uma tentativa frustrada de unificação dos institutos de previdência social, o Instituto de Serviços Sociais do Brasil - ISSB, a partir de estudo coordenado por João Carlos Vital, em 1943, em razão de forte resistência: a) das seguradoras privadas, para garantir reserva de mercado; b) das categorias profissionais que recebiam melhores benefícios e temiam suas reduções; c) dos funcionários dos institutos que pretendiam manter seus cargos; d) dos líderes sindicais e políticos que controlavam as instituições previdenciárias setorizadas; e e) pelo empresariado, que temiam os aumentos das contribuições e, por conseguinte, o custo da produção. ${ }^{25} \mathrm{O}$ Brasil somente veria essa unificação ocorrer em 1960.

No plano infraconstitucional, solucionou-se o problema do período de espera para a incapacidade originada na enfermidade:

a) Decreto-lei $n^{\circ} 2.122$, de 9 de abril de 1940, que reorganizou o Instituto de Aposentadoria e Pensões dos Comerciários (IAPC) e estabeleceu que

\footnotetext{
${ }^{24}$ Artigo 137: A legislação do trabalho observará, além de outros, os seguintes preceitos: [...] m) a instituição de seguros de velhice, de invalidez, de vida e para os casos de acidentes do trabalho; n) as associações de trabalhadores têm o dever de prestar aos seus associados auxílio ou assistência, no referente às práticas administrativas ou judiciais relativas aos seguros de acidentes do trabalho e aos seguros sociais.

${ }^{25}$ DELGADO, Ignácio Godinho. Previdência Social e mercado no Brasil: a presença empresarial na trajetória política social brasileira. São Paulo: LTR, 2001, p. 155.
} 
o auxílio-pecuniário por motivo de doença seria devido a partir do $31^{\circ}$ dia e que os primeiros 30 dias deveriam ser pagos pelo empregador. Nesse diploma normativo, também se garantiu o retorno ao trabalho ou, na recusa, considerada como dispensa sem justa causa:

\begin{abstract}
Art. 29. Salvo disposições especiais que venham a ser estabelecidas em lei sobre contrato de trabalho, incumbirá ao empregador o pagamento dos vencimentos do empregado, correspondentes aos dias de afastamento do serviço por doença, até ao $30^{\circ}$ (trigésimo).

Parágrafo único. O segurado, no gozo das prestações do segurodoença, que tiver alta, atestada pelo Instituto, terá o direito de voltar para o serviço, em situação idêntica à da época de seu afastamento, considerando-se como dispensa injusta, para os fins da legislação do trabalho, a recusa de sua readmissão pelo empregador respectivo.
\end{abstract}

Da mesma forma, garantiu-se o retorno ao trabalho do segurado aposentado por invalidez ou, diante da recusa, equiparou-se-a à dispensa sem justa causa:

Art. 30. O segurado, na percepção de aposentadoria por invalidez, que for julgado válido, terá direito ao aproveitamento no último estabelecimento em que haja trabalhado, em situação idêntica à da época de sua saida, equiparando-se à despedida injusta, para o efeito da legislação do trabalho, a recusa desse aproveitamento.

Em que pese a evolução normativa sobre a matéria, houve muitas controvérsias quanto às categorias profissionais que abrangia, havendo decisões judiciais que limitavam aos comerciários e outras que estendiam a todas as categorias profissionais, por utilização da analogia e equidade. ${ }^{26} \mathrm{~A}$ questão somente foi superada pelo Decreto-lei n 6.905, de 26 de setembro de 1944.

b) Decreto-lei $n^{\circ}$ 6.905, de 26 de setembro de 1944, dispôs sobre a concessão de auxílio pecuniário por motivo de enfermidade do empregado. Por meio desse diploma normativo, unificaram-se os prazos dos benefícios previdenciários por motivo de doença, a serem concedidos a partir do $16^{\circ}$ dia de afastamento (artigo $1^{\circ}$ ) e determinou que os pagamentos dos primeiros 15 dias

${ }^{26}$ CESARINO JÚNIOR, Antonio Ferreira. Consolidação das Leis do Trabalho. 4. ed. Rio de Janeiro: Liv. Freitas Bastos S.A., 1956 vol. 1, p. 553. 
deveriam ser realizados pelo empregador no montante de $2 / 3$ do salário do empregado (artigo $2^{\circ}$ ).

Esse diploma normativo ainda regulamentou como se daria a caracterização da incapacidade para o trabalho, na medida em que o afastamento deveria ser atestado por (artigo $2^{\circ}$, parágrafo único):

...médico de instituição de previdência social a que esteja filiado, por médico indicado pelo próprio empregador, por médico do sindicato a que pertença o empregado ou o empregador, ou, finalmente, em falta dêsses, por médico a serviço de repartição federal, estadual ou municipal, incumbida de assuntos de higiene ou saúde. ${ }^{27}$

Na vigência desse instrumento normativo algumas controvérsias foram instauradas:

i) a necessidade de o empregador pagar salários por afastamentos inferiores a 15 dias, porquanto a norma determinava pagamentos dos durante "os quinze primeiros dias". A jurisprudência do Tribunal Superior do Trabalho (TST) estancou o problema ao definir que os pagamentos também eram devidos nessas hipóteses ${ }^{28}$;

ii) a existência de ordem preferencial dos atestados médicos no diploma normativo. O TST também se pacificou no sentido de que não havia ordem preferencial dos atestados médicos previstos na norma:

\begin{abstract}
A Junta, aceitando atestado passado por médico de sindicato, mandou pagar o salário relativo aos dias de doença, sob o fundamento de que para comprovação da doença, nos termos do Decreto $\mathrm{n}^{\circ}$ 6.905, deve ser respeitada a ordem preferencial das entidades ali enumeradas. - Embargos recebidos para restabelecer a sentença de primeira instância. Como se infere do parágrafo único do art. $2^{\circ}$ do Decreto 6.905 , o legislador não quis estabelecer nenhuma preferência ou hierarquia entre os médicos fornecedores de atestados, exceptuando somente quanto aos médicos a serviço de repartição federal, estadual ou municipal. Não há nenhuma gradação entre os médicos fornecedores de atestados, podendo qualquer deles, válida e legalmente, passar os referidos atestados.
\end{abstract}

\footnotetext{
${ }^{27}$ Artigo $2^{\circ}$, parágrafo único, do Decreto-Lei 6.905, de 26 de setembro de 1944.

${ }^{28}$ Acórdão $3^{\mathrm{a}}$ Turma, RR 2.333/64, Rel. Min. Aldilio Tostes Malta.
} 
(Proc. 1.198/59, TST - Pleno, Rel. Maurício Lange, D.O., 13-1-61). ${ }^{29}$

iii) a necessidade de pagamento pelo empregador dos 15 primeiros dias diante de reiteração de afastamentos inferiores a 15 dias ou logo após o término do benefício. A jurisprudência do TST oscilava sobre o tema, ora rejeitando a distinção pelo intérprete ${ }^{30}$, ora compreendendo que o trabalhador não tinha direito a novo pagamento do salário pelo empregador. ${ }^{31}$

c) Decreto-Lei $n^{0} 5.452$, em $1^{\circ}$ de maio de 1943, a conhecida Consolidação das Leis do Trabalho (CLT).

Os efeitos da incapacidade no contrato de trabalho passaram a ser tratados pela primeira vez em uma norma geral trabalhista, delineando a suspensão do contrato de trabalho, em que pese os problemas de conceituação pelo uso das expressões "suspensão", "afastamento", "deixar de comparecer" e "licença não remunerada", objeto de críticas dos operadores do direito.

No objeto de nosso estudo, destacam-se as disposições dos artigos 471 e 476 da CLT, que tratam dos afastamentos e retornos dos empregados e que percebam auxílios decorrentes de enfermidade. Em razão de permanecerem vigentes, o estudo apurado dessas normas será realizado no decorrer do trabalho.

Ainda sob a égide dessa Constituição, a Portaria $\mathrm{n}^{\circ}$ DNPS-775-A, de 15 de maio de 1946, regulamentando o Decreto-Lei $n^{\circ} 7.835$, de 6 de agosto de 1945 (que estabelecia limites mínimos e máximos da prestação de auxílio pecuniário por motivo de doença), utilizou a denominação "auxílio-doença", que viria a se generalizar a partir de então. ${ }^{32}$

\footnotetext{
${ }^{29}$ BOMFIM, B. Calheiros. A CLT vista pelo Tribunal Superior do Trabalho, Rio de Janeiro: Edições Trabalhistas S/A, 1963, p. 213.

${ }^{30}$ Acórdão $3^{\mathrm{a}}$ Turma, Processo $n^{\circ} 5.198 / 54$, Rel. Min. Délio Maranhão.

${ }^{31}$ Acórdão Pleno TST, Processo no 2.626/53, Rel. Min. Caldeira Neto.

${ }^{32}$ LINS, Edilberto Quintela Vieira. Incapacidade executiva de trabalho e contrato de emprego: direito do trabalho e previdência social. Imprenta: Rio de Janeiro: Forense, 1984, p. 33.
} 
d) Decreto-lei $n^{\circ} 7.036 / 44$, que passou a regular o acidente de trabalho, ampliando seu conceito para incorporar concausas e o acidente in itinere na hipótese de transporte oferecido pelo empregador. Essa norma expressamente permitia a acumulação dos direitos acidentários com responsabilidade civil na hipótese de dolo ${ }^{33}$, o que foi equiparado à culpa grave do empregador. ${ }^{34}$

\subsubsection{Constituição de 1946}

A Constituição de 1946 procurou restaurar o quadro anterior ao autoritarismo de 1937.

Pela primeira vez, consignou que competia à União legislar sobre previdência social (artigo $5^{\circ}, \mathrm{XV}$, alínea "b"), permitido aos Estados legislar de forma suplementar. Possibilitou-se também que os Estados e Municípios instituíssem seus regimes próprios de previdência para seus servidores, o que viria a ser seguido na atual Constituição de 1988.

Ainda no âmbito constitucional, obrigou-se o empregador a manter seguro de acidentes de trabalho, bem como estabeleceu preceitos de previdência social, por meio de custeio tripartido. ${ }^{35}$

Em 26 de agosto de 1960 foi publicada a Lei $n^{\circ}$ 3.807, a conhecida Lei Orgânica da Previdência Social (LOPS). A "LOPS deu unidade ao sistema de previdência social" ${ }^{36}$ na medida em que unificou o direito previdenciário no país, o

\footnotetext{
${ }^{33}$ Artigo 31 do Decreto-lei $n^{\circ} 7.036 / 44$ : O pagamento da indenização estabelecida pela presente lei exonera o empregador de qualquer outra indenização de direito comum, relativa ao mesmo acidente, a menos que êste resulte de dolo seu ou de seus prepostos.

${ }^{34}$ Súmula 229 do STF (1963): A indenização acidentária não exclui a do direito comum, em caso de dolo ou culpa grave do empregador.

35 Artigo 157: A legislação do trabalho e a da previdência social obedecerão nos seguintes preceitos, além de outros que visem a melhoria da condição dos trabalhadores:

[...] XVI - previdência, mediante contribuição da União, do empregador e do empregado, em favor da maternidade e contra as conseqüências da doença, da velhice, da invalidez e da morte;

XVII - obrigatoriedade da instituição do seguro pelo empregador contra os acidentes do trabalho.

Brasil.

${ }^{36}$ MARTINS, Sergio Pinto. Direito da Seguridade Social. 22. ed. São Paulo: Atlas, 2005, p. 37.
} 
que passou a ser administrado também de forma unitária, em regra, com a criação do Instituto Nacional de Previdência Social (INPS), pelo Decreto-lei nº 72 , de 21 de novembro de 1966.

Em suma, passou a regulamentar os benefícios de incapacidade para o trabalho da seguinte forma:

a) auxílio-doença: carência de 12 meses; prestação de $70 \%$ do saláriode-benefício, acrescido de $1 \%$ por ano de contribuição, limitado a 90\%; devido a partir do $16^{\circ}$ dia de afastamento; o pagamento dos 15 primeiros dias de afastamento permaneceu sob encargo do empregador.

A regulamentação desse benefício pelo Decreto $n^{\circ} 48.959-A$, de 19 de setembro de 1960, inaugurou solução de antiga controvérsia quanto aos afastamentos sucessivos:

Art. 95. Durante os primeiros 15 (quinze) dias de afastamento do trabalho, por motivo de doença, incumbe à emprêsa pagar ao segurado o respectivo salário.

Parágrafo único. No caso de benefício conseqüente, comprovadamente, da mesma doença, com intervalo de alta inferior a 60 (sessenta) dias, pagos os 15 (quinze) dias iniciais, fica a emprêsa desobrigada de novos pagamentos com base no artigo, cabendo ao Instituto prosseguir na manutenção do benefício.

b) aposentadoria por invalidez: concedida após a percepção de 24 meses do auxílio-doença, mas não estava condicionada a isso; prestação de $70 \%$ do salário-de-benefício, acrescido de $1 \%$ por ano de contribuição, limitado a 100\%; caracterização a cargo da previdência social; posteriormente, estabeleceuse a carência de 12 meses (Decreto-lei $n^{\circ}$ 66, de 1966); fixou-se o prazo de 5 anos para verificação da capacidade laborativa com a consequente extinção imediata do benefício e, no caso de recuperação após 5 anos, uma gradativa redução até sua extinção definitiva.

Nessa mesma época foi promulgada a Lei 605, de 5 de janeiro de 1949, que dispõe sobre o repouso semanal remunerado e regulamentou a 
comprovação da doença no seu artigo $6^{\circ}, \S^{\circ}{ }^{37}$. Segundo entendimento majoritário, a norma ainda está vigente e, por essa razão, os limites de sua aplicabilidade será estudada mais adiante.

\subsubsection{Constituição de 1967 e EC n 1 de 1969}

A Constituição de 1967 e EC nº 1 de 1969 não inovaram em relação aos benefícios previdenciários originados na incapacidade para o trabalho.

No plano infraconstitucional pode-se destacar a ampliação dos benefícios previdenciários para o trabalhador rural, ocorrida com a criação do FUNRURAL pela Lei Complementar 11/71, bem como para os trabalhadores domésticos pela Lei $n^{\circ} 5.859 / 72$.

Sobre o FUNRURAL, cabe salientar que apenas garantiu a aposentadoria por invalidez ${ }^{38}$, equivalente a $50 \%$ do salário-mínimo, não cobrindo a incapacidade temporária para o trabalho.

Nessa época passou a viger a quarta lei acidentária no Brasil, o Decreto-lei $n^{\circ} 293$, de 28 de fevereiro de 1967, que vigorou apenas seis meses e atribuiu ao seguro de acidente um caráter exclusivamente privado, marcando um inegável retrocesso.

Não obstante, a Lei $n^{\circ} 5.316$, de 14 de setembro de 1.967, restaurou dispositivos do Decreto-lei $n^{\circ} 7.036 / 44$ e transferiu ao INPS o monopólio do seguro de acidente de trabalho.

\footnotetext{
${ }^{37}$ Artigo $6^{\circ}$, $\S 2^{\circ}$, da Lei $605 / 49$ : $\S 2^{\circ} \mathrm{A}$ doença será comprovada, mediante atestado de médico da emprêsa, ou por ela designado e pago, e na falta dêste, de médico da instituição de previdência social a que esteja filiado o empregado, de médico do Serviço Social da Indústria ou do Serviço Social do Comércio, de médico a serviço de repartição federal, estadual ou municipal incumbida de assuntos de higiene e saúde, ou, não existindo êstes na localidade em que trabalhar o empregado, de médico de sua escolha.

${ }^{38}$ Artigo $5^{\circ}$ da Lei Complementar 11/1971 - A aposentadoria por invalidez corresponderá a uma prestação igual à da aposentadoria por velhice, e com ela não acumulável, devida ao trabalhador vítima de enfermidade ou lesão orgânica, total e definitivamente incapaz para o trabalho, observado o princípio estabelecido no parágrafo único do artigo anterior.
} 
A Lei $n^{\circ}$ 6.367, de 19 de outubro de 1976, melhorou o conceito de acidente de trabalho e das concausas, além de equiparar doenças não indicadas pela Previdência Social, quando estivessem relacionadas com o serviço prestado. $^{39}$

\subsubsection{Constituição de 1988}

A Constituição de 1988 elencou a Seguridade Social como objetivo fundamental da República Federativa do Brasil (artigo $3^{\circ}$, IV e artigo 193), sistema que abrange as áreas da saúde, assistência e previdência social.

A universalidade de atendimento e cobertura passou a ser objetivo da seguridade social (artigo 194, parágrafo único, I), embora a participação do sistema previdenciário dependa de contribuição dos segurados na forma da lei.

Garantiu-se ainda a uniformidade e equivalência de benefícios entre trabalhadores urbanos e rurais (artigo 194, parágrafo único, II), acabando com a distorção inexplicável do sistema jurídico anterior.

Ainda sob a égide da atual constituição brasileira, foi criado o Instituto Nacional do Seguro Social pela Lei $n^{\circ} 8.209 / 90$, a quem incumbe "promover o reconhecimento de direito ao recebimento de benefícios administrados pela Previdência Social, assegurando agilidade, comodidade aos seus usuários e ampliação do controle social. ${ }^{40}$.

A Lei $n^{\circ} 8.212 / 91$ normatizou o custeio da previdência social e a Lei $n^{\circ}$ 8.213/91 estabeleceu as normas referentes aos benefícios previdenciários. Por estarem atualmente vigente, o presente estudo aprofundará os efeitos da incapacidade laborativa decorrente de doença no contrato de trabalho.

${ }^{39}$ OLIVEIRA, Sebastião Geraldo de. Indenizações por Acidente do Trabalho ou Doença Ocupacional. 3. ed. São Paulo: LTr, 2007. p. 37.

${ }^{40}$ Artigo $1^{\circ}$, Anexo I, do Decreto $n^{\circ} 7.556 / 2011$. 


\section{CAPÍTULO 2}

\section{A INCAPACIDADE LABORATIVA POR DOENÇA}

\subsection{Definição de incapacidade laborativa por doença}

No vernáculo da língua portuguesa, a incapacidade é "falta de capacidade; inaptidão"41. "falta de capacidade física ou intelectual" ${ }^{42}$; "inaptidão, insuficiência, inservibilidade" ${ }^{43}$. Especificamente, a incapacidade laborativa é inaptidão para o trabalho:

...a doença, de maneira em geral, envolve situações em que o trabalhador se encontra incapacitado de desempenhar seu trabalho, o que o obriga a se afastar de suas atividades laborais por determinado período. ${ }^{44}$

É a que impede a pessoa de exercer suas atividades profissionais. Pode decorrer de moléstia, como pode decorrer de acidente, havido mesmo no trabalho. ${ }^{45}$

A incapacidade para o trabalho está ligada a acontecimentos futuros e incertos e, por essa razão, identifica-se como risco biológico:

A perda da capacidade de trabalho tem que ver com os riscos biológicos que podem atingir qualquer ser humano: a doença, a invalidez, a velhice, o acidente (no trabalho ou não) e a morte. ${ }^{46}$

Há outros eventos que também desequilibram o orçamento doméstico, como o matrimônio, nascimento de filhos, que não são propriamente riscos, passaram a ser denominados contingências. "Essa nomenclatura, com o passar do tempo, passou a designar tanto os riscos como aqueles outros eventos,

${ }^{41}$ FERREIRA, Aurélio Buarque de Holanda. Novo dicionário Aurélio da língua portuguesa. 3. ed. Curitiba: Positivo, 2004, p. 1086.

${ }^{42}$ HOUAISS, Antônio; VILLAR, Mauro de Salles. Dicionário Houaiss da Língua Portuguesa. 1. ed. Rio de Janeiro: Objetiva, 2001, p. 1592.

${ }^{43}$ BUENO, Francisco da Silveira Bueno. Grande Dicionário Etimológico-Prosódico da Língua Portuguesa. 1. ed. São Paulo: Saraiva, 1965, p. 1184.

${ }^{44}$ WALDMAN, Tatiana Chang. "Doença". [In]: SCHWARZ, Rodrigo Garcia, 1971- (org.). Dicionário de direito do trabalho, de direito processual do trabalho, de direito previdenciário aplicado ao direito do trabalho. São Paulo: LTr, 2012. p. 393.

${ }^{45}$ SILVA, De Plácido e. Vocabulário Jurídico. 4. ed. São Paulo: Forense, 1975, p. 808.

${ }^{46}$ CARDONE, Marly A. Previdência Social e Contrato de Trabalho. Relações. Saraiva, 2011, p. 8. 
porquanto o que os identifica é o efeito deles sobre a capacidade econômica das pessoas" 47 :

Estos eventos, que pueden ser la maternidad, el desempleo, las cargas de família, la enfermedad, etc, son denominadas modernamente contingências sociales, y el estado de necessidade que provocan, debe ser atendido o reparado. ${ }^{48}$

Compreender o significado abstrato de incapacidade para o trabalho pode não exigir do intérprete um esforço mental muito apurado. Na atualidade, o entrave à efetivação dos direitos sociais decorrentes da incapacidade para o trabalho origina-se na sua caracterização concreta:

Assim como o indivíduo não se reduz ao trabalho, não se reduz a um aspecto médico. Diante do caso concreto, haverá ocasiões em que sabidamente há capacidade e ocasiões em que há incapacidade. Haverá, contudo, um enorme conjunto de situações em que essa certeza é improvável. ${ }^{49}$

Isso destaca que a aferição da incapacidade para o trabalho decorrente de doença está afeta não somente a aspectos objetivos, como a aspectos subjetivos a quem compete a análise da questão.

A aferição da incapacidade deve ser apurada em cada caso concreto, jamais em relação ao "segurado médio". ${ }^{50}$

A doutrina especializada reconhece que definir a incapacidade é uma tarefa difícil. ${ }^{51}$ Segundo Buono Neto e Buono ${ }^{52}$ :

A incapacidade para o trabalho se refere a qualquer redução ou falta (resultante de uma deficiência) da capacidade para exercer esta atividade dentro dos limites considerados normais para o ser humano. Complementando essa definição, relacionando a incapacidade e deficiência, quando não for evidenciada qualquer anormalidade

${ }^{47}$ CARDONE, Op. Cit., 2011, p.9.

${ }^{48}$ FERREIRA, PLÁ RODRIGUEZ, op. cit., 1984, p. 287.

49 TEIXEIRA, Eduardo Didonet. Considerações sobre o auxílio-doença e a aposentadoria por invalidez. Direito Federal: Revista da AJUFE. Brasília, a. 20, nº. 68, p. 143-56, out./dez. 2001, p. 154.

${ }^{50}$ VIANNA, João Ernesto Aragonés. Curso de Direito Previdenciário. São Paulo: LTr, 2007, p. 224.

${ }^{51}$ DANTAS, Rosa Amélia Andrade Dantas (Org.). Perícia Médica. Estabelecendo Nexo, Avaliando Danos e Constatando Incapacidade. São Paulo: LTr, 2010, p. 87.

${ }_{52}$ BUONO NETO, Antonio; BUONO, Elaine Arbex. Perícias judiciais na medicina do trabalho. 3. ed. São Paulo: LTr, 2008, p. 221. 
funcional sob o ponto de vista ocupacional, assim como não apresentando tal incapacidade para o desenvolvimento de suas atividades, não há incapacidade laborativa.

Geralmente são utilizados os critérios estabelecidos pela Previdência Social para concessão de benefícios por incapacidade como definidores da incapacidade laborativa, de acordo com o grau, à duração e à profissão desempenhada.

O Manual de Perícia Médica da Previdência Social conceitua, no Capítulo II, item $4.1^{53}$ :

4.1 - Incapacidade laborativa é a impossibilidade de desempenho das funções específicas de uma atividade ou ocupação, em conseqüência de alterações morfopsicofisiológicas provocadas por doença ou acidente.

4.1.1 - O risco de vida, para si ou para terceiros, ou de agravamento, que a permanência em atividade possa acarretar, será implicitamente incluído no conceito de incapacidade, desde que palpável e indiscutível.

No mesmo sentido, o Manual de Reconhecimento Inicial de Direitos, aprovado pela Resolução $n^{\circ}$ 258/PRES/INSS, de 14 de dezembro de 2012, também define incapacidade laborativa temporária, para efeitos de percepção do auxílio-doença, como ${ }^{54}$ :

Incapacidade laborativa é a impossibilidade de desempenho das funções específicas de uma atividade ou ocupação, em consequência de alterações psicológicas e fisiológicas provocadas por doença ou acidente e será definida pelo perito médico previdenciário - PMP.

Atualmente, percebem-se duas novas tendências na concepção da incapacidade para o trabalho: a) a contextualidade entre aptidão para o trabalho e funcionalidade dentro de um ambiente social; e b) a especialização dos parâmetros da perícia médica de acordo com cada doença.

\footnotetext{
${ }^{53}$ INSS - Instituto Nacional do Seguro Social. Manual de Perícia Médica da Previdência Social versão 2. p. 25. Disponível em: http://www.ieprev.com.br/userfiles/file/tabela\%20de\%20teto $\% 20$ inss/manualdepericiasmedicasdoINSS.pdf; acesso em $01 \mathrm{dez} 2014$;

${ }^{54}$ INSS - Instituto Nacional do Seguro Social. Manual de Reconhecimento Inicial de Direitos Volume IV. Auxílio-doença, auxílio-acidente, aposentadoria por invalidez e salário-maternidade. Dezembro/2012, p. 12. Disponível em: http://edgardconsultores.com/wpcontent/uploads/files/Manual_RI_Direitos-Dez-2012.pdf; acesso em 01 dez 2014;
} 


\section{Quanto à primeira tendência, a Organização Mundial de Saúde - OMS} desenvolveu a Classificação Internacional de Funcionalidade, Incapacidade e Saúde - CIF, de 2001. Para este instrumento a capacidade descreve a aptidão de um indivíduo para executar uma tarefa ou ação, em contexto com a funcionalidade:

O qualificador de capacidade descreve a aptidão de um indivíduo para executar uma tarefa ou uma acção. Este constructo visa indicar o nível máximo provável de funcionalidade que a pessoa pode atingir num dado domínio num dado momento. Para avaliar a capacidade plena do indivíduo, é necessário ter um ambiente "padronizado" para neutralizar o impacto variável dos diferentes ambientes sobre a capacidade do indivíduo. Esse ambiente padronizado pode ser: (a) um ambiente real, utilizado geralmente, para avaliação da capacidade em situações de teste; ou (b) nos casos em que isto não é possível, um ambiente que possa ser considerado como tendo um impacto uniforme. Este ambiente pode ser chamado de ambiente "uniforme " ou "padrão". Assim, a capacidade reflecte a aptidão do indivíduo ajustada ao ambiente. Este ajustamento deve ser o mesmo para todas as pessoas em todos os países para permitir comparações internacionais. As características do ambiente uniforme ou padrão podem ser codificadas utilizando-se a classificação dos Factores Ambientais. A diferença entre a capacidade e o desempenho reflecte a diferença entre os impactos do ambiente actual $e$ os do ambiente uniforme, proporcionando assim uma orientação útil sobre o que pode ser feito no ambiente do indivíduo para melhorar seu desempenho. ${ }^{55}$

Sobre esse ponto, a doutrina especializada ressalta a perspectiva positiva do enfoque realizado pela CIF, pois:

... substitui o enfoque negativo da deficiência e da incapacidade por uma perspectiva positiva, considerando as atividades que um indivíduo que apresenta alterações de função e/ou da estrutura do corpo pode desempenhar, assim como usa participação social. A funcionalidade e a incapacidade dos indivíduos são determinadas pelo contexto ambiental onde as pessoas vivem. ${ }^{56}$

\footnotetext{
${ }^{55}$ OMS - Organização Mundial de Saúde. CIF - Classificação Internacional de Funcionalidade, Incapacidade e Saúde. Lisboa, 2004.2 Disponível em: $<$ http://www.periciamedicadf.com.br/cif2/cif_portugues.pdf $>$; acesso em $04 \mathrm{dez} 2014$, p. 17.

${ }_{56}$ FARIAS, Norma; BUCHALLA, Cássia Maria. A classificação internacional de funcionalidade, incapacidade e saúde da organização mundial de saúde: conceitos, usos e perspectivas. Revista Brasileira de Epidemiologia. vol. 8. $n^{\circ}$. 2. São Paulo: junho/2005, p. 193.
} 
Todavia, "ela ainda não tem sua aplicabilidade metodologicamente esclarecida no tocante a estabelecer a relação entre o agravo à saúde, o ambiente de trabalho, e a incapacidade para o trabalho" 57

Essa nova concepção para recebimento de benefícios por incapacidade passou a ser adotada no âmbito da Lei Orgânica da Assistência Social (Lei 8.742/93) na atual redação do artigo $20, \S^{\circ}$ e $\S 6^{\circ}$, pela Lei 12.470/2011:

Art. 20. O benefício de prestação continuada é a garantia de um salário-mínimo mensal à pessoa com deficiência e ao idoso com 65 (sessenta e cinco) anos ou mais que comprovem não possuir meios de prover a própria manutenção nem de tê-la provida por sua família. ...

$\S 2$ ㅇ Para efeito de concessão deste benefício, considera-se pessoa com deficiência aquela que tem impedimentos de longo prazo de natureza física, mental, intelectual ou sensorial, os quais, em interação com diversas barreiras, podem obstruir sua participação plena e efetiva na sociedade em igualdade de condições com as demais pessoas.

$\S 6^{\circ}$ A concessão do benefício ficará sujeita à avaliação da deficiência e do grau de impedimento de que trata o $\S 2$, composta por avaliação médica e avaliação social realizadas por médicos peritos e por assistentes sociais do Instituto Nacional de Seguro Social - INSS.

Essa alteração legislativa passa a ser sistematizada com a aprovação do Manual de Procedimentos em Benefícios por Incapacidade, volume III, em junho de $2014^{58}$

\begin{abstract}
A partir da Lei 12.470 , de 31 de agosto de 2011, a incapacidade para o trabalho e para a vida independente deixou de ser critério de elegibilidade para o benefício, hoje centrado nos impedimentos de longo prazo de natureza física, mental, intelectual e/ou sensorial que, em interação com diversas barreiras acarretem limitações e restrições para o exercício de atividades e participação social, conforme a concepção ampliada de deficiência estabelecida pela Convenção da ONU..$^{59}$
\end{abstract}

${ }^{57}$ DANTAS, op. cit., 2010, p. 89.

${ }^{58}$ RESOLUÇÃO INSS/PRES $n^{\circ}$. 416, de 04 de junho de 2012. Aprova Diretrizes de Apoio à Decisão Médico-Pericial em Clínica Médica, Volume III - Parte do Manual de Procedimentos em Benefícios por Incapacidade. Disponível em: $<$ http://www010.dataprev.gov.br/sislex/paginas/72/INSS-PRES/2014/416.htm>; acesso em 05 dez 2014.

${ }^{59}$ INSS - Instituto Nacional do Seguro Social. Manual de Procedimentos em Benefícios por Incapacidade. Diretrizes de Apoio à decisão Médico-Pericial em Clínica Médica - Parte II HIVIAIDS, TUBERCULOSE e HANSENÍASE. Brasília/DF, Maio/2014, Volume III. p. 40. 
Não se pode olvidar que os benefícios da seguridade social (da LOAS e os benefícios previdenciários por incapacidade) estão afetos à perícia médica do Instituto Nacional do Seguro Social - INSS.

Essa constatação fática passa a ter relevância para nosso estudo, na medida em que os Manuais de Perícia Médica do INSS são padronizações para concessão de benefícios da previdência e assistência social.

Nesse contexto, a própria incapacidade para o trabalho por doença ganha novos contornos que não relacionados à questão fisiológica da doença. Agrega-se o contexto de participação social do trabalhador no ambiente de trabalho:

Fatores de ordem pessoal e barreiras psicossociais, sobretudo envolvendo estigma e discriminação, podem levar à incapacidade temporária ou mesmo definitiva, na dependência de sua magnitude, da atividade exercida e do contexto de vida de cada indivíduo. ${ }^{60}$

Em que pese tal aspecto estar difundido na previdência social para doenças de conhecido caráter estigmático (HIVIAIDS e Hanseníase), é certo que - fundamento primário admitido pela autarquia previdenciária para essa conclusão é o disposto no artigo $3^{\circ}$, IV, da Constituição Federal, que impede quaisquer formas de discriminação e, por consequência, deve ser estendido para a conceituação de incapacidade originada por qualquer outra doença.

Quanto à segunda tendência, necessário destacar que os novos manuais de procedimentos em benefícios por incapacidade passam a tratar as doenças de forma especializada, consubstanciando-se em elementos de natureza técnica (com apoio de profissionais internos e especialistas em cada doença) democraticamente implementados (por meio de consultas públicas para participação dos demais membros sociais).

Disponível em <http://www3.dataprev.gov.br/sislex/paginas/77/MANUAL_BENEFICIO/res416.pdf>; acesso em 01 dez 2014.

${ }^{60}$ INSS, op. cit., 2014, vol. III, p.33. 
Frutos dessa nova tendência são os Manuais de Procedimentos em Benefícios por Incapacidade aprovadas pelas Resoluções INSS/PRES N 128, de 16 de dezembro de $2010^{61}$ e INSS/PRES N 416, de 04 de junho de $2014^{62}$.

Por fim, saliente-se que a incapacidade para o trabalho pode-se apresentar em graduação parcial, ou seja, há situações em que existe a ausência de aptidão plena para o trabalho ou determinada atividade, de modo implicar: a) a redução da capacidade para o trabalho habitualmente prestado; e b) a redução da capacidade para o trabalho habitualmente prestado e exija maior esforço para o desempenho dessa atividade.

Em ambos os casos, o trabalhador está apto para o trabalho, mas de forma reduzida, porque sua capacidade laborativa não mais pode ser desenvolvida plenamente. Trata-se, pois, de uma inaptidão parcial para o trabalho.

Saliente-se que a redução da capacidade laborativa não é tratada pela doutrina, nem mesmo pela previdência social, na conceituação do fenômeno jurídico "incapacidade para o trabalho".

A doutrina especializada, corretamente, distingue o déficit funcional (incapacidade parcial) com a incapacidade laborativa:

Deficiência (ou déficit) é toda perda ou anormalidade de uma estrutura ou função psicológica, fisiológica ou anatômica, podendo ser temporária ou permanente, alterando o estado de saúde do indivíduo...

Incapacidade é a redução ou impossibilidade de realizar uma tarefa específica (laboral ou social) e pode-se classificar em diferentes

\footnotetext{
${ }^{61}$ Aprova o Manual de Procedimentos de Benefícios por Incapacidade (MPBI) : Diretrizes de Apoio à Decisão Médico-Pericial em Ortopedia e Traumatologia, Volume I, 2008. Disponível em: http://www3.dataprev.gov.br/sislex/paginas/72/INSS-PRES/2010/128.htm; acesso em 06 dez 2014; ${ }^{62}$ Aprova Diretrizes de Apoio à Decisão Médico Pericial em Clínica Médica - Volume III - Parte II do Manual de Procedimentos em Benefícios por Incapacidade. HIVIAIDS, Tuberculose e Hanseníase. Disponível $<$ http://www3.dataprev.gov.br/sislex/paginas/77/MANUAL_BENEFICIO/res416.pdf>; acesso em 01 dez 2014.
} 
graus. A incapacidade afeta tanto em nível funcional ou situação do dano. O conceito de incapacidade ou discapacidade é diferente do conceito de deficiência e é aplicado àquelas pessoas que, devido ao fato de possuírem alguma deficiência, apresentam limitações para o desempenho de algumas das atividades da vida diária. A incapacidade ou redução da capacidade laboral é uma limitação para uma tarefa específica em consequência a uma deficiência.

O que temos então são dois conceitos distintos, mas que se completam. No âmbito da justiça do trabalho, trabalhadores que apresentam uma doença ocupacional ou uma sequela de acidente de trabalho, tem por certo um déficit funcional, mas não uma incapacidade laboral. ${ }^{63}$

Essa diferenciação passa a ser muito importante no presente estudo, para fins de se aprofundar sobre os efeitos da incapacidade total e parcial no contrato de trabalho.

Por sua vez, em sentido oposto, a capacidade laborativa:

É a condição física e mental para o exercício de atividade produtiva. É a expressão utilizada para habilitar o examinado e desempenhar as atividades inerentes ao cargo ou função. $O$ indivíduo é considerado capaz para exercer uma determinada atividade ou ocupação quando reúne as condições morfopsicofisiológicas compatíveis com o seu pleno desempenho. A capacidade laborativa não implica ausência de doença ou lesão. Na avaliação da capacidade deve ser considerada a repercussão da doença ou lesão no desempenho das atividades laborais ${ }^{64}$.

Assim, a partir dos elementos acima destacados, pode-se afirmar que a incapacidade para o trabalho é a contingência social em que o indivíduo está inapto de desenvolver plenamente suas atividades laborais em razão de alterações morfopsicofisiológicas provocadas por doença ou acidente, contextualizadas no seu ambiente de trabalho.

\subsection{Classificação da incapacidade}

A classificação no Direito tem a finalidade de sistematizar metodologicamente um fenômeno jurídico segundo critério escolhido pelo

${ }^{63}$ PENTEADO, José Marcelo de Oliveira. Deficiência funcional vs. incapacidade laboral. LTR SUPLEMENTO TRABALHISTA. São Paulo, a. 50, nº 94, p. 434, 2014.

${ }^{64}$ GIMENES, Mara Aparecida. Incapacidade laboral e benefício por auxílio-doença no INSS. 1. ed. São Paulo: Ltr, 2014, p.18. 
estudioso. Não pode prevalecer sobre o conteúdo de sua pesquisa, sob pena de ele ser compartimentado e classificado à exaustão, sem qualquer utilidade científica.

No objeto do presente estudo, a classificação da incapacidade laborativa se revela necessária, não somente por contribuir para a maior compreensão de seu conceito, mas, principalmente, para analisar a extensão de seus efeitos no contrato de trabalho.

Outrossim, o presente estudo pretende abordar tão somente os efeitos decorrentes da incapacidade temporária no contrato de trabalho. Esse dimensionamento, portanto, passa a ser indispensável.

Não se pode deixar de recordar a existência de críticas por parte da doutrina sobre as classificações da incapacidade ${ }^{65}$. Não obstante, percebe-se a evolução dessas classificações em consentâneo aos benefícios previdenciários por incapacidade previstos no ordenamento jurídico.

A definição de incapacidade deve ser analisada quanto ao grau, à duração e à profissão desempenhada. ${ }^{66}$

\subsubsection{Quanto ao grau}

Quanto ao grau, a incapacidade laborativa, segundo a classificação doutrinária, pode ser parcial ou total:

a) será considerado como parcial o grau de incapacidade que ainda permita o desempenho de atividade, sem risco de vida ou agravamento maior e que seja compatível com a percepção de salário aproximado daquele que o interessado auferia antes da doença ou acidente;

${ }^{65}$ BATISTA, Flávio Roberto. Benefícios previdenciários por incapacidade no regime geral de previdência social. Dissertação [Mestrado]. São Paulo: Universidade de São Paulo, 2008, p. 128.

${ }^{66}$ Adotada a classificação do Manual de Perícia Médica da Previdência Social. 
b) será considerada como total a incapacidade que gera a impossibilidade de permanecer no trabalho, não permitindo atingir a média de rendimento alcançada, em condições normais, pelos trabalhadores da categoria do examinado.

A jurisprudência do Superior Tribunal de Justiça é clara no sentido de que não havendo distinção na lei sobre o grau de incapacidade, não cabe ao intérprete fazê-lo, sendo devido o auxílio-doença respectivo em ambas as situações ${ }^{67}$ :

RECURSO ESPECIAL. PREVIDENCIÁRIO. LEI 8.213/91. CONCESSÃO. AUXÍLIO-DOENÇA. INCAPACIDADE. TOTAL. PARCIAL.

A Lei 8.213/91 não faz distinção quanto à incapacidade, se deve ser total ou parcial; assim, não é possível restringir o benefício ao segurado, deferindo-o, tão-somente, quando a desventurada incapacidade for parcial. Recurso desprovido.

A partir dessa premissa jurisprudencial, a Advocacia Geral da União editou a Súmula 25:

SÚMULA N 25, DE 09 DE JUNHO DE 2008

"Será concedido auxílio-doença ao segurado considerado temporariamente incapaz para o trabalho ou sua atividade habitual, de forma total ou parcial, atendidos os demais requisitos legais, entendendo-se por incapacidade parcial aquela que permita sua reabilitação para outras atividades laborais."

Nesse ponto, a explanação crítica de Flávio Roberto Batista ${ }^{68}$ :

A lei não alberga o conceito de incapacidade parcial, até porque, quando pretendeu falar no que é habitualmente chamado de "incapacidade parcial", preferiu a expressão "redução da capacidade", como se pode verificar no artigo 86 da Lei 8.213/91. Existe apenas uma referência ao termo "incapacidade parcial", feita ao tratar a lei do serviço de reabilitação profissional.

Assim sendo, toda vez que a lei falar em incapacidade, é a "incapacidade total" que ela se refere. Caberá ao aplicador da lei, seja - Poder Judiciário, seja o INSS, definir, em cada caso, se as enfermidades do segurado são substanciais a ponto de determinarIhe a incapacidade ou se o mesmo pode trabalhar, inexistindo graus a

${ }^{67}$ STJ, REsp no 501276/SP, DJ de 28.06.2007, p. 427. Disponível em: <http://stj.gov.br>. Acesso em 03/12/2014.

${ }^{68}$ BATISTA, op. cit., 2008, p. 129. 
esse respeito, ao menos no que tange ao auxílio-doença e à aposentadoria por invalidez. Ou o segurado pode exercer sua atividade habitual, ou não pode. Não é possível exercê-la em parte. Ou o segurado pode ser reabilitado para outra atividade, ou não pode. Igualmente, não existe, reabilitação parcial.

Isso porque a sistemática previdenciária para concessão de benefício do auxílio-doença exige que o segurado esteja "incapacitado para o seu trabalho" (artigo 59 da Lei 8.213/91 e, após a MP 664/2014, artigo 60, caput, da Lei 8.213/91). Por óbvio, o dispositivo trata da incapacidade total, que gera impossibilidade de permanecer no trabalho para sua atividade habitual.

A incapacidade parcial, outrora chamada de "incapacidade relativa" equivale à redução da capacidade laborativa, mas não impede o desempenho da atividade do trabalhador (trata-se de déficit funcional) e está albergada pelo auxílio-acidente (artigo 86 da Lei 8.213/91).

A Súmula 25 da AGU confunde, sem dúvidas, as classificações da incapacidade, porque se utiliza do critério de classificação segundo o grau misturado com o critério de classificação segundo a profissão, ao afirmar que entende-se "por incapacidade parcial aquela que permita sua reabilitação para outras atividades laborais".

Ora, a possibilidade de reabilitação para outras atividade laborais demonstra que a incapacidade era uniprofissional (como estudaremos a seguir) e nada se relaciona com seu grau, porquanto, se a incapacidade impedir o trabalho ou atividade habitual, ela é total.

\subsubsection{Quanto à duração}

Quanto à duração a incapacidade laborativa pode ser temporária ou de duração indefinida ${ }^{69}$ :

${ }^{69}$ Despreza-se completamente o termo "incapacidade permanente", quanto à duração da incapacidade. A evolução da Medicina é surpreendente e não mais admite esse termo. Observese, por exemplo, publicação da Nature, em que se descobriu que a entrega sistêmica de certo péptido facilitou a recuperação funcional locomotora e urinária de ratos com a coluna espinhal lesionada. Novos caminhos em busca de recuperação da paraplegia. 
a) considera-se temporária a incapacidade para a qual se pode esperar recuperação dentro de prazo previsível;

b) a incapacidade indefinida é aquela insuscetível de alteração em prazo previsível com os recursos da terapêutica e reabilitação disponíveis à época.

Ponto crucial a ser analisado, por ser objeto da denominação do presente trabalho, é a inexistência de critério temporal para aferir se a incapacidade ainda é temporária.

Como bem destaca Hélio Gustavo Alves ${ }^{70}$ :

É cediço que o auxílio-doença pode ser convertido em aposentadoria por invalidez, porém, hodiernamente, ocorre por deliberalidade única e exclusiva do médico perito do INSS, pois não há critério temporal para haver a conversão.

Por falta de critério temporal é que segurados permanecem anos e anos recebendo auxílio-doença, sendo que poderiam estar aposentados por invalidez.

Para nosso estudo, sem adentrar na postura da previdência social, a incapacidade temporária é aquela que se pode esperar recuperação dentro de prazo previsível e que ainda não houve seu reconhecimento como incapacidade indefinida por meio de concessão da aposentadoria por invalidez pela previdência social.

Ao se tratar da previsibilidade da incapacidade laborativa também se faz necessário mencionar brevemente sobre o COPES (Cobertura Previdenciária Estimada), atualmente denominado DCB (Data de Cessação do Benefício), usualmente conhecido como alta programada.

\footnotetext{
NATURE - INTERNATIONAL WEEKLY JOURNAL OF SCIENCE. Incapacidade Permanente. Disponível em: <http://www.nature.com/nature/journal/vaop/ncurrent/full/nature13974.html>; acesso em $03 \mathrm{de}$ dezembro de 2014.

${ }^{70}$ ALVES, Hélio Gustavo. Conversão do auxílio-doença em aposentadoria por invalidez. Revista da Previdência Social, a. 37, n. 387, p. 110
} 
A redação original do artigo 78 do Decreto $3.048 / 99$, que regulamenta a Lei 8.213/91, previa que:

Art. 78. O auxílio-doença cessa pela recuperação da capacidade para o trabalho, pela transformação em aposentadoria por invalidez ou auxílio-acidente de qualquer natureza, neste caso se resultar seqüela que implique redução da capacidade para o trabalho que habitualmente exercia.

O procedimento adotado pela autarquia previdenciária era a concessão de auxílio-doença por prazo indeterminado com realização de perícias periódicas até a constatação da recuperação da capacidade de trabalho laborativa.

A partir da Orientação Interna Conjunta ${ }^{71} n^{0} 01$ Dirben/PFE, de 13 de setembro de 2005, o INSS passou a adotar procedimento diferente: na realização da perícia para a concessão do benefício o perito-médico fixava imediatamente a data futura de retorno ao trabalho. Trata-se da chamada alta programada ou data certa.

\begin{abstract}
Na prática, a alta programada dá-se da seguinte forma: o trabalhador passa por uma perícia na qual o médico confronta o código da enfermidade ou lesão diagnosticada com o tempo estimado de permanência em gozo do benefício apresentado pelo programa de computador utilizado pela autarquia e que se baseia em estudos estatísticos de diagnóstico, tratamento e tempo de recuperação de milhares de benefícios concedidos, sendo lançado no sistema informatizado do INSS a data de alta do segurado e o conseqüente encerramento do benefício. ${ }^{72}$
\end{abstract}

Essa alteração foi expressamente adotada com a edição do Decreto $n^{\circ}$ 5.844 , de 13 de julho de 2006, que incluiu os seguintes parágrafos no artigo 78 do Decreto 3.048/99:

§1으 O INSS poderá estabelecer, mediante avaliação médico-pericial, o prazo que entender suficiente para a recuperação da capacidade para

\footnotetext{
71 INSS - Instituto Nacional de Seguro Social. Diretoria de Benefícios. Procuradoria Federal Especializada. Orientação Interna Conjunta No 01 DIRBEN/PFE, de 13 de Setembro de 2005.

72 OLIVEIRA, Marcel Thiago de. Alta programada: afronta ao princípio da dignidade da pessoa humana. Jus Navigandi, Teresina, ano 14, n. 2151, 22 maio 2009. Disponível em: <http://jus.com.br/artigos/12882>. Acesso em: 5 dez. 2014.
} 
o trabalho do segurado, dispensada nessa hipótese a realização de nova perícia.

$\S 2^{\circ}-$ Caso o prazo concedido para a recuperação se revele insuficiente, o segurado poderá solicitar a realização de nova perícia médica, na forma estabelecida pelo Ministério da Previdência Social.

§3으 O documento de concessão do auxílio-doença conterá as informações necessárias para o requerimento da nova avaliação médico-pericial." (NR)

A chamada alta programada passou a nortear todas as análises de doenças para a concessão do benefício auxílio-doença. A própria especialização da medicina propicia análise técnica mais apurada sobre o período de afastamento referente a determinada doença.

Os novos Manuais de Procedimento em Benefícios por Incapacidade da previdência social, anteriormente mencionados, passaram a tratar a análise da doença de forma especializada e todos eles contêm os períodos de afastamento pré-definidos (tempo padrão) de acordo com conclusão do médico perito previdenciário.

O Tempo Padrão é o tempo estimado para benefício de auxíliodoença, que se requer para resolução de um processo clínico ou cirúrgico, que tenha originado incapacidade para o trabalho habitual. Utilizam-se técnicas de diagnóstico e tratamento normatizados e aceitos na comunidade médica. ${ }^{73}$

Isso significa que a subjetividade necessária para a análise da capacidade laborativa do empregado no contexto de seu ambiente de trabalho passou a ser simplificada por aplicações de tabelas com prazos de afastamentos previamente estabelecidos.

Há inúmeras discussões judicias sobre a legalidade desse procedimento, destacando-se ${ }^{74}$ a ação civil pública n 2005.33.00.020219-8 (nova

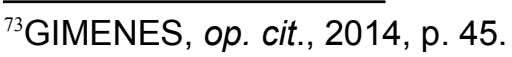

${ }^{74}$ A importância dessa ação civil pública decorre de sua abrangência nacional e ter sido reconhecida a conexão e respectiva prevenção dessa Vara pelo Superior Tribunal de Justiça no Conflito de Competência $n^{\circ}$ 64732/BA. Não obstante, suspendeu todas as liminares proferidas em tutela coletiva no país inteiro.
} 
numeração 0020207-73.2005.4.01.3300), da 14 ${ }^{\mathrm{a}}$ Vara Federal de Salvador, que decidiu:

\begin{abstract}
Julgo parcialmente procedente o pedido para determinar ao INSS que, no procedimento de concessão do benefício de auxílio-doença, inclusive aqueles decorrentes de acidente do trabalho, uma vez apresentado pelo segurado pedido de prorrogação, mantenha o pagamento do benefício até o julgamento do pedido após a realização de novo exame pericial.
\end{abstract}

A apelação está pendente de julgamento no TRF da $1^{\text {a }}$ Região desde 22/11/2010. Em 04/12/2014, o recurso foi redistribuído ao Des. João Luiz de Sousa. Em 2015, o processo coletivo completa 10 anos no Poder Judiciário, verdadeira vergonha nacional.

Para nosso estudo, deve-se obtemperar que a incapacidade temporária definida como a que "se pode esperar recuperação dentro de prazo previsível", ao menos para efeitos previdenciários, foi levada à literalidade pela alteração normativa da previdência social, na medida em que o prazo previsível se tornou "data certa".

Ao segurado restou requerer o pedido de prorrogação (artigo 78, §2 do Decreto 3.048/99) no prazo de 15 dias que antecede a cessação do benefício previdenciário (artigo 304, §2 , I, da Instrução Normativa INSS/PRES № 77, de 21 de janeiro de 2015), caso o prazo fixado para a alta seja insuficiente para a recuperação da capacidade para o trabalho.

Surge, então, o primeiro grande problema para a subsistência do trabalhador: a autarquia previdenciária não tem estrutura para atender a perícia médica em prazo tão exíguo.

Grande problema também era a interrupção do pagamento dos benefícios nos casos de pedido de prorrogação, tendo em vista o curto prazo para sua interposição (15 dias antes do término do benefício) e a impossibilidade do INSS de realizar a nova perícia dentro desse prazo. ${ }^{75}$

75 KRAVCHYCHYN, Gisele Lemos. Do direito a continuidade de pagamento em casos de pedido de prorrogação do benefício de auxílio doença. Jus Navigandi, Teresina, ano 18, $n^{\circ}$. 3769, 26 out. 
Não somente isso. O retorno ao trabalho não se realiza automaticamente. A recuperação da capacidade para o trabalho prevista na perícia da concessão do benefício previdenciário ainda passa sob o crivo do médico do trabalho, o que será tratado mais adiante.

Em sentido oposto, a incapacidade indefinida (recorde-se que abandonada a classificação de incapacidade permanente, por impropriedade do termo), consubstancia-se naquela em que é "insuscetível de alteração em prazo previsível com os recursos da terapêutica e reabilitação disponíveis à época".

À evidência, o que diferencia a incapacidade temporária e indefinida é a previsibilidade de recuperação da capacidade de trabalho. Por óbvio, isso deve ser considerado em uma sociedade, em determinada época, em razão da evolução da ciência médica e do acesso assegurado à população.

Assim, natural que doenças como a hanseníase, que outrora era tratada como incapacidade indefinida e de segregação compulsória vitalícia, atualmente é tratada como incapacidade temporária e a segregação se limita ao período de possível contágio (menos de um mês após o início da medicação própria) ou do grau de comprometimento funcional pela evolução da doença.

Em nosso trabalho, abordaremos apenas os efeitos da incapacidade temporária no contrato de trabalho que, embora possam coincidir com os da incapacidade indefinida, não são necessariamente equivalentes.

\subsubsection{Quanto à profissão}

Finalmente, adota-se a classificação da incapacidade segundo a profissão, que pode ser: 
a) uniprofissional - aquela em que o impedimento alcança apenas uma atividade específica;

b) multiprofissional - aquela em que o impedimento abrange diversas atividades profissionais;

c) omniprofissional - aquela que implica a impossibilidade do desempenho de toda e qualquer atividade laborativa, sendo conceito essencialmente teórico, salvo quando em caráter transitório.

A incapacidade uniprofissional é suficiente para produzir efeitos no contrato de trabalho em que exercida a respectiva atividade para qual 0 trabalhador se incapacitou.

Isso porque é possível que o trabalhador exerça mais de uma atividade, em contratos de trabalho diversos. Por exemplo: o trabalhador é enfermeiro durante o dia e professor à noite. Se a incapacidade atingir apenas uma atividade profissional, apenas sobre essa será concedido o afastamento por incapacidade e não afetará o contrato de trabalho referente a outra atividade.

Não obstante a omissão legislativa específica a essas situações, o Decreto 3.048/99 a previu expressamente:

Art. 73. O auxílio-doença do segurado que exercer mais de uma atividade abrangida pela previdência social será devido mesmo no caso de incapacidade apenas para o exercício de uma delas, devendo a perícia médica ser conhecedora de todas as atividades que o mesmo estiver exercendo.

§1ㅇNa hipótese deste artigo, o auxílio-doença será concedido em relação à atividade para a qual o segurado estiver incapacitado, considerando-se para efeito de carência somente as contribuições relativas a essa atividade.

§2ํㅡe nas várias atividades o segurado exercer a mesma profissão, será exigido de imediato o afastamento de todas. 
A concessão do auxílio-doença, portanto, leva em consideração à incapacidade uniprofissional e pode ser mantido indefinidamente, na hipótese de o segurado permanecer exercendo normalmente outra atividade concomitante. ${ }^{76}$

A incapacidade multiprofissional impossibilita a própria subsistência do segurado, porque abrange diversas atividades profissionais. Esse tipo de incapacidade é que pode propiciar a percepção da aposentadoria por invalidez, desde que seja insuscetível de recuperação ou reabilitação. ${ }^{77}$

O Manual de Reconhecimento Inicial de Direitos, aprovado pela Resolução $n^{\circ}$ 258/PRES/INSS, de 14 de dezembro de 2012, define a invalidez como:

a) invalidez: a incapacidade laborativa total, indefinida e multiprofissional (aquela em que o impedimento abrange diversas atividades profissionais), insuscetível de recuperação ou reabilitação profissional, que corresponde à incapacidade geral de ganho, em consequência de doença ou acidente;

Finalmente, a incapacidade omniprofissional é a que representa a impossibilidade do desempenho de toda e qualquer atividade laborativa, tal qual o segurado que esteja em coma ou que viva no chamado estado vegetativo.

\footnotetext{
${ }^{76}$ Decreto 3.048/99: Art.74. Quando o segurado que exercer mais de uma atividade se incapacitar definitivamente para uma delas, deverá o auxílio-doença ser mantido indefinidamente, não cabendo sua transformação em aposentadoria por invalidez, enquanto essa incapacidade não se estender às demais atividades.

Parágrafo único. Na situação prevista no caput, o segurado somente poderá transferir-se das demais atividades que exerce após o conhecimento da reavaliação médico-pericial.

${ }^{77}$ Lei 8.213/91: Art. 42. A aposentadoria por invalidez, uma vez cumprida, quando for o caso, a carência exigida, será devida ao segurado que, estando ou não em gozo de auxílio-doença, for considerado incapaz e insusceptível de reabilitação para o exercício de atividade que lhe garanta a subsistência, e ser-lhe-á paga enquanto permanecer nesta condição.
} 


\title{
CAPÍTULO 3 \\ O RECONHECIMENTO DA INCAPACIDADE LABORATIVA
}

\subsection{Caracterização no contrato de trabalho}

A dificuldade no tratamento teórico de definir e classificar a incapacidade laborativa por doença ganha contornos de maior complexidade quando se passa a analisá-la concretamente no contrato de trabalho.

Isso porque outros aspectos não técnicos passam a interferir a respeito, dos quais se destacam:

a) a comodidade do trabalhador em perceber renda sem trabalho

Esse ponto leva em consideração a natureza humana, especificamente da cultura brasileira, de sempre querer levar vantagem em uma situação ou, no relato de Carlos Lessa, conservar-se e inovar: ${ }^{78}$

\begin{abstract}
Em alguns casos a criatividade é espantosa. Em 1904, quando Oswaldo Cruz, para combater a peste bubônica, passou a comprar ratos, surgiram intermediários, que corriam as ruas comprando ratos. Apareceu inclusive um "criador de ratos". Esta prática levou à composição, em 1904, de uma polca chamada Rato! Rato!, de Casemiro da Rocha: "Rato! Rato! Rato!/ Por que motivo tu/ Roeste meu baú?/ (...) Meu tostão é garantido/ Não te solto nem a pau". É um povo pedagogicamente acostumado à precariedade, que combina a conservação (não abre mão de nada, pois não pode praticar esse luxo) com a inovação (pois continuamente prospecta brechas para sobreviver). É crescente sua sensibilidade e atenção às novas brechas, na medida em que se expande e diversifica a cidade.
\end{abstract}

Os aspectos psicológicos de vitimização, desorganização do planejamento familiar entre outras questões de cunho social (ausência de serviço de saúde e reabilitação profissional eficientes, empregadores desinteressados na recuperação ocupacional do empregado), influenciam de sobremaneira na

\footnotetext{
${ }_{78}$ LESSA, CARLOS. O Rio de todos os Brasis. 1. ed. Rio de Janeiro: Record, 2000, p.228.
} 
permanência do status quo, com a máxima: "se você tem que provar que está doente, você não pode melhorar"! ${ }^{79}$

Enfim, gostando ou não, esse é o retrato brasileiro há mais de século, a passar pela criação artística do Zé Carioca, de Walt Disney e chegar na ausência de registro do contrato de trabalho para impedir a suspensão do segurodesemprego ${ }^{80}$ ou, mais recentemente, do bolsa-família ${ }^{81}$

O que nos importa para o presente estudo é que a previdência social está atenta a esse comportamento, denominado "risco moral"82.

Os sistemas de seguro social enfrentam atualmente um problema socioeconômico de como lidar com o aumento crescente da demanda aos benefícios por incapacidade sem que haja o correspondente aumento dos recursos necessários para a sobrevivência deste importante mecanismo de Proteção Social. Muito tem sido feito nos últimos anos para enfrentar a gestão deste impasse em nosso sistema de seguro social. A criação de uma carreira de médicos próprios, o estabelecimento de novas regras para a identificação e o reconhecimento de direito a benefícios para doenças ocupacionais e a abertura de agências da Previdência Social para o atendimento específico a este tipo de demanda são exemplos de medidas que, em princípio, visam controlar o chamado "risco moral" que ameaça a saúde do sistema.

O "risco moral" (do inglês, "moral hazard") é um problema típico a qualquer sistema de seguro. Trata-se de uma condição de risco falimentar do sistema e caracteriza-se pela falta de responsabilidade financeira seja por parte do usuário seja por parte do prestador do serviço. O caso específico do seguro social, dependendo do grau em que as sociedades oferecem compensações para incapacidades, os indivíduos são mais ou menos voltados a se caracterizarem como incapazes. E, quando o desemprego é uma das características da

${ }^{79}$ INSS - Manual de Procedimentos de Benefícios por Incapacidade (MPBI) - Volume I, Diretrizes de Apoio à Decisão Médico-Pericial em Ortopedia e Traumatologia, op. cit., 2008, p. 9.

${ }^{80} \mathrm{O}$ artigo $7^{\circ}$, II, e artigo 239 da Constituição Federal prevêem a criação de seguro-desemprego para o desemprego involuntário. Esse direito social é regulamentado pela Lei 7.998/90 e garante, em geral, de três a cinco meses de renda para o trabalhador nessa situação. O benefício é suspenso imediatamente quando o trabalhador se recoloca formalmente no mercado de trabalho.

${ }^{81}$ LEI $n^{\circ}$. 10.836, de 9 de janeiro de 2004. Cria o Programa Bolsa Família. Disponível em:<http://www.planalto.gov.br/ccivil_03/_ato2004-2006/2004/lei//10.836.htm>; acesso em $05 \mathrm{dez}$ 2014.

Trata-se de programa de renda regulamentado pela Lei 10.836/2004 destinado às famílias com renda mensal per capita de até $\mathrm{R} \$ 120,00$. A ausência de registro formal de emprego impede a fiscalização do recebimento desse benefício. Embora não comuns, há defesas de empregadores alegando que a ausência de registro do contrato de trabalho tinha como finalidade a manutenção do bolsa-família para o trabalhador, porque de seu interesse.

${ }^{82}$ INSS - Manual de Procedimentos de Benefícios por Incapacidade (MPBI) - Volume I: Diretrizes de Apoio à Decisão Médico-Pericial em Ortopedia e Traumatologia. op. cit., 2008, p. 9. 
sociedade, maior é a busca por este tipo de seguro, havendo conflitos nas tentativas de fazer com que os indivíduos retornem ao trabalho.

Em que pese a identificação necessária da falta de responsabilidade do usuário para o equilíbrio financeiro do sistema previdenciário (de natureza solidária), percebe-se que as questões orçamentárias e o déficit previdenciário passaram a assumir papel crucial para a concessão de benefícios decorrentes da incapacidade de trabalho, o que veremos a seguir.

\section{b) orçamento público da Previdência Social}

A previdência social é custeada por toda a sociedade, de forma direta e indireta, na forma do artigo 195 da Constituição Federal ${ }^{83}$.

De notório conhecimento a preocupação com o déficit da previdência social. Segundo propagado pelo governo federal e pela imprensa em geral, a previdência social arrecada menos do que gasta. A informação é repudiada com veemência por trabalhos especializados, que destacam o desvio de recursos

\footnotetext{
${ }^{83}$ Art. 195. A seguridade social será financiada por toda a sociedade, de forma direta e indireta, nos termos da lei, mediante recursos provenientes dos orçamentos da União, dos Estados, do Distrito Federal e dos Municípios, e das seguintes contribuições sociais:

I - do empregador, da empresa e da entidade a ela equiparada na forma da lei, incidentes sobre: (Redação dada pela Emenda Constitucional n 20 , de 1998)

a) a folha de salários e demais rendimentos do trabalho pagos ou creditados, a qualquer título, à pessoa física que lhe preste serviço, mesmo sem vínculo empregatício; (Incluído pela Emenda Constitucional $n^{\circ} 20$, de 1998)

b) a receita ou o faturamento; (Incluído pela Emenda Constitucional nº 20, de 1998)

c) o lucro; (Incluído pela Emenda Constitucional n 20, de 1998)

II - do trabalhador e dos demais segurados da previdência social, não incidindo contribuição sobre aposentadoria e pensão concedidas pelo regime geral de previdência social de que trata o art. 201; (Redação dada pela Emenda Constitucional n²0, de 1998)

III - sobre a receita de concursos de prognósticos.

IV - do importador de bens ou serviços do exterior, ou de quem a lei a ele equiparar. (Incluído pela Emenda Constitucional n 42 , de 19.12.2003)
} 
originados no artigo 195 da CF para outras finalidades ${ }^{84}$ e ocasionar a existência de déficit por manobra contábil.

O contigenciamento de despesas da previdência social impacta diretamente na estrutura administrativa responsável pela concessão do benefício por incapacidade e, por consequência, os efeitos no contrato de trabalho.

A alta programada instituída na concessão do benefício desde 2005 é prova concreta desse direcionamento. Os atuais manuais técnicos do INSS também são balizados nessa premissa ${ }^{85}$ :

A alternativa a este impasse surge com uma ousada proposta de mudança de paradigma: o retorno precoce ao trabalho. $O$ retorno precoce ao trabalho baseia-se na importância do trabalho como parte fundamental na vida da maioria das pessoas, pois o trabalho confere não somente segurança e status financeiro, mas também confere uma ocupação, uma atividade, senso de identidade e objetivo na vida e interação social. As melhores evidências médicas sugerem que o retorno mais precocemente possível às atividades normais incluindo o trabalho - melhora o bem-estar e potencializa a recuperação na maioria das pessoas. Complexas intervenções clínicas ou programas de tratamentos de custos elevados nem sempre são necessários. Ao contrário, recomenda-se que os indivíduos devam ser "empoderados" para gerenciar seus sintomas e se engajem em suas atividades habituais. É interesse de todos que os recursos da previdência social sejam alocados com eficiência, o que requer também uma mudança na mentalidade empresarial no sentido de uma ampliação de programas preventivos e de reabilitação de seus funcionários afastados. O retorno precoce ao trabalho preconiza a reabilitação antes da compensação e a prevenção antes da reabilitação. Mostra-se altamente relevante para o bem estar mental, social e físico e ao ser identificado um desfecho mensurável favorece a pesquisa científica e o desenvolvimento de estudos comparativos entre diferentes intervenções. $\mathrm{O}$ abismo atual que afasta a medicina assistencial das atividades médicas do seguro social, a falta de legislação pertinente, o impacto de fatores socioeconômicos e a falta de protocolos médicos específicos impedem 0 atual desenvolvimento desta proposta. Assim, encontramos nesta alternativa uma orientação, um longo caminho a

${ }^{84}$ GENTIL, Denise Lobato. A Política Fiscal e a Falsa Crise da Seguridade Social Brasileira Análise financeira do período 1990-2005. Tese [Doutorado] apresentada ao Programa de PósGraduação-Doutorado do Instituto de Economia da Universidade Federal do Rio de Janeiro, 2006. Disponível em:

$<$ http://www.ie.ufrj.br/images/pesquisa/publicacoes/teses/2006/a_politica_fiscal_e_a falsa_crise_d

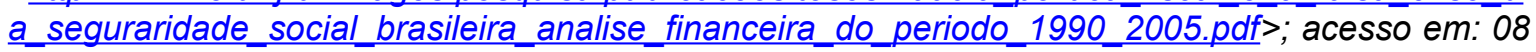
dez 2014.

${ }^{85}$ Manual de Procedimentos de Benefícios por Incapacidade (MPBI) - Volume I: Diretrizes de Apoio à Decisão Médico-Pericial em Ortopedia e Traumatologia. 
ser seguido. Ousamos dar o primeiro passo ao elaborar estas diretrizes.

Em suma, pode-se asseverar que o trabalhador brasileiro convive com o retorno precoce ao trabalho em data previamente estabelecida. Os aspectos subjetivos da incapacidade para o trabalho (análise da doença do indivíduo no contexto de seu ambiente de trabalho) passaram a ser atropelados por procedimentos e ideias massificadas, que afetam seriamente o contrato de trabalho.

Em 31/12/2014, adveio a Medida Provisória $n^{\circ}$ 664, restringindo diversos direitos previdenciários, alguns com impactos diretos no contrato de trabalho, em explícita contenção das despesas públicas. Até o fechamento desse trabalho, há quatro ações diretas de inconstitucionalidade no Supremo Tribunal Federal a respeito ${ }^{86}$.

\subsection{Os primeiros 15 dias (30 dias após MP 664/2014)}

O pagamento do salário ao empregado incapacitado para o trabalho nos primeiros 15 (quinze) dias se originou da uniformização do então chamado auxílio-enfermidade, pelo advento do Decreto-Lei 6.905/44, e consagrou-se como paradigma das legislações posteriores. A Medida Provisória 664/2014 aumentou esse período para 30 (trinta) dias, ressurgindo o prazo primórdio desse instituto no Brasil.

Esse é o denominado período de espera e o pagamento pelo empregador é denominado de salário-enfermidade.

\footnotetext{
${ }^{86}$ A referida Medida Provisória é objeto de ações diretas de inconstitucionalidade no Supremo Tribunal Federal (ADI n ${ }^{\circ}$ 5.230, 5.232, 5.234 e 5.238), de Relatoria do Ministro Luiz Fux, sob os principais fundamentos: a) falta de relevância e urgência para edição de medida provisória; b) regulamentação de comando constitucional alterado por emenda aprovada entre 1995 e 2001; c) violação aos princípios da dignidade da pessoa humana, da proporcionalidade e da isonomia, resultando em inadmissível retrocesso social; d) reciprocidade no princípio da prévia fonte de custeio, alegando que se a Previdência não pode pagar mais que o devido, também não pode pagar menos com a mesma arrecadação. Fonte: Secretaria de Comunicação Social do STF: www.stf.jus.br.
} 
O fundamento de essa responsabilidade ter sido atribuída ao empregador, segundo Santoro Passarelli ${ }^{87}$, é "a dedicação do empregado à empresa e a específica solidariedade que essa dedicação impõe ao empregador com relação ao trabalhador como partícipe da comunidade do trabalho".

O empregado doméstico não recebe o salário-enfermidade porque o artigo 60, caput, da Lei 8.213/91, apenas se refere ao segurado empregado e o empregado doméstico é tratado pela lei como outra espécie de segurado (artigos 11, I e II, da Lei 8.213/91). Por essa razão, o artigo 72, I e II, do Decreto 3.048/99 e artigo 303, I e II, da IN INSS/PRES 77, de 21/01/2015, estabelecem que a data do início do benefício de auxílio-doença é a data de início da incapacidade, quando requerido nos primeiros 30 dias da incapacidade ou a partir do requerimento, quando realizado após o $30^{\circ}$ dia.

A nova redação do artigo 60 da Lei 8.213/91 pela MP 664/2014 deixou mais clara a questão:

\begin{abstract}
Art. 60. O auxílio-doença será devido ao segurado que ficar incapacitado para seu trabalho ou sua atividade habitual, desde que cumprido, quando for o caso, o período de carência exigido nesta Lei: I - ao segurado empregado, a partir do trigésimo primeiro dia do afastamento da atividade ou a partir da data de entrada do requerimento, se entre $\mathrm{o}$ afastamento e a data de entrada do requerimento decorrerem mais de quarenta e cinco dias; e

II - aos demais segurados, a partir do início da incapacidade ou da data de entrada do requerimento, se entre essas datas decorrerem mais de trinta dias.
\end{abstract}

\title{
3.2.1. A comprovação da incapacidade laborativa ${ }^{88}$
}

Atualmente, o pagamento dos primeiros 15 dias de afastamento por doença decorre de norma expressa prevista no artigo $60, \S 3^{\circ}$, da Lei $8.213 / 91$ :

\footnotetext{
${ }^{87}$ PASSARELLI, Santoro. Noções de Direito do Trabalho. 1. ed. São Paulo: Editora Revista dos Tribunais, 1973, p.162.

${ }^{88}$ Registre-se a existência do Acordo Multilateral de Seguridade Social do Mercado Comum do Sul, aprovado pelo Decreto $n^{\circ}$ 5.722, de 13 de março de 2006, em que (artigo 9, item 2, do Regulamento Administrativo) compete ao Organismo de Ligação do Estado avaliar a incapacidade temporária ou permanente, emitindo certificado correspondente para análise do Organismo de Ligação do outro Estado a fim de pagamento dos benefícios de incapacidade.
} 
$\S 3^{\circ}$ Durante os primeiros quinze dias consecutivos ao do afastamento da atividade por motivo de doença, incumbirá à empresa pagar ao segurado empregado o seu salário integral. (Redação dada pela Lei $n^{\circ}$ 9.876, de 26.11.99).

A nova redação do dispositivo conferido pela MP 664/2014 passou a

ser:

$\S 3^{\circ}$ Durante os primeiros trinta dias consecutivos ao do afastamento da atividade por motivo de doença ou de acidente de trabalho ou de qualquer natureza, caberá à empresa pagar ao segurado empregado o seu salário integral.

A efetividade da referida norma no contrato de trabalho pressupõe alguns problemas a serem enfrentados no cotidiano das relações contratuais.

O primeiro dele, antigo, é o abono de faltas nesse período. A Lei $5.890 / 73$ inseriu no ordenamento jurídico nacional dispositivo praticamente repetido na legislação vigente e consistente em verbete sumular do Tribunal Superior do Trabalho.

O artigo $60, \S^{\circ}$, da Lei 8.213/91 dispõe que:

$\S 4^{\circ} \mathrm{A}$ empresa que dispuser de serviço médico, próprio ou em convênio, terá a seu cargo o exame médico e o abono das faltas correspondentes ao período referido no $\S 3^{\circ}$, somente devendo encaminhar o segurado à perícia médica da Previdência Social quando a incapacidade ultrapassar 15 (quinze) dias. ${ }^{89}$

E a Súmula 282 do TST:

282 - Abono de faltas. Serviço médico da empresa (Res. 15/1988, DJ 01.03.1988)

Ao serviço médico da empresa ou ao mantido por esta última mediante convênio compete abonar os primeiros 15 (quinze) dias de ausência ao trabalho.

A obrigatoriedade de serviço médico próprio é determinada segundo o número de empregados e grau de risco do empregador, na forma da Norma

\footnotetext{
${ }^{89}$ A nova redação do dispositivo conferido pela MP 664/2014: § 40 A empresa que dispuser de serviço médico, próprio ou em convênio, terá a seu cargo o exame médico e o abono das faltas correspondentes ao período referido no $\S 3$ e e somente deverá encaminhar o segurado à perícia médica da Previdência Social quando a incapacidade ultrapassar trinta dias.
} 
Regulamentadora $n^{\circ} 4$, aprovada pela Portaria GM $n^{\circ} 3.214$, de 08 de junho de 1978, por autorização do artigo 155 da CLT. Segundo essa norma, as empresas com grau de risco 3 ou 4, que contenham a partir de 501 empregados, necessitam de médico do trabalho em seu SESMT - Serviços Especializados em Engenharia de Segurança e em Medicina do Trabalho.

O serviço médico em convênio pode ser prestado por empresas especializadas em medicina do trabalho contratadas pelo empregador, por formação de SESMT comum (na forma da NR $n^{\circ} 4$ ) ou, até mesmo, por operadora de plano de assistência à saúde (Lei nº 9.656/98).

Compete a esse serviço médico, próprio ou em convênio, realizar o exame médico e o abono de faltas correspondentes a esse período.

O problema passa a ganhar complexidade quando a empresa não tem o serviço médico próprio ou conveniado. No cotidiano, pode-se asseverar que isso ocorre com a maioria dos empregos formais no Brasil, pois originados em micro ou pequenas empresas. ${ }^{90}$

Não existe norma trabalhista que determine como se demonstra a incapacidade laborativa no contrato de trabalho para as empresas que não detém serviço médico.

A esse problema, a jurisprudência do Tribunal Superior do Trabalho há muito tempo se socorria à analogia do artigo $6^{\circ}$ da Lei $605 / 49 .^{91}$

...de concluir que inexiste, na legislação em vigor, disciplinação alusiva à comprovação da doença do empregado para percepção do salário-enfermidade. $\mathrm{E}$, nessa hipótese, teremos de recorrer, por analogia, ao estatuído no art. $6^{\circ}$, da Lei $n^{\circ} 605$, de 1949 , cujo $\S 2^{\circ}$, na redação dada pela Lei 2.761, é explícito ao estabelecer a ordem preferencial dos atestados médicos.

${ }^{90}$ SEBRAE - Serviço Brasileiro de Apoio às Micro e Pequenas Empresas. Participação das Micro e Pequenas Empresas na Economia Brasileira. Brasília, julho/2014, p. 7.

${ }^{91}$ Acórdão TST 1.768/66 - 1 a Turma - Rel. Min. Arnaldo Sussekind. 
O mencionado dispositivo legal estabelece que:

Art. $6^{\circ}$ Não será devida a remuneração quando, sem motivo justificado, o empregado não tiver trabalhado durante toda a semana anterior, cumprindo integralmente o seu horário de trabalho.

$\S 2^{\circ} \mathrm{A}$ doença será comprovada mediante atestado de médico da instituição da previdência social a que estiver filiado o empregado, e, na falta dêste e sucessivamente, de médico do Serviço Social do Comércio ou da Indústria; de médico da emprêsa ou por ela designado; de médico a serviço de representação federal, estadual ou municipal incumbido de assuntos de higiene ou de saúde pública; ou não existindo êstes, na localidade em que trabalhar, de médico de sua escôlha. (Redação dada pela Lei $n^{\circ} 2.761$, de 26.4.56)

A partir disso, o Tribunal Superior do Trabalho passou a fixar entendimento de que a comprovação da incapacidade para o trabalho deveria observar a ordem preferencial dos atestados médicos. Essa jurisprudência acabou por se transformar em verbete da súmula 15:

15 - Atestado médico (RA 28/1969, DO-GB 21.08.1969)

A justificação da ausência do empregado motivada por doença, para a percepção do salário-enfermidade e da remuneração do repouso semanal, deve observar a ordem preferencial dos atestados médicos estabelecida em lei.

Atualmente, permanece pacífica a jurisprudência no Tribunal Superior do Trabalho sobre a necessidade de se seguir a ordem preferencial do artigo $6^{\circ}$ da Lei 605/49:

RECURSO DE REVISTA. PROCEDIMENTO SUMARÍSSIMO. ATESTADO MÉDICO. ABONO DE FALTAS. SERVIÇO MÉDICO DA EMPRESA. I. A Corte Regional negou provimento ao recurso ordinário interposto pela Reclamada e manteve sua condenação ao pagamento dos valores descontados do Autor a título de falta, por reconhecer a validade do atestado médico apresentado pelo Reclamante para fins de abono de falta, sob o fundamento de não haver obrigatoriedade de o empregado consultar o médico da empresa na hipótese. II. É pacífico, no âmbito desta Corte Superior, o entendimento de que, havendo serviço médico nas dependências da empresa, o empregado que pretende abonar os primeiros quinze dias de falta deve submeter-se primeiramente ao atendimento do médico da empresa. Uma vez preterida esta ordem legal de preferência pelo Reclamante, que apresenta atestado de profissional estranho ao serviço ou convênio médico da empresa, fica caracterizada contrariedade às Súmulas $n^{\circ} 15$ e 282 do TST. III. Nesse contexto, a decisão proferida pelo Tribunal Regional no sentido de reconhecer a validade de atestado passado por médico estranho aos quadros da 
empresa para fins de abono dos primeiros quinze dias de falta do Reclamante, embora reconhecida a existência de serviço médico no âmbito da Reclamada, contraria o entendimento consolidado na Súmula $n^{\circ} 282$ do C. TST. IV. Recurso de revista de que se conhece, por contrariedade à Súmula $n^{\circ} 282 / T S T$, e a que se dá provimento, para afastar a validade do atestado apresentado pelo Autor para fins de abono dos primeiros quinze dias de falta e julgar improcedente a presente reclamação trabalhista

(Processo: RR - 103200-57.2008.5.12.0010 Data de Julgamento: 07/03/2012, Relator Ministro: Fernando Eizo Ono, $4^{\mathrm{a}}$ Turma, Data de Publicação: DEJT 23/03/2012)

Em que pese a construção jurídica realizada por analogia à Lei 605/49, não há mais como ser sustentada. Analisemos cada uma das hipóteses estabelecidas nesse antigo diploma normativo:

a) da Previdência Social a que estiver vinculado: a previdência social foi unificada pela Lei 3.807/60 e, desde então, não há que se falar em vinculação obrigatória a outro sistema de previdência (salvaguardado o regime próprio de ente federativo, que não é objeto do presente estudo). A previdência social não mais é responsável pelo serviço médico de saúde pública, matéria atualmente afeta ao Sistema Único de Saúde (artigo 196 da CF e Lei 8.080/90). Nesse ponto, a sucessividade histórica das atribuições de saúde para o SUS levou à conclusão majoritária, de que compete primariamente aos médicos desse sistema atestar a incapacidade de trabalho nos 15 primeiros dias, em que pese entendimentos em contrário:

Como já não existe mais a instituição de previdência social separada por categoria de trabalhadores, há dúvidas sobre a recepção desse dispositivo legal e, em caso afirmativo, sobre a ordem preferencial de apresentação de atestados médicos, por não se poder afirmar que o Sistema Único de Saúde assumiu diretamente o lugar das caixas de previdência setorizadas.... De qualquer forma, a divergência se concentra tão somente no abono da falta para o fim dos descansos semanais remunerados, porque do artigo 473 da CLT, repita-se, o assunto é omitido. ${ }^{92}$

b) médico do SESI ou SESC: além de inexistir serviço médico dessas duas entidades do terceiro setor em todos os lugares do país, o que impediria a comprovação da incapacidade do trabalhador, as atuações dessas instituições

${ }_{92}$ SILVA, Homero Batista Mateus da. Curso de direito do trabalho aplicado: contrato de trabalho. Rio de Janeiro: Campus Elsevier, 2009. vol. 6, p. 220. 
são limitadas de acordo com as normas que as regulamentam, não atendendo, por exemplo, empregados públicos (salvo com algum convênio específico).

c) médico da empresa ou em convênio com a mesma: essa ordem sucessiva não mais existe por expressa previsão do artigo $60, \S^{\circ}$, da Lei 8.213/91. Nessa hipótese, a legislação trabalhista reconhece como forma expressa de reconhecimento da incapacidade laborativa, não havendo que se socorrer de qualquer analogia. Inexiste lacuna no ordenamento jurídico a esse respeito, devendo a incapacidade laborativa ser atestada por esse serviço médico, conforme analisado anteriormente.

d) médico a serviço de repartição federal, estadual ou municipal: a integração das ações de saúde federais, estaduais e municipais no SUS ${ }^{93}$ englobou esses serviços médicos e, no entendimento atual, inusitadamente, essa hipótese passou de quarta opção preferencial para a primeira, na inexistência de serviço médico próprio ou conveniado da empresa.

e) médico de convênio sindical: os sindicatos normalmente contém serviço médico para membros associados de sua categoria profissional. Diante da liberdade de associação do trabalhador ao sindicato, a limitação de atendimento médico apenas aos associados do sindicato propiciaria questão inusitada: o empregador poderia negar validade a atestado médico trazido pelo empregado, sob o argumento que o sindicato tem esse serviço médico e não foi respeitada a ordem preferencial dos atestados médicos.

f) médico da preferência do empregado: como última opção na ordem preferencial de comprovação da incapacidade laborativa, a lei possibilita que o empregado apresente atestado firmado por médico de sua preferência.

\footnotetext{
${ }^{93}$ Lei 8.080/90 - Art. $4^{\circ} \mathrm{O}$ conjunto de ações e serviços de saúde, prestados por órgãos e instituições públicas federais, estaduais e municipais, da Administração direta e indireta e das fundações mantidas pelo Poder Público, constitui o Sistema Único de Saúde (SUS).

$\S 1^{\circ}$ Estão incluídas no disposto neste artigo as instituições públicas federais, estaduais e municipais de controle de qualidade, pesquisa e produção de insumos, medicamentos, inclusive de sangue e hemoderivados, e de equipamentos para saúde.
} 
A fixação normativa de ordem preferencial para comprovação da incapacidade laborativa não afronta as normas constitucionais. Isso ocorre porque não se trata de estabelecer a submissão do empregado a procedimento médico ou tratamento de saúde. Trata-se de estabelecer competência para verificar as condições de saúde do empregado a fim de que produza efeitos em um contrato de trabalho.

O que ganha relevo na atualidade é a completa defasagem da ordem preferencial da Lei 605/49 com a nova sistemática das ações de saúde no país, a inversão da ordem preferencial originariamente nela estabelecida, bem como pela disposição expressa do artigo $60, \S 4^{\circ}$, da Lei 8.213/91, havendo doutrina que defenda a revogação daquele dispositivo:

Esclareça-se, por fim, que a ordem preferencial a ser observada é aquela constante do $\S 4^{\circ}$, do art. 60 da Lei n. 8.213/91 e não mais aquela disposta no $\S 2^{\circ}$ do art. $6^{\circ}$ da lei n. 605/49, revogada nos termos do $\S 1^{\circ}$, art. $2^{\circ}$, da Lei de Introdução ao Código Civil. ${ }^{94}$

É impossível conceber que a incapacidade laborativa não produza efeitos no contrato de trabalho simplesmente porque não observada a formalidade da ordem preferencial dos atestados médicos.

O direito social à previdência (artigo $6^{\circ}$ da Constituição Federal), a cobertura de doença (artigo 201, I, da Constituição Federal) e o artigo 14 da Convenção no 102 da OIT $^{95}$ (aprovada pelo Decreto Legislativo 269, de 18 de setembro de 2008) constituem um sistema jurídico de proteção ao trabalhador portador de incapacidade laborativa que não pode ser repelido por simples formalidade de legislação ordinária ancilosa (e pior: aplicada por analogia).

Os direitos sociais constitucionais são normas de direitos fundamentais, com força normativa e de aplicabilidade imediata. A restrição

${ }^{94}$ VIANNA, Cláudia Salles Vilela. A relação de emprego e os impactos decorrentes dos benefícios previdenciários. 2. ed. São Paulo: LTR, 2010, p. 83.

${ }^{95}$ Art. $14-O$ evento coberto deve abranger a incapacidade de trabalho decorrente de um estado mórbido que acarrete a suspensão de ganhos, conforme for definida pela legislação nacional. 
injustificável desses direitos pela ordem preferencial da Lei 605/49 e Súmula 15 do TST não mais encontram guarida no ordenamento jurídico do país.

A corroborar o ancilosamento dessa norma e do entendimento jurisprudencial, pode-se destacar a impossibilidade de se estabelecer ordem preferencial quanto aos atestados fornecidos pelo cirurgião-dentista.

Com efeito, na forma do artigo $6^{\circ}$ da Lei $5.081 / 66$ :

Art. $6^{\circ}$ Compete ao cirurgião-dentista:

III - atestar, no setor de sua atividade profissional, estados mórbidos e outros, inclusive, para justificação de faltas ao emprego.(Redação dada pela Lei $n^{\circ} 6.215$, de 1975)

Essa regra confere ao cirurgião-dentista a competência de atestar estados mórbidos no âmbito de sua atividade profissional para justificar faltas ao emprego. Não existe qualquer distinção na regra, não cabendo ao intérprete em realizá-la.

Da mesma forma, a novel lei do ato médico (Lei 12.842/2013) também atribui competência a qualquer médico em atestar as condições de saúde, sem restrição ou estabelecimento de ordem preferencial na hipótese. Confira:

Art. $4^{\circ}$ São atividades privativas do médico:

XIII - atestação médica de condições de saúde, doenças e possíveis sequelas;

A exigência da ordem preferencial dos atestados médicos na forma da Lei 605/49 representa, em última análise, negar vigência à atividade privativa praticada por qualquer médico, criando distinção não prevista na norma.

Por se tratar de regra geral, não revogou a disposição especial do artigo $60, \S 4^{\circ}$, da Lei 8.213/91. 
Destarte, o reconhecimento da incapacidade laborativa no contrato de trabalho estará sujeita à regra especial do artigo $60, \S^{\circ}$, da Lei 8.213/91 (serviço médico da empresa) ou, na ausência, à apresentação de documento firmado por qualquer médico (artigo $4^{\circ}$, XIII, da Lei 12.842/2013) ou dentista (artigo $6^{\circ}$, da Lei 5.081/66) que ateste essa condição.

Necessário ainda salientar que nem mesmo essa conclusão é absoluta. Basta observar a realidade de ser o Brasil do tamanho de um continente e que existem regiões, até hoje, não atendidas por médicos. ${ }^{96}$ Nessas hipóteses, a justiça do trabalho chegou a admitir a prova da incapacidade para o trabalho por meio de testemunha ou qualquer outro meio idôneo. ${ }^{97} \mathrm{Com}$ razão, eis que o problema de saúde pública no país não pode ser arcada pelo trabalhador para a prova da justificativa de sua ausência ao trabalho.

A problemática real da compra de atestados médicos ${ }^{98}$ pode ser superada pela utilização de serviço médico próprio ou conveniado pela empresa, ou seja, pode o empregador invocar a prerrogativa legal (artigo 60 , $\S 4^{\circ}$, da Lei 8.213/91) para a constatação da realidade do atestado apresentado, encaminhando o empregado a serviço médico para, posteriormente, abonar as ausências ${ }^{99}$. Não pode, simplesmente, negar a comprovação da incapacidade laborativa diante de atestado firmado por profissional legalmente habilitado para tanto.

\footnotetext{
${ }^{96}$ Vide Lei $12.871 / 13$ que criou o Programa Mais Médicos, iniciativa originada pela desigualdade regional na área da saúde.

${ }^{97}$ Acórdão TRT 6 a Região, processo no 986/70; acórdão TRT $8^{\text {a }}$ Região, processo ${ }^{\circ} 382 / 74$. Apud LINS, Edilberto Quintela Vieira. Incapacidade executiva de trabalho e contrato de emprego: direito do trabalho e previdência social. Imprenta: Rio de Janeiro: Forense, 1984, p. 17.

${ }^{98}$ No Município de São Paulo é notoriamente conhecida a venda de atestados médicos nas redondezas da Praça da Sé. A respeito, vide notícia da Secretaria de Segurança Pública do Estado de São Paulo, de 05/07/2013, no link: http://www.ssp.sp.gov.br/noticia/lenoticia.aspx? id=31706. Acesso em 10/12/2014. Essa situação fática também é justificativa para o Projeto de Lei 7360/2014 da Câmara dos Deputados, que propõe a notificação do empregador e do SUS pelo médico emitente do atestado. Solução, a meu ver, inocente porque não evitará a fraude em três vias. SSP - Secretaria de Segurança Pública do Estado de São Paulo. Falsários são presos durante venda de atestado médico. Matéria divulgada em 05 de julho de 2013. Disponível em: <http://www.ssp.sp.gov.br/noticia/lenoticia.aspx?id=31706>; acesso em 05 dez 2014.

${ }^{99}$ TRT $10^{\mathrm{a}} \mathrm{n}^{\circ} 00814201310110007,3^{\mathrm{a}}$ Turma, DEJT 19/12/2013.
} 


\subsubsection{O prazo para entrega de atestados ou submissão ao serviço médico}

Não existe norma trabalhista que estabeleça o prazo para entrega de atestados de incapacidade laborativa ou para a submissão do empregado ao serviço médico da empresa ${ }^{100}$.

Isso significa que o prazo pode ser estabelecido em norma coletiva (artigo 611 da CLT), cláusula individual do contrato de trabalho (artigo 444 da CLT) ou por regulamento empresarial (artigo $2^{\circ}$ da CLT), inserido nos poderes de direção do empregador.

Essa possível normatização deve estar inserida em dois princípios fundamentais à espécie: da razoabilidade e da boa-fé objetiva.

A ação humana não é regida por esquemas formais abstratos. A solução dos problemas práticos da existência humana pressupõe a lógica do razoável. Como os problemas jurídicos são dos mais relevantes entre os problemas da existência humana, há que se afastar a lógica formal quando se enfrenta problema desta natureza. Trata-se de aplicar a lógica do razoável, compatível com a realidade social na qual atua. O desarrazoado é inaceitável. A lógica do razoável leva em conta a situação pessoal do sujeito atingido pela aplicação da norma. A razoabilidade é aferida em função do conteúdo, não da forma. Uma solução jurídica é razoável quando material ou substancialmente aceitável, nos limites do racional, referenciada ao conceito de aceitabilidade racional, de que fala Aulis Aarnio. ${ }^{101}$

Segundo o princípio da razoabilidade, o dever jurídico (derivado da norma coletiva, cláusula contratual ou regulamento de empresa) de entrega do atestado médico deve ter seu prazo fixado de tal forma que seja possível seu cumprimento pelo trabalhador ou por seu familiar, mas que também não produza maiores prejuízos ao empregador.

\footnotetext{
100 O Projeto de Lei 4370/2008 da Câmara dos Deputados fixava o prazo de entrega no dia do retorno para afastamentos até 5 dias ou o prazo de 5 dias para afastamentos que superassem esse período. Esse projeto foi arquivado, em 1/02/2011, porque não concluída sua tramitação até o fim daquela legislatura (artigo 105 do Regimento Interno da Câmara dos Deputados).

${ }^{101}$ ROMITA, Arion Sayão. Direitos fundamentais nas relações de trabalhado. 3. ed. São Paulo: Ltr, 2009. p. 204.
} 
Não se pode olvidar que a comunicação da ausência do empregado por motivo de doença, salvo impossibilidade, deve ser realizada imediatamente. Esse comportamento é legitimamente esperado por seu empregador e exigido pelo princípio da boa-fé objetiva que rege as relações contratuais.

\begin{abstract}
A boa-fé objetiva é a que diz respeito ao aspecto ético do comportamento humano, isto é, corresponde a um modelo ideal de comportamento que a pessoa humana deve ter em relação a outras pessoas, devendo agir, pois, de forma ética, honesta, leal e proba, à luz dos valores sociais e morais reconhecidos pela sociedade e pelo ordenamento jurídico. ${ }^{102}$
\end{abstract}

Dessa forma, sabendo o empregado que não poderá cumprir sua obrigação de prestar serviço em determinado período por motivo de doença, deve comunicar seu empregador tão logo que possível, a fim de que sua ausência seja suprida segundo as necessidades do empreendimento. Assim, viola a boa-fé objetiva o empregado que simplesmente desaparece do emprego e comparece posteriormente com um atestado médico na mão.

DOENÇA E CONSEQÜENTE SUSPENSÃO DO CONTRATO DE TRABALHO. NULIDADE DA DISPENSA. A reclamante não foi diligente no sentido de avisar seu empregador acerca da necessidade de se afastar do trabalho por problemas de saúde, situação em que, se fosse o caso, teria seu contrato de trabalho interrompido por quinze dias e, se persistisse o problema, suspenso pelo tempo necessário. Não o fazendo e tendo se ausentado por dez dias, sem qualquer justificativa, preferiu correr o risco de ser dispensada pela reclamada, que assim agiu dentro dos limites do jus variandi. PROCESSO TRT/SP $N^{\circ}$ : 01535200605502009. Rel. ODETTE SILVEIRA MORAES. Julgamento: 22/04/2009

É de fundamental importância a normatização dessa questão a fim de que haja transparência entre os envolvidos na relação contratual trabalhista.

A boa-fé é princípio de mão dupla, porque tanto significa que o sujeito deve agir dentro dos padrões de lealdade e de decência do homem médio, como também representa que se espera esse mesmo comportamento da parte contrária. Não se pode lidar permanentemente com a desconfiança ou a com a certeza da traição.

${ }^{102}$ LEITE, Carlos Henrique Bezerra. Curso de Direito do Trabalho. 1. ed. São Paulo: Saraiva, 2014. p. 85 . 
Ambiente como esse está minado e não tem chances de prosperidade. ${ }^{103}$

Fixado o prazo razoável por qualquer norma, com a devida transparência perante os empregados, passa a ter a natureza jurídica decadencial.

\begin{abstract}
A decadência (também chamada caducidade) conceitua-se como a perda da possibilidade de obter uma vantagem jurídica e garanti-la judicialmente, em face do não exercício oportuno da correspondente faculdade de obtenção... Embora não sejam inúmeros os prazos decadenciais criados pela legislação heterônoma estatal, a figura pode assumir grande recorrência na normatividade autônoma (convenções, acordos ou contratos coletivos de trabalho). Mais do que isso, têm sido relativamente comuns os prazos decadenciais propiciados ainda por regulamentos de empresa. Todos esses diplomas ou instrumentos podem criar prazos fatais para exercícios de faculdades de aquisição de vantagens novas no âmbito concreto da relação de emprego - prazos, assim, de natureza decadencial. ${ }^{104}$
\end{abstract}

Assim, a ausência de entrega de atestado médico no prazo fixado acarreta na perda do direito de abono das faltas nos respectivos dias. ${ }^{105}$

Entretanto, cabe-se perquirir os efeitos decorrentes da inexistência de prazo fixado por qualquer fonte de direito.

Nesse caso, será necessário se socorrer novamente dos princípios da razoabilidade e boa-fé objetiva, a fim de que, diante do caso concreto, os participantes do contrato de trabalho solucionem a questão.

Não obstante, diante da sistemática do ordenamento jurídico que prevê o pagamento pelo INSS do auxílio-doença a partir do $16^{\circ}$ dia de afastamento (artigo 60, caput, da Lei 8.213/91) e encaminhamento ao INSS pela empresa (artigo 60, $\S 4^{\circ}$, da Lei 8.213/91), é razoável entender que o atestado médico deve ser entregue ao empregador até o $15^{\circ}$ dia de afastamento.

\footnotetext{
${ }^{103}$ SILVA, Homero Batista Mateus da. Curso de direito do trabalho aplicado: parte geral. Rio de Janeiro: Campus Elsevier, 2013. vol. 1, p. 272.

${ }^{104}$ DELGADO, op. cit., 2006, p. 250 e 251.

${ }^{105}$ Nesse sentido: TRT-2 № 00020789520125020088, $13^{\text {a }}$ Turma, DOE de 10/07/2014. TRT-10 n ${ }^{\circ}$ $714201101810002,1^{\text {a }}$ Turma, DEJT de 23/02/2012.
} 
O próprio artigo 76-A do Decreto 3.048/99 faculta ao empregador requerer o auxílio-doença para seu empregado, hipótese em que terá acesso às decisões administrativas respectivas. A fim de que seja possível a garantia dessa faculdade ao empregador e o encaminhamento do empregado ao INSS, necessariamente, $\mathrm{o}$ atestado médico deve ser entregue ao empregador nesse prazo.

Com a nova redação do artigo $60, \S 4^{\circ}$, da Lei $8.213 / 91$ pela Medida Provisória n ${ }^{\circ}$ 664/2014 alterou-se a concessão do auxílio-doença para a partir do $31^{\circ}$ dia. No mesmo raciocínio, isso significa que o emprego pode apresentar o atestado médico dentro do período de 30 (trinta) dias.

O atraso superior a 30 (trinta) dias para entrega do atestado da incapacidade laborativa, salvo impedimento justificável para não o realizar, consiste em evidente violação ao princípio da boa-fé objetiva e da razoabilidade, constituindo ato ilícito do empregado e suas faltas não devem ser abonadas. ${ }^{106}$

\subsubsection{A prorrogação dos afastamentos inferiores a 15 dias (a 30 dias após MP 664/2014)}

Outro problema antigo era "a incidência repetida de períodos de enfermidade inferiores a 15 dias, não dando margem à entrada do empregado no gozo do benefício previdenciário, ou recidivas logo após o término do benefício, gerava para as empresas um ônus não previsto, acarretando-lhes sucessivos pagamentos da vantagem". Edilberto Quintela Vieira Lins alertava ainda que, à época, a jurisprudência era vacilante ora fixando a responsabilidade do empregador a todos os afastamentos, ora negando-a. ${ }^{107}$

\footnotetext{
${ }^{106}$ Artigo 187 do Código Civil: Também comete ato ilícito o titular de um direito que, ao exercê-lo, excede manifestamente os limites impostos pelo seu fim econômico ou social, pela boa-fé ou pelos bons constumes.

${ }^{107}$ LINS, op. cit., 1984, p. 13.
} 
A solução adveio, historicamente, com o Decreto 48.959-A, de 19 de setembro de 1960 , que também foi adotada pelo atual artigo 75 , parágrafos $3^{\circ}$ a $5^{\circ}$, do regulamento da previdência social (Decreto 3.048/99) que estabelece:

$\S 3^{\circ}$ Se concedido novo benefício decorrente da mesma doença dentro de sessenta dias contados da cessação do benefício anterior, a empresa fica desobrigada do pagamento relativo aos quinze primeiros dias de afastamento, prorrogando-se o benefício anterior e descontando-se os dias trabalhados, se for o caso.

$\S 4^{\circ}$ Se o segurado empregado, por motivo de doença, afastar-se do trabalho durante quinze dias, retornando à atividade no décimo sexto dia, e se dela voltar a se afastar dentro de sessenta dias desse retorno, em decorrência da mesma doença, fará jus ao auxílio doença a partir da data do novo afastamento. (Redação dada pelo Decreto $\mathrm{n}^{\circ}$ 5.545, de 2005)

$\S 5^{\circ} \mathrm{Na}$ hipótese do $\S 4^{\circ}$, se o retorno à atividade tiver ocorrido antes de quinze dias do afastamento, o segurado fará jus ao auxílio-doença a partir do dia seguinte ao que completar aquele período. (Incluído pelo Decreto $n^{\circ} 4.729$, de 2003)

A ideia geral das hipóteses normativas é a de que o empregador somente pagará 15 dias (ou 30 dias após a MP 664/2014) dias de salário por motivo de uma mesma doença no interregno de 60 (sessenta) dias.

Por não existir na Lei 8.213/91 essa distinção criada no dispositivo regulamentar, suscita-se a sua invalidade por inovar no ordenamento jurídico (artigo $5^{\circ}, \mathrm{II}$, da CF $)^{108}$.

Com efeito, o decreto é ato administrativo expedido pelo Presidente da República para, em regra, regulamentar a fiel execução da lei (artigo 84, IV, da Constituição Federal).

Não pode, portanto, criar novas relações jurídicas no ordenamento sem lei que as estabeleça, sob pena de violação ao princípio da legalidade (artigo $5^{\circ}$, II, da Constituição Federal).

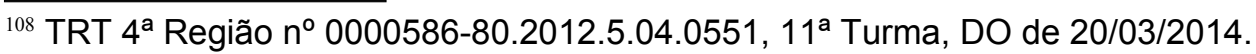


Todavia, a controvertida norma abstrata permanece em vigor e, usualmente, é aplicada no cotidiano da Justiça do Trabalho.

\begin{abstract}
ACIDENTE DE TRABALHO. AFASTAMENTO POR MAIS DE 15 DIAS, EM PERÍODOS DESCONTÍNUOS, NO INTERREGNO DE 60 DIAS - Da interpretação que se extrai do $\S \S 3^{\circ}$ e $4^{\circ}$ do art. 75 , do Decreto n.3.048/99, quando o empregado, por motivo da mesma doença, afasta-se do trabalho por mais de quinze dias, ainda que em períodos descontínuos, no interregno de 60 dias, faz jus ao auxíliodoença. (RO 639001120025050005 BA 0063900-11.2002.5.05.0005, TRT 5 ${ }^{\text {a }}$ Região, Rel. GRAÇA LARANJEIRA, $2^{\mathrm{a}}$ Turma, DJ 28/09/2004
\end{abstract}

Não nos parece que o artigo 75 do Decreto $3.048 / 99$ seja juridicamente inválido. Ele regulamentou situação de acordo com a interpretação teleológica ao artigo $60, \S 3^{\circ}$, da Lei 8.213/91.

Com efeito, a finalidade do dispositivo é de que o empregador pague os primeiros 15 dias (30 dias na nova sistemática da MP 664/2014) de afastamento por doença do empregado e para que a previdência social não se responsabilize por pequenos afastamentos em que o custo operacional se demonstraria desproporcional. O retorno ao trabalho e novo afastamento pela mesma doença não podem acarretar novo pagamento pelo empregador, porque não se tratam dos primeiros dias (pagos anteriormente), mas continuidade daquele afastamento primário (mesma origem).

Outrossim, seria juridicamente inadmissível, por traduzir enriquecimento ilícito, a obrigação de o empregador pagar 15 dias (ou 30 dias após MP 664/2014) de salário, por diversas vezes, em afastamentos sucessivos e, ao mesmo tempo, o trabalhador receber o auxílio-doença desses mesmos dias pela previdência social, porquanto conferido o benefício nessa situação (artigo 75 do Decreto 3048/99).

Esse entendimento dificulta também a manipulação de sucessivos atestados de até 15 dias (30 dias na nova sistemática da MP 664/2014) intercalados com um dia de trabalho. 
Finalmente, a contingência social criada pela incapacidade laborativa não pode ser desproporcionalmente ${ }^{109}$ arcada por um dos contratantes da relação de emprego, mas por toda a sociedade. Esse é o primado da seguridade social (art. 195 da Constituição Federal) e uma das finalidades de atendimento da previdência social (artigo 201, I, da Constituição Federal).

\subsection{Incapacidade a partir do $16^{\circ}$ dia $\left(31^{\circ}\right.$ dia após MP 664/2014)}

Após o período o abono de faltas previsto no artigo $60, \S 4^{\circ}$, da Lei 8.213/91, competirá ao INSS a concessão do auxílio-doença e, por conseguinte, consolidar a suspensão do contrato de trabalho.

O artigo $30, \S 3^{\circ}$, da Lei $11.907 / 09^{110}$ dispõe que compete privativamente ao Perito Médico Previdenciário as atividades médico-periciais inerentes ao Regime Geral da Previdência, ou seja, atestar a incapacidade laborativa.

Todavia, o artigo 117 , II, da lei $8.213 / 91$ previa a possibilidade de realização de convênio para realização do exame médico pericial por empresas, sindicatos ou entidades conveniadas para posterior homologação da Previdência Social. ${ }^{111}$

\footnotetext{
${ }^{109}$ Antes mesmo do advento do Decreto 48.959-A, de 19 de setembro de 1960, que inseriu essa sistemática do ordenamento jurídico brasileiro, o próprio pleno do Tribunal Superior do Trabalho não garantia novo pagamento do então denominado salário-enfermidade em relação à mesma doença após poucos dias de início da atividade. (Pleno, Processo n 2.626/53, Rel. Min. Caldeira Neto).

${ }^{110} \mathrm{O}$ artigo $2^{\circ}$ da Lei $10.876 / 2004$ já previa essa competência privativa.

${ }^{111}$ Art. 117. A empresa, o sindicato ou a entidade de aposentados devidamente legalizada poderá, mediante convênio com a Previdência Social, encarregar-se, relativamente a seu empregado ou associado e respectivos dependentes, de:

II - submeter o requerente a exame médico, inclusive complementar, encaminhando à Previdência Social o respectivo laudo, para efeito de homologação e posterior concessão de benefício que depender de avaliação de incapacidade;

A Resolução INSS/PR n 502, de 2 de dezembro de 1997, regulamentava as perícias realizadas por meio de convênios.

RESOLUÇÃO INSS/PR N N $^{5} 2$ DE 2 DE DEZEMBRO DE 1997. Dispõe sobre convênios para processamento, habilitação no aplicativo prisma e pagamento de benefícios previdenciários e acidentários, realização de exames médico-periciais, reabilitação profissional, e dá outras providências. Disponível em: <http://www010.dataprev.gov.br/sislex/paginas/72/INSSPR/1997/502.htm>; acesso em 05 dez 2014.
} 
Pelo MEMORANDO-CIRCULAR no 46 INSS/DIRBEN, de 19 de outubro de 2005, o INSS determinou o aditamento de todos os convênios para a supressão da perícia médica por convênio em razão da atividade privativa do médico-perito-previdenciário iniciada pela Lei 10.876/2004.

Com a edição da MP 664/2014, houve a inserção do $§ 5^{\circ}$, no artigo 60, da Lei 8.213/91, dispondo que:

§ 5o O INSS a seu critério e sob sua supervisão, poderá, na forma do regulamento, realizar perícias médicas:

I - por convênio ou acordo de cooperação técnica com empresas; e

II - por termo de cooperação técnica firmado com órgãos e entidades públicos, especialmente onde não houver serviço de perícia médica do INSS.

Destarte, a atividade de realização a perícia médica para a concessão do auxílio-doença não é mais privativa do Perito Médico Previdenciário.

Pode-se afirmar, portanto, que compete ao INSS ou entidades conveniadas o reconhecimento da incapacidade laborativa a partir do $16^{\circ}\left(31^{\circ}\right.$ segundo a MP 664/2014) dia de afastamento.

Outra questão relevante sobre a realização da perícia médica previdenciária é a necessidade ou não de ser realizada por especialista na doença do segurado.

A matéria foi pacificada pela Turma Nacional de Uniformização dos Juizados Especiais Federais da seguinte forma:

Perícia médica por especialista. A perícia não precisa ser realizada por médico especialista se se trata de doença ou quadro médico simples (PEDILEF $n^{\circ}$ 2008.72.51.004841-3 SC, Rel. Juiz Fed. Derivaldo de F. B. Filho, julg. 10.5.2010)

Perícia médica por especialista. A perícia deve ser realizada por médico especialista se se trata de doença ou quadro médico complicado, complexo, como, por exemplo, no caso de doença rara. 
(PEDILEF $n^{\circ}$ 2008.72.51.001862-7 SC, Rel. Juiz Fed. Jacqueline Michels Bilhalva, julg. 10.5.2010).

Com efeito, não há qualquer restrição legal para o reconhecimento da incapacidade laborativa pelo Perito Médico Previdenciário ou médico participante de entidade conveniada.

Não obstante, a complexidade da doença pode ensejar a participação de especialista para aferição da incapacidade, sendo certo que se espera que o próprio médico reconheça essa necessidade.

Necessário registrar ainda, que o auxílio-doença é subdividido pela previdência social com a utilização do código B. 31 (auxílio-doença previdenciário ou comum) e pelo código B. 91 (auxílio-doença-acidentário).

\subsection{1. - A apresentação do requerimento de auxílio-doença pelo empregador}

Usualmente, enfrenta-se a questão de que o empregador não teria encaminhado o trabalhador à Previdência Social e que, por essa razão, este teria deixado de ser beneficiário do auxílio-doença.

Há de se indagar, portanto, a obrigatoriedade de apresentação do requerimento do auxílio-doença por parte do empregador e os respectivos efeitos jurídicos dessa situação.

O parágrafo $4^{\circ}$ do artigo 60 da Lei 8.213/91 (na redação da MP 664/2014) dispõe que:

$\S 4$ ํA empresa que dispuser de serviço médico, próprio ou em convênio, terá a seu cargo o exame médico e o abono das faltas correspondentes ao período referido no $\S 3$ ㅇ e somente deverá encaminhar o segurado à perícia médica da Previdência Social quando a incapacidade ultrapassar trinta dias. 
A utilização do verbo "dever" levaria à conclusão simples de que há uma norma impositiva de comportamento para que a empresa realize obrigatoriamente o requerimento do auxílio-doença para o empregado.

Todavia, a sistemática normativa para concessão do auxílio-doença evidencia caminho contrário.

Isso porque a relação jurídica previdenciária, embora inter-relacionada com o contrato de trabalho (no caso do empregado segurado), é autônoma, por ser regrada em regime jurídico e princípios próprios ${ }^{112}$. Não há razão de estabelecer norma de conduta à empresa frente à relação jurídica de que não participa (benefício previdenciário) e da qual sequer tem, em regra, legitimidade jurídica para representar o segurado perante a Previdência Social.

Não se pode olvidar ainda que o artigo 117, I, da Lei 8.213/91 ${ }^{113}$, estabelece a faculdade de convênios entre empresas e INSS para processar o requerimento de benefícios, o que não se coaduna com a interpretação literal de obrigatoriedade do artigo $60, \S 4^{\circ}$.

Reafirmando a facultatividade de a empresa apresentar o requerimento do auxílio-doença, o artigo 76-A do Decreto 3.048/99 dispõe que:

\footnotetext{
${ }_{112}$ Por essas razões, o Supremo Tribunal Federal decidiu que a aposentadoria voluntária não extingue o contrato de trabalho. Confira: EMENTA: Previdência social: aposentadoria espontânea não implica, por si só, extinção do contrato de trabalho. 1. Despedida arbitrária ou sem justa causa $\left(C F\right.$, art. $\left.7^{\circ}, \mathrm{I}\right)$ : viola a garantia constitucional o acórdão que, partindo de premissa derivada de interpretação conferida ao art. 453, caput, da CLT (redação alterada pela L. 6.204/75), decide que a aposentadoria espontânea extingue o contrato de trabalho, mesmo quando o empregado continua a trabalhar na empresa após a concessão do benefício previdenciário. 2. A aposentadoria espontânea pode ou não ser acompanhada do afastamento do empregado de seu trabalho: só há readmissão quando o trabalhador aposentado tiver encerrado a relação de trabalho e posteriormente iniciado outra; caso haja continuidade do trabalho, mesmo após a aposentadoria espontânea, não se pode falar em extinção do contrato de trabalho e, portanto, em readmissão. 3. Precedentes (ADIn 1.721-MC, IImar Galvão, RTJ 186/3; ADIn 1.770, Moreira Alves, RTJ 168/128). RE 449420 / PR - PARANÁ Relator(a): Min. SEPÚLVEDA PERTENCE Julgamento: 16/08/2005 Primeira Turma.

${ }^{113}$ Art. 117. A empresa, o sindicato ou a entidade de aposentados devidamente legalizada poderá, mediante convênio com a Previdência Social, encarregar-se, relativamente a seu empregado ou associado e respectivos dependentes, de:

I - processar requerimento de benefício, preparando-o e instruindo-o de maneira a ser despachado pela Previdência Social;
} 
Art.76-A. É facultado à empresa protocolar requerimento de auxíliodoença ou documento dele originário de seu empregado ou de contribuinte individual a ela vinculado ou a seu serviço, na forma estabelecida pelo INSS. (Incluído pelo Decreto $\mathrm{n}^{\circ} 5.699$, de 13/02/2006 - DOU DE 14/2/2006)

Destarte, ao que transparece do artigo $60, \S 4^{\circ}$, da Lei 8.213/91, é que impede o empregador de encaminhar o segurado à Previdência Social antes do prazo de 15 dias (30 dias após a MP 664/2014), porque somente deve encaminhá-lo após esse período. Da mesma forma, não poderia abonar faltas após o $15^{\circ}$ dia (ou $30^{\circ}$ dia após a MP 664/2014) de afastamento.

Isso, de forma alguma, confunde-se com a obrigatoriedade de requerer auxílio-doença para o empregado.

Por essa razão, não se é possível estabelecer qualquer responsabilidade ao empregador pelo fato exclusivo de não requerer o auxíliodoença para o empregado.

Todavia, a jurisprudência majoritária ainda entende que é dever do empregador o encaminhamento ao INSS, para percepção do benefício previdenciário.

Nesse sentido, transcreve-se parte do seguinte voto:

Assim, verifica-se ser dever do empregador encaminhar o segurado à perícia médica da Previdência Social, o que não ocorreu. Ademais, a CAT emitida pelo empregador (fls. 141/147) e o atestado de fl. 113, emitido por médico do ambulatório da Petrobrás, não apontam a necessidade de afastamento do Autor do trabalho. Ou seja, referida atitude, indubitavelmente, criou obstáculo ao requerimento do benefício previdenciário, pois certamente o mesmo seria indeferido, pois é público e notório o rigor do INSS na concessão de seus benefícios, ainda mais quando o requisito formal (ausência de afastamento superior a 15 dias) não é preenchido por culpa do empregador e da tomadora dos serviços.

( Ag-E-ED-RR - 310400-12.2008.5.09.0594, Relator Ministro: Aloysio Corrêa da Veiga, Data de Julgamento: 02/10/2014, Subseção I Especializada em Dissídios Individuais, Data de Publicação: DEJT 10/10/2014) 
Esse raciocínio leva à conclusão de que a concessão do auxíliodoença não é condição sine qua non para a denominada suspensão do contrato de trabalho, o que veremos no próximo capítulo.

Por ora, necessário registrar a importância de participação do empregador no requerimento do auxílio-doença, justamente para receber a ciência das decisões administrativas referentes ao benefício (art. 76-A do Decreto 8.213/91).

A partir disso poderá se organizar na gestão de pessoas, opor-se às decisões administrativas do INSS e, principalmente, precaver-se da armadilha criada pela alta médica programada realizada pela Previdência Social, reconhecidamente precoce.

\subsection{Situações especiais (empregado em período de carência, aposentado e portador de doença anterior à filiação previdenciária)}

As autonomias das relações jurídicas previdenciária e trabalhista criam situações inusitadas. Veja-se o problema em comento: a relação jurídica previdenciária impede o recebimento de auxílio-doença ao empregado em período de carência, aposentado e ao portador de doença anterior à filiação previdenciária ${ }^{114}$.

A carência é o número mínimo de contribuições mensais indispensáveis para que o beneficiário faça jus ao benefício, consideradas a partir do transcurso do primeiro dia dos meses de suas competências (artigo 24 da Lei 8.213/91).

Segundo o artigo 25, I, da Lei 8.213/91, são necessárias 12 (doze) contribuições mensais para a concessão do auxílio-doença comum ou

$\overline{{ }^{114} \text { Observada a exceção }}$ do artigo 26, II, da Lei 8.213/91. 
previdenciário. O auxílio-doença acidentário não tem carência, nem em razão das doenças e afecções mencionadas no artigo 26, II, da Lei 8.213/91. Assim, o empregado que ainda não tenha completado o período de carência, não receberá o auxílio-doença previdenciário.

O mesmo ocorre com o empregado aposentado, em razão da inacumulatividade do benefício de aposentadoria com auxílio-doença (artigo 124, I, da Lei 8.213/91) ${ }^{115}$ e ao empregado já portador de doença antes da filiação previdenciária, salvo ainda quando a incapacidade sobrevier por motivo de progressão ou agravamento dessa doença ou lesão (artigo 59, parágrafo único, da Lei 8.213/91).

Esses trabalhadores não são submetidos à perícia técnica da autarquia previdenciária porque este procedimento é realizado somente após a fase administrativa de entrega de documentos e verificação do preenchimento dos requisitos legais para o benefício, a qual impede a passagem para a fase seguinte.

Nessas exceções, o reconhecimento da incapacidade laborativa no contrato de trabalho a partir do $16^{\circ}$ dia ( $31^{\circ}$ na redação da MP 664/2014) não ocorrerá como anteriormente estudado.

Por ausência de qualquer norma jurídica específica a respeito, entendemos que o reconhecimento da incapacidade laborativa no contrato de trabalho ocorrerá, por analogia, da mesma forma que prevista para os primeiros 15 dias (ou 30 dias na redação da MP 664/2014).

O que não se pode cogitar, sob pena de evidente discriminação, é entender que as ausências desses trabalhadores nessa situação seriam

\footnotetext{
${ }^{115}$ Registre-se que nos valemos dos mesmos argumentos de Hélio Gustavo Alves de que a contribuição obrigatória do empregado aposentado implica na necessidade de contrapartida da Previdência Social. A negativa reduz a renda familiar do trabalhador e viola o princípio da isonomia entre os segurados. Entendida, pois, se tratar de norma inconstitucional. ALVES, op. cit., 2013, p. 104-108.
} 
injustificadas, porquanto a suspensão contratual deriva da incapacidade laborativa e não, especificamente, da concessão do auxílio-doença. 


\section{CAPÍTULO 4}

\section{EFEITOS DA INCAPACIDADE TEMPORÁRIA NO CONTRATO DE TRABALHO}

\subsection{Suspensão e interrupção do contrato de trabalho}

A incapacidade laborativa causada por doença no contrato de trabalho, conforme anteriormente mencionado, tratava-se de hipótese de justa causa contratual da locação de serviços (artigo 1229, I, do Código Civil de 1916), regra geral para as obrigações de fazer de cumprimento impossível sem culpa do devedor (artigo 879 do Código Civil de 1916 e artigo 248 do atual Código Civil).

Em um segundo momento, a incapacidade por doença não mais era admitida como justa causa para a extinção contratual. Todavia, nada impedia a extinção contratual sem justa causa ${ }^{116}$.

Posteriormente, a evolução dos direitos sociais possibilitou maior proteção do contrato de trabalho durante o período em que o empregado permanecesse incapacitado para o trabalho. A extinção contratual passou a não ser mais tolerada pelo ordenamento jurídico.

Sem o sistema das suspensões contratuais dinâmicas, é certo que o empregado ficaria sem o recebimento de remuneração em diversos casos e, ainda, a rescisão contratual seria acelerada para todo e qualquer caso de tratamento médico. ${ }^{117}$

\footnotetext{
${ }^{116}$ Nesse sentido TST Pleno, proc. 6.329/54, Rev. TST jan-dez 1960: Pode o empregador rescindir o contrato de trabalho cuja execução esteja suspensa em virtude de licença decorrente de auxílioenfermidade concedido por instituição de previdência. Apud LINS, Edilberto Quintela Vieira. Incapacidade Executiva de Trabalho e Contrato de Emprego.

${ }_{117}$ SILVA, op. cit., 2013. vol. 1, p. 202.
} 
Por essa razão, desenvolveu-se a teoria da suspensão do contrato de trabalho ${ }^{118}$, que tem como fundamento axiológico a ideia de estabilidade do trabalhador $^{119}$ :

... tem por objetivo proteger, isto é, os interesses do empregado, por ser uma aplicação da ideia de estabilidade, como medida cujo propósito é fortalecer a estabilidade, relevando temporariamente o empregado do cumprimento de suas obrigações, sem que este incorra em responsabilidade, como consequência da suspensão desta obrigação de fazer (de executar o serviço)... ${ }^{120}$

Uma tendência profundamente tuitiva do trabalhador foi-se manifestando e levou à procura de formas jurídicas que permitissem ao empregado, quando temporariamente impossibilitado por força maior de cumprir com as obrigações oriundas do contrato de trabalho, continuar ligado ao seu empregador pelo mesmo vínculo jurídico. ${ }^{121}$

Debruçando-se sobre a questão, a doutrina passou identificar diferenças entre a suspensão total e suspensão parcial (também denominada interrupção) do contrato de trabalho:

...consiste a suspensão na não prestação de serviços pelo empregado, sem direito à percepção de salários a que teria direito se estivesse trabalhando, durante o período de suspensão. A interrupção do contrato de trabalho, ao contrário, importando embora em não prestação de serviços pelo empregado durante algum tempo, não acarreta a perda do direito à percepção do salário, durante o tempo da interrupção. ${ }^{122}$

Outra diferença entre a suspensão total e a interrupção (ou suspensão parcial) é que não se computa o tempo da suspensão total no tempo de serviço, enquanto que o tempo de serviço na interrupção é computado ${ }^{123}$.

118 Orlando Gomes e Elson Gottschalk afirmam que a "paralisação da relação de emprego se denomina tecnicamente suspensão do contrato de trabalho". Antonio Lamarca chegou a afirmar que "na suspensão, o contrato sofre uma revogação parcial". O destaque desses antigos posicionamentos doutrinários é relevante para que se compreenda a dificuldade há muito encontrada com a suspensão do contrato de trabalho.

GOMES, Orlando; GOTTSCHALK, Elson. Curso de Direito do Trabalho. 14. ed. Rio de Janeiro: Forense, 1997.

${ }^{119}$ Nesse sentido: CARDONE, op. cit., 2011, p.100, apud TOSHIO YAMAGUCHI. La théorie de la suspension du contrat de travail.

${ }^{120}$ MACHADO FILHO, Sebastião. Suspensão do Contrato de Trabalho e outros estudos. 1. ed. São

Paulo: Ltr, 1986, p. 16.

${ }^{121}$ CARDONE, op. cit., 2011, p. 100.

${ }^{122}$ CESARINO JR., op. cit., 1956, p. 245.

${ }^{123}$ MACHADO FILHO, op. cit., 1986, p. 14. 
Em verdade, nem isso é correto, eis que o artigo 60 do Decreto 3.048/99 e o artigo 164, XVI, da IN INSS/PRES no 77, de 21/01/2015, estabelecem que o período em que o segurado percebe benefício previdenciário por incapacidade também é considerado tempo de contribuição.

O tempo de serviço a que se refere a doutrina, portanto, é aquele para efeitos de estabilidade e indenização (artigo 4ํㅜㄹ parágrafo único, da CLT) e depósitos de FGTS (artigo 15, §5을 da Lei 8.036/90).

Ensina a doutrina que não é, efetivamente, o contrato de trabalho que se suspende, mas tão somente seus efeitos.

Quando todos os efeitos contratuais desaparecem, mas não em caráter definitivo - quando desaparecem provisoriamente, para que renasçam algum tempo após, dá-se a suspensão do contrato de trabalho. Às vezes, não há, propriamente, cessação transitória dos efeitos do contrato. Cessam, apenas, alguns desses efeitos. Em circunstância também especial e expressamente consignada pelo direito positivo, o trabalhador fica desobrigado de executar serviços para seu patrão, sendo que, no entanto, o empregador não se exime de pagar ao obreiro, total ou parcialmente, a remuneração combinada. Dá-se, agora, a interrupção do contrato individual de trabalho ${ }^{124}$.

A classificação doutrinária não deixa de sofrer pertinentes críticas:

Preferimos sustentar que melhor seria uma só figura, a suspensão, em vez de duas figuras, suspensão e interrupção. Não há validade científica nessa distinção. Seus efeitos são apenas didáticos. Não é correto também dizer suspensão do contrato, expressão que mantemos porque assim é na doutrina preponderante. O contrato não se suspende. Suspende-se sempre o trabalho, tanto nas denominadas suspensões como nas interrupções. Suspenso o trabalho, haverá alguns efeitos jurídicos. Esses efeitos são variáveis. Referem-se ao salário em algumas hipóteses mantido e em outras não, ao recolhimento dos depósitos de Fundo de Garantia, à contagem do tempo de serviço para fins de indenização, à contagem dos períodos aquisitivos de férias, etc. ${ }^{125}$

\footnotetext{
${ }^{124}$ RUSSOMANO, Mozart Victor. Comentários à Consolidação das Leis do Trabalho. 4. ed.; Rio de Janeiro: Revista dos Tribunais, 1977, p. 223.

${ }^{125}$ NASCIMENTO, Amauri Mascaro. Curso de Direito do Trabalho. 20. ed. São Paulo: Saraiva, 2005, p. 221.
} 
Também percorrendo este último raciocínio jurídico, há entendimento doutrinário no sentido de que não ocorre a suspensão ou interrupção do contrato de trabalho ou de seus efeitos, como definido usualmente pela doutrina, mas apenas a "suspensão da prestação de fazer no contrato de trabalho":

\begin{abstract}
A lei não pode reconhecer os efeitos de um contrato suspenso se, antes, o reconhece suspenso, isto é, sem vigência; ou, em outras palavras, não pode impor que as partes cumpram determinada conduta decorrente do contrato suspenso quando, ao mesmo tempo, reconhece que, não estando em vigência o contrato, as partes estão desobrigadas de prestar essa mesma conduta. Seria uma contradição que a lei tem por função obviar. Ora, se a lei conferisse efeitos jurídicos ao contrato, então seria esse o primeiro indício de que não se trata de suspensão do contrato, porque a produção daqueles efeitos depende logicamente da vigência deste. ${ }^{126}$
\end{abstract}

Segundo essa teoria, a suspensão da prestação de fazer não corresponderia à suspensão da obrigação de dar, inerente ao dever do empregador:

Não há fundamento jurídico que autorize a suspensão das prestações do empregador, correspondentes ao pagamento do salário e ao cômputo do tempo de serviço efetivo, durante a suspensão da prestação de fazer. Bastaria observar que essa suspensão só o é de uma prestação: a do empregado (de fazer ou de executar o serviço) ${ }^{127}$

Com efeito, resssalvadas algumas exceções, não existe norma jurídica que correlacione a suspensão da execução do serviço do empregado com a ausência do pagamento de salário ou demais vantagens por parte do empregador.

Por óbvio, o contrato de trabalho tem como principal obrigação a prestação de serviços com a respectiva contraprestação de pagamento. Todavia, não se pode levar à conclusão automática de que a inexistência da primeira implique, necessariamente, na inexistência da segunda. Isso ocorre porque

${ }^{126}$ MACHADO FILHO, op. cit., 1986, p. 66.

${ }^{127}$ Ibidem, p. 89. 
somente há a suspensão da obrigação de fazer que decorre de norma cogente do ordenamento jurídico.

A suspensão da prestação de fazer, como prestação de não-fazer do empregado, é conteúdo institucional, porque determinado obrigatoriamente em todo contrato de emprego, por força de normas jurídicas cogentes de ordem pública, isto é, as partes, além de não poderem regulá-lo de acordo com seus interesses particulares, são obrigadas a aceitá-lo como já formando parte do conteúdo do contrato de emprego, não tendo o poder de derrogá-lo. ${ }^{128}$

Nos casos de afastamento por auxílio-doença, essa teoria entende que as "rendas mensais recebidas pelo empregado, cuja natureza jurídica se esteia na teoria do salário diferido, substituem e excluem, assim, o pagamento do salário diretamente pelo empregador". ${ }^{129}$

Esse entendimento doutrinário, que adotamos, mostra-se muito interessante quando o operador do direito passa a analisar outras prestações do contrato de trabalho, como: o dever de lealdade (sigilo funcional, nãoconcorrência desleal), o dever de proteção (segurança e medicina do trabalho), a aquisição de direito de garantia do emprego (artigo 118 da Lei 8.213/91) e, mais recentemente, o dever de manutenção do plano de saúde (Súmula 440 do TST) .

Ainda que interrompido ou suspenso, alguns efeitos permanecem existindo, como consequências das obrigações acessórias. A boa-fé, lealdade, honestidade, dever de sigilo, etc, continuam sendo exigidos. Tratam-se de deveres recíprocos, que devem ser mantidos tanto pelo empregado, como pelo empregador. ${ }^{130}$

Não se pode negar que essas prestações obrigacionais permanecem intocáveis e demonstram a vigência de efeitos do contrato de trabalho durante a suspensão da obrigação de fazer de prestar serviços por parte do empregado. Cabe recordar ensinamento clássico de que o sinalagma do contrato de trabalho não se opera prestação por prestação, mas por todo o conteúdo obrigacional que ele envolve.

\footnotetext{
${ }^{128}$ Ibidem, p. 87.

129 Ibidem, p. 101.

${ }^{130}$ MUSSI, Cristiane Miziara. Os efeitos do recebimento dos benefícios previdenciários no contrato de trabalho. Doutorado em Direito Previdenciário. São Paulo: Pontifícia Universidade Católica, 2007, p. 171.
} 
...mais adequado atribuir ao salário a natureza de retribuição paga ao empregado não só pelos serviços prestados, mas pelo fato de colocar-se à disposição do empregador, subordinando-se ao plano da organização do trabalho alheio e nele baseando sua existência. Isso não exclui o fato de o salário, em geral, encontrar-se vinculado, em grande parte, ao trabalho efetivamente prestado. ${ }^{131}$

Salário é o conjunto de parcelas contraprestativas pagas pelo empregador ao empregado em função do contrato de trabalho. ${ }^{132}$

Como demonstrado, observa-se que não tem rigor jurídico o congelamento automático de todos os efeitos contratuais pela incapacidade laborativa temporária decorrente de doença.

Não obstante a essas considerações, em razão da denominação usualmente aceita, utilizaremos o termo suspensão contratual no presente estudo, tal qual se rendeu Edilberto Quintela Vieira Lins:

\begin{abstract}
Daí porque se costuma dizer que a suspensão não tem caráter global e não se poderia mesmo falar, com precisão e rigor técnico, em uma suspensão do contrato, pois que apenas ocorre a suspensão da prestação de trabalho, acarretando, por aplicação do princípio da exceptio non adimplenti contractus, a suspensão do pagamento do salário com a de alguns outros efeitos. Mas a expressão já se acha consagrada entre nós e na doutrina estrangeira, encerrando, não obstante, a noção de que obrigações e direitos secundários permanecem e continuam a produzir efeitos. ${ }^{133}$
\end{abstract}

Recorde-se que, no estudo dos contratos bilaterais ou sinalagmáticos, ensina Orlando Gomes ${ }^{134}$ que a exceção de contrato não cumprido (exceptio non adimplenti contractus) e a cláusula resolutiva tácita são as características que justificam a diferenciação entre contratos bilaterais e unilaterias, porquanto não são aplicáveis a estes últimos, conforme adotado pelo Código Civil (artigos 475 e 476$)$.

${ }^{131}$ BARROS, op. cit., 2010, p. 714.

${ }^{132}$ DELGADO, Mauricio Godinho, op. cit., 2006, p. 681.

${ }^{133}$ LINS, op. cit., 1984, p. 141.

${ }^{134}$ GOMES, Orlando. Contratos. 21. ed. Rio de Janeiro: Forense, 2000, p. 72 e 91. 
Pelas razões tuitivas inerentes ao contrato de trabalho, a suspensão do contrato de trabalho compreendeu-se a necessidade de afastamento da cláusula resolutiva tácita, impedindo a rescisão contratual (artigo 471 da CLT). Por essas mesmas razões, acrescentadas pela vigência de diversas prestações (principalmente negativas) inerentes ao contrato de trabalho por parte do empregado, que deve ser analisado pelo todo e não por cada prestação, também não há compatibilidade da suspensão contratual trabalhista com o preceito civilista de exceção de contrato não cumprido na hipótese.

Por essas mesmas razões, é indiscutível a suspensão do contrato de trabalho do empregado doméstico, bem como sua incompatibilidade também com a cláusula resolutiva tácita civilista, em que pese não ser alcançado pelos efeitos do artigo 471 da CLT (garantido os direitos após retorno ao trabalho), por força do artigo $7^{\circ}$, "a", desse mesmo diploma legal.

\subsection{A suspensão contratual decorrente da incapacidade laborativa}

O artigo 476 da CLT dispõe que:

Art. 476 - Em caso de seguro-doença ou auxílio-enfermidade, o empregado é considerado em licença não remunerada, durante o prazo desse benefício.

No mesmo sentido, o artigo 63 da Lei 8.213/91, estabelece que:

Art. 63.0 segurado empregado em gozo de auxílio-doença será considerado pela empresa como licenciado.

Os dispositivos legais transcritos deixam claro que o empregado é considerado como licenciado quando percebe benefício previdenciário de auxíliodoença, o que ocorre a partir do $16^{\circ}$ dia (ou $31^{\circ}$ dia na redação da MP 664/2014).

Entretanto, necessário indagar nesse momento, se a percepção do benefício previdenciário é condição sine qua non para a suspensão da prestação de serviços pelo empregado. 
Como anteriormente transcrito, não se pode ignorar que a percepção do auxílio-doença é, em regra, o reconhecimento da incapacidade laborativa para a ocorrência da suspensão da prestação de serviços (a usualmente denominada suspensão contratual).

Todavia, parece-nos que a existência da incapacidade laborativa do empregado é o verdadeiro requisito indispensável para que ocorra a suspensão contratual.

O impedimento fortuito ${ }^{135}$ da prestação de serviço não pode the acarretar prejuízo contratual em consequência da situação, porquanto a obrigação se torna de impossível cumprimento nesse período.

Observem-se, por exemplo, o empregado ainda sujeito à carência da lei previdenciária ${ }^{136}$ ou aposentado ${ }^{137}$, que estão impedidos de receber o auxíliodoença previdenciário.

O mesmo ocorre com o empregado que tem seu auxílio-doença indeferido por não constatada a incapacidade laborativa pela autarquia previdenciária, mas que não está apto para retornar ao trabalho.

Essas situações de incapacidade laborativa implicam no reconhecimento da suspensão contratual e, por conseguinte, subtraem o direito de extinção contratual sem justa causa, por iniciativa do empregador, ainda que não haja concessão do auxílio-doença pela previdência social.

\footnotetext{
${ }^{135}$ Ensina Orlando Gomes: "Todo o fato alheio à vontade do devedor, que o impossibilite de cumprir a obrigação, considera-se caso fortuito, para o efeito de exonerá-lo de responsabilidade". GOMES, Orlando. Obrigações. 12. ed. Rio de Janeiro: Forense, 1999, p. 149.

${ }^{136}$ Lei 8.213/91: Art. 25. A concessão das prestações pecuniárias do Regime Geral de Previdência Social depende dos seguintes períodos de carência, ressalvado o disposto no art. 26: I - auxíliodoença e aposentadoria por invalidez: 12 (doze) contribuições mensais;

137 Lei 8.213/91: Art. 124. Salvo no caso de direito adquirido, não é permitido o recebimento conjunto dos seguintes benefícios da Previdência Social: I - aposentadoria e auxílio-doença;
} 
Passaremos a estudar, a seguir, as consequências da incapacidade laborativa temporária por doença no contrato de trabalho.

\subsubsection{Prescrição}

Outra questão que muito se debateu diz respeito ao prazo prescricional no curso da suspensão do contrato de trabalho.

Há entendimento de que o prazo prescricional se suspenderia em conjunto com o contrato de trabalho, a denominada teoria da dupla suspensão.

Segundo esse entendimento, o prazo prescricional não correria enquanto o contrato de trabalho permanecesse suspenso, sob o fundamento de que penderia uma condição suspensiva (artigo 199, I, do Código Civil), ${ }^{138}$ por questões que rodeiam o trabalhador quando enfermo ${ }^{139}$.

O art. 199, I, do CC, que afirma não correr igualmente a prescrição, "pendendo condição suspensiva", tem sido o fundamento de algumas decisões da Justiça do trabalho, que consideram o auxílio-doença e a aposentadoria por invalidez condições suspensivas, que impediriam o curso do prazo prescricional. Todavia, a exata interpretação da expressão do inciso I, do art. 199, diz que a condição suspensiva deve referir-se à aquisição do direito subjetivo, ao qual corresponderia uma pretensão se ele fosse violado, pretensão esta que poderia ser fulminada pela prescrição. ${ }^{140}$

Entretanto, o pensamento que prevalece na doutrina e jurisprudência é no sentido de que a suspensão do prazo prescricional não se suspende em decorrência da suspensão do contrato de trabalho, apenas ocorrendo na forma prevista em lei. Nesse sentido:

Estar enfermo sabidamente atrasa os compromissos e embaça a vida cotidiana, mas é pueril sustentar que impeça a pessoa de procurar

\footnotetext{
${ }^{138}$ A condição suspensiva, deriva da vontade das partes (artigo 121 do Código Civil) e, enquanto não se verificar, não se terá adquirido o direito (artigo 125 do Código Civil). Não se cogita prazo prescricional (que representa a perda do direito de exigir judicialmente determinada prestação) sobre direito sequer adquirido e que não derive de exclusiva vontade das partes. Nossa hipótese não se trata, pois, de condição suspensiva.

139 CARRION, Valentin. Comentários à Consolidação das Leis do Trabalho. 24. ed. São Paulo: Saraiva, 1999.

${ }^{140}$ CARDONE, op cit., 2011, p. 131.
} 
um advogado, acessar uma entidade sindical ou procurar assistência judiciária em geral. Mesmo enfermo, o trabalhador continua a ter de prestar contas à Previdência Social, inclusive submetendo-se às perícias, por exemplo, não havendo motivo para se dizer que à Justiça do Trabalho ele não possa comparecer. Logo, a suspensão do contrato de trabalho por motivo de enfermidade, mediante auxíliodoença acidentário ou auxílio-doença meramente previdenciário, em nada deve ser confundida com a suspensão da fluência dos prazos prescricionais. Excepciona-se, evidentemente, a rara hipóteses de o empregado estar privado de suas faculdades mentais... ${ }^{141}$

A Orientação Jurisprudencial 375 da Seção de Dissídios Individuais-I do TST pacificou a jurisprudência de acordo com esse segundo entendimento:

375. Auxílio-doença. Aposentadoria por invalidez. Suspensão do contrato de trabalho. Prescrição. Contagem. (Divulgada em 19/04/2010 e publicada DeJT 20.04.2010)

A suspensão do contrato de trabalho, em virtude da percepção do auxílio-doença ou da aposentadoria por invalidez, não impede a fluência da prescrição quinquenal, ressalvada a hipótese de absoluta impossibilidade de acesso ao Judiciário.

A absoluta impossibilidade de acesso ao Judiciário deve ser analisada, concretamente, de acordo com artigo 198, I, e do artigo $3^{\circ}$, I e II, ambos do Código Civil:

Art. 198. Também não corre a prescrição:

I - contra os incapazes de que trata o art. $3 \underline{0}$;

Art. $3^{\circ}$ São absolutamente incapazes de exercer pessoalmente os atos da vida civil:

II - os que, por enfermidade ou deficiência mental, não tiverem o necessário discernimento para a prática desses atos;

III - os que, mesmo por causa transitória, não puderem exprimir sua vontade.

Nessas situações, a prescrição permanece suspensa e retoma sua contagem (pelo prazo remanescente) após cessadas as hipóteses prevista expressamente nesses dispositivos legais.

Eduardo Gabriel Saad, apresenta ainda determinada distinção na contagem do prazo prescricional, em razão da redação do artigo 471 da CLT:

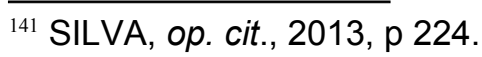


Enquanto suspenso o contrato de trabalho, não corre a prescrição na hipótese de vantagens concedidas durante o curso do afastamento do empregado por motivo de doença ou acidente de trabalho. Diz o artigo em epígrafe que tais vantagens são asseguradas ao empregado "por ocasião de sua volta". Logo, é a partir do retorno ao serviço que começa a fluir o prazo prescricional.

Contudo, se a ação se referir a direitos e vantagens concedidos antes do afastamento do empregado por motivo de doença e acidentário, ou não, a jurisprudência do TST tem sido no sentido de que inexiste a suspensão do prazo prescricional ${ }^{142}$.

Essa distinção se coaduna com a Teoria da Actio nata, porquanto as violações aos direitos do empregado com o contrato de trabalho suspenso somente ocorrem quando retorna ao trabalho, momento em que devem ser adimplidas as obrigações asseguradas pela norma.

Entretanto, a distinção perde qualquer significado relevante, pois se a prestação obrigacional somente é devida após o retorno ao trabalho, não haveria que se falar em prazo prescricional que possa ocorrer antes do vencimento da obrigação, momento em que o direito ainda não teria sido violado.

Suspensa tão somente a obrigação de fazer consistente em prestar serviços, como defendemos, nada impede que se constate a violação de direitos durante a suspensão contratual e, por conseguinte, flua o prazo prescricional.

\subsubsection{Férias}

O artigo 131, III, da CLT dispõe que:

Art. 131 - Não será considerada falta ao serviço, para os efeitos do artigo anterior, a ausência do empregado: (Redação dada pelo Decreto-lei n 1.535, de 13.4.1977)

III - por motivo de acidente do trabalho ou enfermidade atestada pelo Instituto Nacional do Seguro Social - INSS, excetuada a hipótese do inciso IV do art. 133; (Redação dada pela Lei nº 8.726, de 5.11.1993)

${ }^{142}$ SAAD, Eduardo Gabriel. Consolidação das Leis do Trabalho Comentada. 47. ed. São Paulo: Ltr, 2014, p. 625. 
Esse dispositivo esclarece que os afastamentos não são considerados faltas para efeitos da redução do número de dias das férias previstas no artigo 130 da CLT. Embora a norma imponha como requisito o atestamento pelo INSS, os dias iniciais em que as faltas são abonadas pelo empregador (artigo 60, $\S 4^{\circ}$, da Lei 8.213/91) também não são consideradas faltas para a contagem do artigo 130 da CLT, porquanto esse abono inicial de faltas é pressuposto fático da posterior concessão do auxílio-doença.

O afastamento do empregado por mais de seis meses, embora descontínuos, ocasiona a perda do direito à aquisição das férias correspondentes ${ }^{143}$, reiniciando-se novo período aquisitivo a partir de seu retorno ao trabalho:

Art. 133 - Não terá direito a férias o empregado que, no curso do período aquisitivo: (Redação dada pelo Decreto-lei $\mathrm{n}^{\circ} 1.535$, de 13.4.1977)

IV - tiver percebido da Previdência Social prestações de acidente de trabalho ou de auxílio-doença por mais de 6 (seis) meses, embora descontínuos. (Incluído pelo Decreto-lei nº 1.535, de 13.4.1977)

$\S 2^{\circ}$ - Iniciar-se-á o decurso de novo período aquisitivo quando o empregado, após o implemento de qualquer das condições previstas neste artigo, retornar ao serviço. (Incluído pelo Decreto-lei $n^{\circ} 1.535$, de 13.4.1977)

Note-se que o referido dispositivo legal impõe algumas condições para a perda do direito às férias: a) perceber prestações da Previdência Social de acidente de trabalho ou de auxílio-doença; b) por período maior que 6 meses, embora descontínuos; e c) no mesmo período aquisitivo.

\footnotetext{
${ }^{143}$ Registra-se entendimento doutrinário no sentido de que o artigo 5, item 4, da Convenção $n^{\circ} 132$ da OIT teria derrogado o artigo 133, IV, da CLT. A mencionada norma dispõe que: 4. - Nas condições a serem determinadas pela autoridade competente ou pelo órgão apropriado de cada país, as faltas ao trabalho por motivos independentes da vontade individual da pessoa empregada interessada tais como faltas devidas a doenças, a acidente, ou a licença para gestantes, não poderão ser computadas como parte das férias remuneradas anuais mínimas previstas no parágrafo 3 do Artigo 3 da presente Convenção. A nosso entender, a norma não tem dimensão mais restrita que o artigo $130, \S 1^{\circ}$, da CLT: $\S 1^{\circ}$ - É vedado descontar, do período de férias, as faltas do empregado ao serviço. Não se pode confundir a limitação à aquisição do direito às férias (hipótese do artigo 133, IV, da CLT) com a contagem de dias de sua fruição (artigo 130, $\S 1^{\circ}$, da CLT e artigo 5, item 4, da Convenção 132 da OIT).
} 
De plano, pode-se observar que a lei impõe limite à aquisição de férias para aquele que percebe prestações da Previdência Social por mais de seis meses.

O período em que o empregador abona as faltas (os 15 primeiros dias ou 30 primeiros dias a partira da vigência da MP 664/2014) não é prestação da previdência social e, portanto, não pode ser considerado para esse efeito. Por restringir direitos, não pode produzir efeitos além da subsunção prevista na regra.

Requisito que se passa despercebido é que o afastamento por período maior que seis meses, embora descontínuos, deve ocorrer no curso do mesmo período aquisitivo, em razão do disposto no caput do artigo 133 da CLT (no curso do período aquisitivo).

O afastamento em decorrência da incapacidade laborativa até 6 meses no mesmo período aquisitivo, não afeta o direito às férias ou quando o afastamento supera 6 meses, mas em períodos aquisitivos diferentes.

Quanto à concessão das férias, novos problemas podem ocorrer.

O primeiro diz respeito ao período concessivo previsto no artigo 134 da CLT e a cominação do artigo 137 CLT quanto à violação:

Art. 134 - As férias serão concedidas por ato do empregador, em um só período, nos 12 (doze) meses subseqüentes à data em que o empregado tiver adquirido o direito. (Redação dada pelo Decreto-lei $\mathrm{n}^{\circ}$ 1.535, de 13.4.1977)

Art. 137 - Sempre que as férias forem concedidas após o prazo de que trata o art. 134, o empregador pagará em dobro a respectiva remuneração. (Redação dada pelo Decreto-lei $n^{\circ} 1.535$, de 13.4.1977) 
O afastamento do empregado por motivo de saúde pode impedir a concessão das férias pelo empregador no prazo legal. Esse impedimento fortuito $^{144}$ não pode lhe acarretar a consequência do inadimplemento, porquanto a obrigação era de impossível cumprimento no período do afastamento.

As férias, portanto, só serão gozadas e pagas quando do convalescimento do contrato, sendo evidente que não tem aplicação o disposto no artigo 137 consolidado, referente ao pagamento em dobro da remuneração em férias, e o estabelecido no seu $\S^{\circ}$, que faculta o empregado, vencido o prazo de concessão, ajuizar reclamação pedindo a fixação, por sentença, da época do gozo das férias. ${ }^{145146}$

A concessão das férias, in casu, subordina-se à condição suspensiva do contrato (gozo de auxílio-doença), o que impede, enquando o afastamento durar, o pagamento em dobro (art. 137 da CLT), o pedido de fixação, por sentença, da época de gozo (art. 137, $\S 1^{\circ}$ ), a antecipação ao abono pecuniário (arts. 143 e 145 da CLT) e o curso da prescrição (arts. 149, da CLT e 170, I, do CC). ${ }^{147}$

O ordenamento jurídico formulou um sistema de aquisição e concessão de férias que tem como premissa a vedação de acumulação de dois períodos de férias, ou seja, as férias em dobro ocorrem quando o empregador não concede uma das férias antes da aquisição de novo período de férias (artigos 130 e 134 da CLT).

Parece-nos que essa limitação temporal (impedimento de acumulação de dois períodos de férias) é parâmetro a ser respeitado, ainda por determinação da concessão anual de férias (artigo 129 da CLT). Logo, competirá ao empregador a concessão das férias antes da aquisição de novo período.

\footnotetext{
${ }^{144}$ Ensina Orlando Gomes: "Todo o fato alheio à vontade do devedor, que o impossibilite de cumprir a obrigação, considera-se caso fortuito, para o efeito de exonerá-lo de responsabilidade" Vide GOMES, op. cit., 1999, p. 149.

${ }_{145}$ LINS, op. cit., 1984, p. 68.

${ }^{146}$ Discorda-se do fundamento desse autor (LINS, 1984, p.68) no sentido de que a concessão das férias depende de uma condição suspensiva. A condição deriva exclusivamente da vontade das partes (Artigo 121 do Código Civil). As condiciones iuris (condições da lei) são necessárias, inerentes à natureza do ato, como exemplo, um comodato gratuito. Não se trata, pois, de condição suspensiva, mas de impontualidade por força externa à vontade do devedor.

${ }^{147}$ ALLY, Raimundo Cerqueira. Normas Previdenciárias no Contrato de Trabalho. São Paulo: IOB, 2002, p. 102.
} 
Nos casos em que a acumulação é inevitável em razão do período do contrato de trabalho e largo período da incapacidade laborativa, as férias deverão ser concedidas imediatamente (porquanto o fortuito se extinguiu), sob pena de a impontualidade ser considerada culposa por parte do empregador.

As férias que o segurado tinha direito antes do recebimento do auxílio-doença, só poderão ser gozadas após a extinção do fato que deu ensejo à suspensão do contrato de trabalho, ou seja, após cessar o recebimento do benefício previdenciário pelo empregador. ${ }^{148}$

Admitida a prorrogação do período concessivo conforme acima, evidente que a prescrição das férias somente ocorrerá a partir de seu término (artigo 149 da CLT), segundo aplicação da teoria da actio nata.

Finalmente, resta analisar a situação em que o empregado passa a ficar incapacitado durante o período de férias, isto é, ocorre a incapacidade laborativa superveniente ao início das férias. A lei brasileira é silente a respeito.

O artigo $6^{\circ}$, item 2, da Convenção 132 da OIT, estabelece que:

2 - Em condições a serem determinadas pela autoridade competente ou pelo órgão de cada país, os períodos de incapacidade para o trabalho resultante de doença ou de acidentes não poderão ser computados como parte do período mínimo de férias anuais previsto no $\S^{\circ}$, do artigo $3^{\circ}$ da presente Convenção.

Por sua vez, o mencionado dispositivo determina que:

3 - A duração das férias não deverá em caso algum ser inferior a 3 (três) semanas de trabalho, por 1 (um) ano de serviço.

Diante dessas normas, há entendimento de que o "empregador deverá suspender o gozo das férias quando da ocorrência de afastamento médico"149, com o que não concordamos indistintamente. ${ }^{150}$

\footnotetext{
${ }^{148}$ MUSSI, op. cit., 2007, p. 272.

${ }^{149}$ VIANNA, Cláudia Salles Vilela, op.cit., 2010, p. 63.

${ }_{150}$ Sem adentrar na questão de superioridade hierárquica da norma internacional (Teoria da Supralegalidade dos Tratados Internacionais de Direitos Humanos - vide julgamento do STF - RE 466.343/SP), não há como deixar de registrar que o instituto férias vem sendo tratado pela
} 
Inicialmente, esclareça-se que as normas estabelecem sua eficácia à fixação de condições a serem determinadas pela autoridade competente ou pelo órgão de cada país, o que inexiste no ordenamento jurídico brasileiro. Não obstante, a norma é clara ao atribuir eficácia às garantidas mínimas a serem implementadas.

Em segundo plano, somente se pode cogitar a aplicabilidade do referido entendimento caso não seja garantido o período mínimo de férias estabelecido na Convenção (três semanas), como determina o próprio dispositivo. Considerando que as férias no Brasil são, em regra, de 30 (trinta) dias, verifica-se que as incapacidades laborativas até 9 (nove) dias não afetariam a contagem das férias, porque garantido o período mínimo daquele instrumento normativo internacional (três semanas são 21 dias). Para as incapacidades laborativas a partir de 10 (dez) dias durante as férias, realmente há a necessidade de recompor os dias para garantia do período mínimo de três semanas completas (21 dias de descanso), mas não há a obrigatoriedade de suspensão e retomada seguinte do gozo das férias, caso possível sua partição em outro período.

Ressalvam-se, obviamente, as férias parcialmente adquiridas em razão de faltas injustificadas (artigo 130 da CLT) e a do trabalhador em tempo parcial (artigo 130-A da CLT). Por questão de equidade e de utilização da proporcionalidade, pode-se conceber que a incapacidade laborativa superveniente de até $30 \%$ das férias em gozo não necessitam de recomposição. Acima disso, os dias remanescentes devem creditados ao trabalhador, a fim de se garantir o descanso em $70 \%$ do período (tal qual a proporção 21 dias para 30 dias da regra geral).

A partição do período das férias, isto é, creditar ao trabalhador dias de férias a serem gozadas para a garantia mínima da Convenção 132 da OIT, com a imediata cessação das férias, é a única forma que se coaduna com a sistemática Acumulação entre as normas da CLT e da Convenção n 132 da OIT. Vide Súmula 261 do TST. 
previdenciária estabelecida pela IN INSS/PRES nº 77, de 21 de janeiro de 2015, que prevê em seu artigo $303, \S 2^{\circ}$, que no caso da data de início da incapacidade do segurado ser fixada quando este estiver em gozo de férias ou licença-prêmio ou qualquer outro tipo de licença remunerada, o prazo de quinze dias (ou trinta dias após MP 664/2014) de responsabilidade da empresa, será contado a partir do dia seguinte ao término das férias ou da licença.

Finalmente, não se pode olvidar a existência do verbete de Súmula 46 do TST, aprovada em 14 de abril de 1964 e mantida na revisão da comissão de jurisprudência do TST no ano de 2003, prevê que:

46 - Acidente de trabalho (RA 41/1973, DJ 14.06.1973)

As faltas ou ausências decorrentes de acidente do trabalho não são consideradas para os efeitos de duração de férias e cálculo da gratificação natalina.

Os julgamentos utilizados como precedentes dessa súmula não são esclarecedores, além de não se relacionarem com a nova sistemática previdenciária de cobertura do acidente do trabalho, conforme veremos no item a seguir.

Há entendimento, inclusive, que o verbete sumular restou superado pela nova redação ao capítulo de férias da CLT, da 1977:

Tal orientação tornou-se ultrapassada com o advento do Decreto-Lei 1.535, de 13.05.77, que deu nova feição ao capítulo de férias da CLT. ${ }^{151}$

\subsubsection{Gratificação natalina $\left(13^{\circ}\right.$ salário $)$}

O artigo $1^{\circ}$ e o artigo $2^{\circ}$ da Lei $4.090 / 62$ estabelecem que:

Art. $1^{\circ}$ - No mês de dezembro de cada ano, a todo empregado será paga, pelo empregador, uma gratificação salarial, independentemente da remuneração a que fizer jus.

${ }^{151}$ ALLY, op. Cit., 2002, p. 101. 
$\S 1^{\circ}$ - A gratificação corresponderá a $1 / 12$ avos da remuneração devida em dezembro, por mês de serviço, do ano correspondente.

Art. $2^{\circ}$ - As faltas legais e justificadas ao serviço não serão deduzidas para os fins previstos no $\S 1^{\circ}$ do art. $1^{\circ}$ desta Lei.

A doutrina especializada oscila a respeito do tema.

Há entendimento de que o afastamento do empregado em razão de incapacidade laborativa é justificada legalmente e, portanto, não afetaria o direito à gratificação natalina:

Como as faltas por incapacidade, que geram auxílio-doença, são legais, nenhuma outra cogitação será necessária para concluir que efeito algum elas terão sobre o cálculo do valor da referida gratificação de Natal. ${ }^{152}$

Outra linha de pensamento compreende que não é devida a gratificação natalina no período de percepção do auxílio-doença diante da inexistência da prestação de serviços exigida no diploma legal:

A Lei $n^{\circ} 4.090$, de 13 de julho de 1962, que a instituiu, estabeleceu que a gratificação corresponderá a $1 / 12$ da remuneração devida em dezembro, por mês de serviço do ano correspondente... Como se verifica, a gratificação é devida por mês de serviço, ou por dias de trabalho somando pelo menos uma quinzena, situações que não se visualizam quando o contrato está suspenso, pois que o período de suspensão não integra o tempo de serviço do empregado. ${ }^{153}$

O segundo entendimento parece-nos mais adequado. Acrescente-se que o empregado em gozo do auxílio-doença é considerado em licença sem remuneração (art. 476 da CLT e artigo 63, caput, da Lei 8.213/91). Esse período não é tratado pelo ordenamento jurídico, especificamente, como falta legal (artigo 473 da CLT), em que há a garantia da remuneração ao empregado. Não incide, pois, a regra do artigo $2^{\circ}$ da Lei 4.090/62 à hipótese.

Ademais, o sistema previdenciário garante o recebimento do abono anual (13 $13^{a}$ prestação anual de remuneração do benefício previdenciário) na forma

${ }_{152}$ CARDONE, op. cit., 2011, p. 104.

${ }^{153}$ LINS, op. cit., 1984, p. 70. 
do artigo 40 da Lei $8.213 / 91^{154}$. Inusitado seria que o empregado licenciado recebesse a gratificação natalina com o contrato de trabalho suspenso e, ao mesmo tempo, o abono anual da previdência social.

\begin{abstract}
No que se refere ao $13^{\circ}$ salário, o empregador não terá que pagá-lo desde o afastamento, até a alta do empregado. Em contrapartida, o empregado terá direito ao recebimento do abono anual pela previdência social...

Observe-se que o empregador é responsável pelo pagamento do $13^{\circ}$ salário até $015^{\circ}$ dia de afastamento do empregado. ${ }^{155}$
\end{abstract}

Novamente, o período em que o empregador abona as faltas (os 30 primeiros dias - art. $60, \S^{\circ}$, da Lei 8.213/91 na redação da MP 664/2014) não há prestação da previdência social (artigo 476 da CLT) e, portanto, as faltas não são descontadas da gratificação natalina (artigo $2^{\circ}$ da Lei 4.090/62).

$\mathrm{Na}$ hipótese de incapacidade afastamento em razão de acidente do trabalho, o TST pacificou entendimento sobre o tema. Diz o verbete de Súmula $n^{\circ}$ 46:

46 - Acidente de trabalho (RA 41/1973, DJ 14.06.1973)

As faltas ou ausências decorrentes de acidente do trabalho não são consideradas para os efeitos de duração de férias e cálculo da gratificação natalina.

Edilberto Quintela Vieira Lins ensina que a razão dessa súmula decorria do Decreto-lei $n^{0} 7.036 / 44$, em razão das diárias pagas durante 0 primeiro ano do acidente e que não se "afinava com a Lei n 5.316 , de 1967" que integrou o afastamento em decorrência do acidente trabalho na Previdência Social ${ }^{156}$.

\footnotetext{
${ }^{154}$ Art. 40. É devido abono anual ao segurado e ao dependente da Previdência Social que, durante o ano, recebeu auxílio-doença, auxílio-acidente ou aposentadoria, pensão por morte ou auxílioreclusão.

Parágrafo único. O abono anual será calculado, no que couber, da mesma forma que a Gratificação de Natal dos trabalhadores, tendo por base o valor da renda mensal do benefício do mês de dezembro de cada ano.

${ }^{155}$ MUSSI, op. cit., 2007, p. 272/273.

${ }^{156}$ LINS, op. cit., 1984, p. 71.
} 
No sistema jurídico da época, as faltas decorrentes de acidente, pagas como diárias, realmente não poderiam ser descontadas para o cálculo da gratificação natalina. A inserção desse benefício na Previdência Social, como auxílio-doença previdenciário, não é mais tratado no contrato de trabalho como falta indenizada, eis que se trata de licença sem remuneração (artigo 476 da CLT e artigo 63 da Lei 8.213/91).

A incidência da referida Súmula $n^{\circ} 46$ deve limitar-se, portanto, ao período em que a empresa abona as faltas do empregado (primeiros trinta dias), conforme artigo $60, \S 4^{\circ}$, da Lei 8.213/91.

Finalmente, apenas para recordar, o artigo $4^{\circ}$, parágrafo único, da CLT prevê a integração do tempo de serviço para efeito de indenização e estabilidade, temas completamente diversos da gratificação natalina.

Não há como deixar de registrar entendimento contrário e majoritário, fundado no artigo $2^{\circ}$ da Lei 4090/62 e Súmula 46 do TST, no sentido de que cabe ao empregador o pagamento da gratificação natalina do empregado acidentado nesse período:

Ao dar tratamento diferenciado ao afastamento por motivo de acidente do trabalho, a lei revela seu caráter tuitivo. E a proteção ao acidentado não se restringe à visão isolada do disposto no artigo $4^{\circ}$, parágrafo único, da CLT, mas ao conjunto de normas interdependentes que, direta ou indiretamente, cuidam da matéria. ${ }^{157}$

Finalmente, há entendimento de que o pagamento da gratificação natalina estaria limitado à diferença do abono anual recebido pelo segurado da Previdência Social:

A empresa estará obrigada a remunerar a Gratificação de Natal correspondente ao período trabalhado e também aos primeiros quinze dias de afastamento. A Previdência Social, por sua vez, obriga-se ao pagamento do Abono Anual correspondente ao período de afastamento (a contar do $16^{\circ}$ dia de atestado médico), mas como o valor percebido a este título pode não corresponder ao montante

${ }^{157}$ ALLY, op. cit., 2002, p. 103. 
que o empregado receberia, se tivesse trabalhado todo o período, cabe ao empregador proceder o cálculo comparativo, efetuando-lhe o pagamento de eventual diferença. ${ }^{158}$

Com a devida venia, esse entendimento traduz verdadeira "conta de chegada", realizando dedução de direito trabalhista (gratificação natalina) por benefício previdenciário (abono anual), institutos fundados em relações jurídicas autônomas e de custeios independentes, o que nos parece uma solução nada adequada.

\subsubsection{Fundo de Garantia do Tempo de Serviço - FGTS}

O Fundo de Garantia do Tempo de Serviço - FGTS, regulado pela Lei $8.036 / 90$, é formado mediante o depósito mensal de $8 \%$ calculados sobre a remuneração paga ou devida no mês (artigo 15).

Inexistindo remuneração, justamente o que ocorre no período em que o empregado está em licença sem remuneração em razão do gozo do auxíliodoença comum (art. 476 da CLT e artigo 63, caput, da Lei 8.213/91), não há obrigação jurídica de depósito do FGTS.

Entretanto, no caso de auxílio-doença acidentário, o artigo $15, \S 5^{\circ}$, da Lei 8.036/90, determina o seu recolhimento:

Art. 15. Para os fins previstos nesta lei, todos os empregadores ficam obrigados a depositar, até o dia 7 (sete) de cada mês, em conta bancária vinculada, a importância correspondente a 8 (oito) por cento da remuneração paga ou devida, no mês anterior, a cada trabalhador, incluídas na remuneração as parcelas de que tratam os arts. 457 e 458 da CLT e a gratificação de Natal a que se refere a Lei $n^{\circ}$ 4.090, de 13 de julho de 1962, com as modificações da Lei $n^{\circ} 4.749$, de 12 de agosto de 1965.

...

§5o 0 depósito de que trata o caput deste artigo é obrigatório nos casos de afastamento para prestação do serviço militar obrigatório e licença por acidente do trabalho. (Incluído pela Lei nº 9.711, de 1998)

${ }^{158}$ VIANNA, Cláudia Salles Vilela, op cit., 2010, p. 96. 
Esse dispositivo legal concernente ao acidente de trabalho se coaduna com a proteção clássica do tempo de serviço para efeitos de indenização prevista no artigo $4^{\circ}$, parágrafo único, da CLT.

Nos primeiros trinta dias em que a empresa remunera o empregado, o artigo 28, II, do Decreto 99.684/90, determina a realização de depósitos do FGTS. Em que pese existência de posições em contrário ${ }^{159160}$, entendemos que o artigo $60, \S 3^{\circ}$, da Lei 8.213/91 é claro no sentido de que compete à empresa pagar o salário integral do empregado e que o parágrafo $\S 4^{\circ}$ apenas trata esse período como "abono das faltas" e, portanto, o pagamento estaria na incidência do artigo 15 da Lei 8.036/90 161 .

Quanto ao empregado doméstico, insta esclarecer que o regime do FGTS era facultativo até a Emenda Constitucional $n^{\circ} 72 / 2013$, de 2 de abril de 2013 e, a partir desse diploma constitucional, passou a ser obrigatório, pendente de lei regulamentar ${ }^{162}$.

\subsubsection{Aviso prévio}

O aviso prévio é regulado nos artigos 487 e seguintes da CLT, além da proporcionalidade estabelecida na Lei $\mathrm{n}^{\circ}$ 12.506/11.

\footnotetext{
${ }_{159}$ Compreende-se que esse pagamento a cargo da empresa é benefício e não salário, em razão da ausência de prestação de serviços no respectivo período, havendo ilegalidade na disposição do referido Decreto Regulamentar. Nesse sentido,vide VIANNA, Cláudia Salles Vilela, op. cit., 2010, p. 47.

${ }^{160}$ O Superior Tribunal de Justiça pacificou entendimento de natureza indenizatória desse pagamento para efeitos de contribuição previdenciária, conforme REsp 1.230.957/RS, processado e julgado sob o rito do art. 543-C do CPC.

${ }^{161}$ Nesse sentido, entendendo irrelevante a natureza do pagamento para efeitos do FGTS: STJ, $2^{\text {a }}$ Turma, Resp 1448294/RS, Dje 15/12/2014.

${ }^{162} \mathrm{Em}$ que pese prevalecer entendimento de que somente após a edição de lei stricto sensu a norma Constitucional passará a ter eficácia plena, entendo que a facultatividade de depósitos prevista na Lei 8.036/90 apenas passou a ser obrigatória; ademais, após a disponibilização do eSocial (www.esocial.gov.br) em ação conjunta da Caixa Econômica Federal, INSS, MPS, MTE e RFB, para realização dos depósitos do FGTS pelo empregador doméstico, não há razão para não se realizar a aplicação imediata desse direito social constitucionalmente previsto. Destarte, as condições para depósitos do FGTS são equivalentes a dos empregados celetistas, apenas observando-se que os primeiros 30 (trinta) dias do afastamento não são pagos pelo empregador doméstico, mas pela Previdência Social desde o primeiro dia, como acima analisado.
} 
A suspensão do contrato de trabalho (total ou parcial), como anteriormente abordada, tem a finalidade precípua da continuidade do contrato de trabalho quando o empregado fica impossibilitado de prestar a sua obrigação de fazer. Por essa razão, o aviso prévio não poderá ser efetivado durante esse período, sob pena de nulidade do ato (artigo $9^{\circ}$ da CLT).

Durante o período da suspensão, o empregado não pode ser despedido. Inválido será, por conseguinte, o aviso prévio que porventura the dê o empregador. Nada impede, porém, que, de comum acordo, dissolvam o contrato. ${ }^{163}$

Marly A .Cardone, com fulcro no artigo 187 do Código Civil, esclarece que:

Ainda que a comunicação de aviso prévio indique que a contagem de seu prazo será feita após o retorno do empregado, há abuso de direito por parte do empregador, passível de gerar pedido de indenização. ${ }^{164}$

Diferentemente, pode ocorrer a superveniência da incapacidade laborativa no curso do aviso prévio, ou seja, pré-avisado da dispensa porvir, o empregado se torna incapacitado para o trabalho por motivo de doença.

Há entendimento de que a contagem do prazo do aviso prévio seria suspensa e, após o retorno ao trabalho, novamente retomada, eis que a finalidade do aviso prévio é a busca por novo emprego que estaria prejudicada em razão do período convalescente do empregado ${ }^{165}$.

Assim, há a considerar-se o momento de a duração do evento incapacitante. Se este surge e desaparece nos limites do período do aviso, não ultrapassando o seu termo, o se prazo é prorrogado pelo tempo correspondente ao da incapacidade.

...

Contudo, é de se ponderar que, cabendo ao empregador pagar o salário de todo o período de espera, mesmo que este ultrapasse o prazo do aviso, é mais correto, sem dúvida, entrando o empregado no

\footnotetext{
${ }_{163}$ GOMES; GOTTSCHALK, op. cit., 1997, p. 465.

${ }^{164}$ CARDONE, op. cit., 2011, p. 105.

${ }^{165}$ Nesse sentido: Guillermo Cabanellas, Krotoschin, Rafael Caldera, L. Riva Sanseverino, Giuliano Mazzoni, Mattia Persiani e Vincenzo Licata. No Brasil: Hirosê Pimpão, Orlando Gomes, Octávio Bueno Magano. apud LINS, op. cit., 1984, p. 24 e 25.
} 
gozo do auxílio-doença, considerar-se como final do contrato a data do término do referido período. ${ }^{166}$

Além da finalidade do instituto, soma-se ainda o argumento de que o cumprimento do aviso-prévio (artigo 488 da CLT) pressupõe a prestação de serviço pelo empregado (obstada pela incapacidade) e de que é assegurado ao empregado todas as vantagens ${ }^{167}$ de sua categoria no seu retorno (art. 471 da $\mathrm{CLT}$ ), direitos que restariam frustrados com a continuidade da contagem do prazo do aviso prévio durante a suspensão contratual.

Nesse sentido, os precedentes que ensejaram a Súmula 371 do Tribunal Superior do Trabalho, que passou a ter a seguinte redação ${ }^{168}$ :

371 - Aviso prévio indenizado. Efeitos. Superveniência de auxíliodoença no curso deste. (Conversão das Orientações Jurisprudenciais nos 40 e 135 da SDI-1 - Res. 129/2005, DJ 20.04.2005)

A projeção do contrato de trabalho para o futuro, pela concessão do aviso prévio indenizado, tem efeitos limitados às vantagens econômicas obtidas no período de pré-aviso, ou seja, salários, reflexos e verbas rescisórias. No caso de concessão de auxíliodoença no curso do aviso prévio, todavia, só se concretizam os efeitos da dispensa depois de expirado o benefício previdenciário. (ex-OJs nos 40 e 135 - Inseridas respectivamente em 28.11.1995 e 27.11.1998)

CONCESSÃO DE AUXÍLIO-DOENÇA NO CURSO DO AVISO PRÉVIO INDENIZADO. PROJEÇÃO DOS EFEITOS DA DISPENSA PARA O TÉRMINO DO PERÍODO DE SUSPENSÃO CONTRATUAL. Nos termos da parte final da Súmula/TST $n^{\circ} 371$, a concessão de auxílio-doença no curso do aviso prévio não tem o condão de tornar nula a respectiva dispensa, mas apenas de projetar os seus efeitos para o término do período de suspensão contratual. Recurso de embargos conhecido e provido. (E-ED-RR - 17124033.2006.5.01.0054, Relator Ministro: Renato de Lacerda Paiva, Data de Julgamento: 16/05/2013, Subseção I Especializada em Dissídios Individuais, Data de Publicação: DEJT 31/05/2013)

\footnotetext{
166 Ibidem, p. 24 e 25.

${ }^{167}$ O início da Súmula 371 do TST esclarece que são as vantagens econômicas obtidas no curso do pré-aviso.

${ }^{168}$ Não se pode deixar de registrar a imensa confusão causada pela má redação da parte final da referida súmula. Há jurisprudência no TST de que o prazo do aviso-prévio não sofre qualquer suspensão do prazo e somente a extinção contratual se concretiza após a cessação do benefício previdenciário, como sugere a literalidade da referida Súmula. Nesse sentido: AIRR - 9690053.2003.5.01.0045 , Relator Desembargador Convocado: João Pedro Silvestrin, Data de Julgamento: 18/06/2014, 8 a Turma, Data de Publicação: DEJT 01/07/2014.
} 
Estamos a defender que, na hipótese, ocorre apenas a suspensão da obrigação de fazer concernente a prestar serviços. Não há motivo, portanto, de suspensão do prazo de contagem do aviso prévio.

Aguarda-se apenas a cessação da incapacidade laborativa e, por conseguinte, da suspensão contratual, para a concretização dos efeitos da dispensa. Concorda-se, pois, à jurisprudência pacificada no referido verbete sumular.

O mesmo efeito ocorre durante o período do salário-enfermidade (abono de faltas dos primeiros 30 dias após MP 664/2014), de responsabilidade do empregador, cuja extinção contratual se concretiza seus efeitos após o restabelecimento do empregado ${ }^{169}$.

Hirosê Pimpão ainda traz exceção pertinente quando o aviso-prévio parte do empregado o qual, posteriormente, torna-se incapacitado para o trabalho: "findo o prazo do aviso o contrato estará efetiva e definitivamente rompido. A doença não interrompe, pois, nesse caso, o transcurso do prazo da prévia notícia rescisória". ${ }^{170}$

Com efeito, não havendo a finalidade de período para busca de novo emprego e pelo fato de o cumprimento do aviso prévio favorecer o empregador, nada impede que a extinção contratual se concretize ao término do período, ainda porque não viola a finalidade de estabilidade da suspensão contratual.

\subsubsection{Vantagens da categoria e direitos do contrato de trabalho}

A propósito, o referido artigo 471 da CLT estabelece que:

Art. 471 - Ao empregado afastado do emprego, são asseguradas, por ocasião de sua volta, todas as vantagens que, em sua ausência, tenham sido atribuídas à categoria a que pertencia na empresa.

${ }^{169}$ Nesse sentido: Octavio Bueno Magano, apud VIANNA, Cláudia Salles Vilela. op.cit., 2010, p. 98.

${ }^{170}$ PIMPÃO, Hirosê. O aviso prévio no Direito do Trabalho. 2. ed. Rio de Janeiro: José Doinfino Editor, 1958, p. 127. 
O aspecto relevante destacado pela doutrina é que a norma estabelece a garantia de todas as vantagens atribuídas em caráter geral, não aquelas de caráter pessoal: "O empregado, ao regressar, não pode pretender auferir os mesmos proventos de seu antigo companheiro que tenha progredido, graças aos seus esforços, durante o afastamento."171

Esse dispositivo normativo também assegura, por via indireta, a impossibilidade de extinção contratual durante a suspensão do contrato de trabalho, porquanto somente poderá produzir efeito jurídico mediante a manutenção do contrato de trabalho, ou seja, para assegurar as vantagens na ocasião de sua volta, mister que ela ocorra.

Necessário salientar que não são os direitos conferidos à categoria profissional no retorno ao trabalho o objeto de nossa preocupação, garantidos na referida norma após o retorno ao trabalho, mas sim quais os direitos do contrato que não são afetados durante a suspensão contratual.

Retoma-se a ideia de que ocorre mera suspensão da prestação de fazer consistente em prestar serviços, por evidente caso fortuito. Não pode a parte contrária deixar de cumprir as obrigações contratuais que lhe são atinentes, porquanto o contrato de trabalho é sinalagmático como um todo e não prestação por prestação.

Dessa forma, apenas os direitos que tenham sua origem na prestação de serviço (por exemplo, vale-refeição, vale-transporte, aluguel de veículo, diárias), bem como aqueles expressamente excluídos nas normas jurídicas para os empregados afastados em razão de correspondência com a prestação de serviços (promoções em plano de carreira, participação nos lucros e resultados, entre outras), poderiam deixar de serem cumpridos pelo empregador.

$\overline{{ }^{171} \text { RUSSOMANO, op. cit., } 1977, \text { p. } 685 .}$ 
Ressalte-se que esse não é o entendimento majoritário. Prevalece o entendimento de que a suspensão contratual ocasiona, em regra, no congelamento dos efeitos do contrato de trabalho, como anteriormente explanado, garantindo-se os direitos somente quando expressamente previstos na norma coletiva durante a suspensão contratual.

Considerando-se, pois, a fundamentação legal existente sobre as utilidades (que aqui chamamos de benefícios contratuais) podemos concluir que não há qualquer norma imperativa que obrigue 0 empregador a manter o pagamento ou a concessão de todas as utilidades, quando do afastamento de seu empregado por motivo de doença ou acidente, percebendo benefício previdenciário de aposentadoria por invalidez. ${ }^{172}$

A doutrina pátria pouco menciona sobre a matéria, e a jurisprudência não mantém entendimento predominante, em que pese seja possível afirmar uma pequena tendência no sentido de que as empresas não se encontram obrigadas à manutenção dos benefícios contratuais durante o período do auxílio-doença. ${ }^{173}$

Entretanto, situação recorrente passou a frequentar a Justiça do Trabalho justamente sobre essa questão: a suspensão do plano de saúde do empregado durante a suspensão contratual.

Sob o argumento de que a suspensão contratual implicava no congelamento dos direitos do contrato de trabalho (suspensão dos efeitos do contrato de trabalho), diversos empregadores simplesmente cancelavam o plano de saúde do empregado justamente quando este estava incapacitado por doença, paradoxo inconcebível pela crueldade que encerrava.

A jurisprudência refutou tamanha insensatez e se pacificou por meio da Súmula 440 do Tribunal Superior do Trabalho:

440. Auxílio-doença acidentário. Aposentadoria por invalidez. Suspensão do contrato de trabalho. Reconhecimento do direito à manutenção de plano de saúde ou de assistência médica. (Resolução no 185/2012, DeJT 25.09.2012)

Assegura-se o direito à manutenção de plano de saúde ou de assistência médica oferecido pela empresa ao empregado, não

${ }^{172}$ VIANNA, op. cit., 2010, p. 52.

173 Ibidem, p. 94. 
obstante suspenso o contrato de trabalho em virtude de auxílio doença acidentário ou de aposentadoria por invalidez.

Em análise aos precedentes que resultaram no verbete, encontraramse os principais fundamentos:

a) ERR 156100-81.2005.5.05.0021, Ac. SDI-1, Redatora - Min. Maria de Assis Calsing DEJT 06.08.2010/J-24.06.2010: a suspensão do contrato de trabalho importa em suspensão das obrigações principais do contrato de trabalho - prestação de serviço e salário. Assim, o plano de saúde, por não depender da prestação de serviços, deve ser resguardado.

b) E-ED-RR-495400-18.2002.5.03.0900, Ac. SDI-1, Redator Min. Horácio: Raymundo de Senna Pires, DEJT 27/11/2009). O Direito não pode abdicar de seu substrato ético e o Direito do Trabalho em particular encontra-se vinculado aos princípios constitucionais da dignidade da pessoa humana como fundamento da própria República (art. $1^{\circ}$, III), da valorização do trabalho como alicerce da ordem econômica (art. 170), de uma ordem social baseada no primado do trabalho, tendo por objetivo o bem-estar e a justiça sociais (art. 193). Toda essa principiologia leva à consideração da pessoa do trabalhador, que não pode ser descartado como qualquer engrenagem inútil quando, doente ou acidentado no trabalho, vem a ser aposentado por invalidez, período em que se mantém hígido, embora hibernado, o contrato de emprego.

Embora o referido verbete sumular não mencione o empregado em gozo do auxílio-doença previdenciário (ou comum), não existe qualquer motivo para distinção jurídica às situações de auxílio-doença acidentário ou aposentadoria por invalidez.

Necessário salientar que a jurisprudência do Tribunal Superior do Trabalho fixou o entendimento de que os direitos derivados do contrato de trabalho (no caso, plano de saúde) não sofrem congelamentos ou suspensões quando não dependentes da prestação de serviços. 
Essa premissa fundamental corrobora o que estamos a defender no presente estudo: a suspensão da obrigação de fazer do empregado em razão de fortuito não implica no descumprimento das obrigações do contrato de trabalho pelo empregador. Inaplicável, pois, a regra civilista da exceção de contrato não cumprido, como anteriormente analisado.

Nos referidos precedentes, avança-se mais: ainda que a norma coletiva restrinja o período de concessão do plano de saúde, o benefício deve ser mantido pelo empregador.

Embora verdadeiro o fundamento de que não existe norma jurídica que determine o pagamento de vantagens da categoria ou benefícios contratuais durante o gozo do auxílio-doença, também é verdadeiro que não existe qualquer norma que exima o cumprimento de todas essas obrigações pelo empregador.

A única disposição legal a respeito encontra-se no artigo 476 da CLT:

Art. $476 \mathrm{Em}$ caso de seguro-doença ou auxílio-enfermidade, o empregado é considerado em licença não remunerada, durante o prazo desse benefício.

Por se tratar de norma restritiva de direito, sua interpretação também deve ser restritiva. Logo, a percepção de auxílio-doença implica em licença sem remuneração. A definição da remuneração está expressa no artigo 457 da CLT:

Art. 457 - Compreendem-se na remuneração do empregado, para todos os efeitos legais, além do salário devido e pago diretamente pelo empregador, como contraprestação do serviço, as gorjetas que receber. (Redação dada pela Lei n 1.999, de 1.10.1953)

$\S 1^{\circ}$ - Integram o salário não só a importância fixa estipulada, como também as comissões, percentagens, gratificações ajustadas, diárias para viagens e abonos pagos pelo empregador. (Redação dada pela Lei $n^{\circ} 1.999$, de 1.10.1953)

$\S 2^{\circ}$ - Não se incluem nos salários as ajudas de custo, assim como as diárias para viagem que não excedam de $50 \%$ (cinqüenta por cento) do salário percebido pelo empregado. (Redação dada pela Lei $n^{\circ}$ 1.999, de 1.10.1953)

$\S 3^{\circ}$ - Considera-se gorjeta não só a importância espontaneamente dada pelo cliente ao empregado, como também aquela que fôr cobrada pela emprêsa ao cliente, como adicional nas contas, a qualquer título, e destinada a distribuição aos empregados. (Redação dada pelo Decreto-lei $n^{\circ} 229$, de 28.2.1967) 
É certo que as demais vantagens de natureza não remuneratórias, tais quais as previstas no artigo $458, \S 2^{\circ}$, da CLT (desde que não dependam da prestação de serviço), em que se inclui o plano de saúde, bem como aquelas previstas em instrumentos normativos que não detenham natureza remuneratória (educação, auxílio-farmácia, cesta básica, entre outros), não são atingidas pelo determinado dispositivo legal.

A suspensão da obrigação de fazer de prestar serviços, por motivo fortuito, não implica na supressão dessas vantagens, porquanto derivam do contrato de trabalho e não da prestação de serviços.

Somente a remuneração (art. 476 da CLT) e aquelas vantagens ou direitos que são correlacionados à própria prestação de serviços é que poderão ser suprimidos.

A corroborar esse pensamento, pode-se ainda arguir a existência de uma similitude de situação, quando se trata de suspensão do contrato de trabalho.

A utilização da analogia decorre do ensinamento: ubi eadem ratio, ibi eadem juris dispositio (onde há a mesma razão deve haver a mesma disposição de direito).

Note-se que a analogia não se reduz a mero processo lógico-formal, inserindo-se, ao contrário, no processo axiológico ou teleológico do sistema normativo, em virtude de algo mais profundo, ligado à estrutura da experiência jurídica, e não apenas como consequência formal de semelhanças entre um caso particular e outro. ${ }^{174}$

Nesse esteio, não se pode olvidar a expressa previsão do artigo 476-A, $\S 4^{\circ}$, da CLT, que trata de suspensão contratual para qualificação profissional:

174 REALE, Miguel. Lições preliminares de direito. 24. ed. São Paulo: Saraiva, 1998, p. 299. 
$\S 4$ 으 Durante o período de suspensão contratual para participação em curso ou programa de qualificação profissional, o empregado fará jus aos benefícios voluntariamente concedidos pelo empregador. (Incluído pela Medida Provisória n².164-41, de 2001)

Essa norma imperativa cogente (não permite a negociação coletiva nesse ponto) regula situação semelhante (de suspensão contratual por fato alheio à vontade do trabalhador - negociação coletiva - embora a lei exija sua aquiescência em ato complexo para a sua validade), e alicerça-se na mesma identidade axiológica e teleológica (garantir a subsistência do trabalhador enquanto perdurar a suspensão contratual e aplicabilidade dos princípios constitucionais invocados no precedente da Súmula 440 do TST estão igualmente presentes à espécie), permite compreender que essa solução jurídica pode ser aplicada à hipótese.

A suspensão das vantagens derivadas de cláusula contratual (expressa ou tácita) também viola o artigo 468 da CLT, pois, mesmo que a supressão seja temporária, produz eficácia de alteração contratual (com o consequente inadimplemento) durante esse período:

Se, por força do princípio da conservação do emprego, quando suspenso o contrato de trabalho, não pode ser ele extinto por denúncia vazia do empregador, pela mesma razão está imune de sofrer alterações ilícitas ou prejudiciais ao empregado ${ }^{175}$.

Auxílio-doença. Suspensão do contrato de trabalho. Impossibilidade de sua alteração em prejuízo do empregado. Conforme art. 476 da CLT, o afastamento do empregado em gozo de auxílio-doença é causa de suspensão do contrato de trabalho, o qual, por isso, permanece vigente e com plena eficácia de suas cláusulas, sobretudo daquelas que não encontram óbice nesse estado de inativação forçada do trabalhador. Entre essas cláusulas cuja eficácia permanece, estão, notadamente, aquelas que impõem condutas omissivas ao empregador, como, por exemplo, a que, implicitamente, veda a realização de alterações contratuais prejudiciais ao empregado, em decorrência do disposto no artigo 468 da CLT. Assim sendo, durante esse afastamento, o empregador não poderá excluir o empregado do plano de saúde que mantinha nem poderá tornar mais dispendiosa a manutenção do benefício. TRT $3^{a}$ Região. RO 0001476-28-2010.5.03.0030, 6a Turma, DEJT 16/05/2011.

${ }^{175}$ LINS, op. cit., 1984, p. 147. 
Ainda nesse contexto, nem mesmo a norma coletiva poderia suprimir ou restringir vantagens durante a suspensão contratual, quando se originarem do contrato de trabalho e não, especificamente, da prestação de serviços.

As normas coletivas restritivas dessas vantagens, além de exorbitarem os limites da autonomia coletiva ${ }^{176}$, produzem verdadeiro caráter discriminatório em relação ao empregado incapacitado por motivo de doença, porque não fundadas na única diferença entre os empregados: a prestação de serviço ou sua ausência.

Nesse raciocínio, inexplicável o precedente a seguir colacionado, que entendeu devido o plano de saúde porque "apenas importa em suspensão das obrigações principais do contrato de trabalho - como a prestação de serviços e o pagamento de salário" e afastou o pagamento de mensalidade da reclamante diante de não existir violação ao artigo 468 da CLT, porque estaria apenas suspenso o benefício e não suprimido, e por inexistência de violação ao princípio da igualdade diante da suspensão contratual:

RECURSO DE REVISTA DA RECLAMANTE. RESTABELECIMENTO DO PLANO DE SAÚDE. AUXÍLIO-DOENÇA. A suspensão do contrato por auxílio-doença não põe fim ao contrato de trabalho, ficando o trabalhador apenas sem prestar serviço e sem receber salário. As demais cláusulas contratuais remanescem. Por essa razão, a supressão unilateral do plano de saúde, sem justificativa legal e plausível, não poderia ter ocorrido. Recurso de revista conhecido e provido..

$\ldots$

AJUDA DE CUSTO. PAGAMENTO DE MENSALIDADE DE FACULDADE DA RECLAMANTE. SUSPENSÃO DO CONTRATO DE TRABALHO. SUSPENSÃO DO PAGAMENTO DO BENEFÍCIO. A suspensão do contrato de trabalho decorrente do afastamento da reclamante e da percepção de auxílio-doença determina a suspensão do pagamento do benefício de ajuda de custo relativa às mensalidades da faculdade cursada pela autora. Inexiste, pois, violação aos arts. 444 e 468 da CLT. Recurso de revista não conhecido. ( Ementa parcial - RR - 281-68.2010.5.12.0026 , Relator

\footnotetext{
${ }^{176}$ Maurício Godinho Delgado ensina que o Princípio da Adequação Setorial Negociada exige que a validade e eficácia da norma coletiva dependem de estabelecerem normas superiores ao padrão geral das fontes heterônomas, e que a transação se limite às normas de indisponibilidade apenas relativas. Vide: DELGADO, Maurício Godinho. op. cit., 2006, p. 1320.

$\mathrm{Na}$ hipótese, entendemos que a suspensão das vantagens contratuais que derivem do contrato de trabalho e não, especificamente, da prestação de serviços, viola o Artigo 468 da CLT e cria distinção juridicamente injustificável no contrato de trabalho.
} 
Ministro: Aloysio Corrêa da Veiga, Data de Julgamento: 27/06/2012, $6^{\mathrm{a}}$ Turma, Data de Publicação: DEJT 06/07/2012)

O referido julgado é exemplo adequado para demonstrar a dificuldade em sistematização teórica dos efeitos da suspensão do contrato de trabalho. $O$ fundamento jurídico para a concessão do plano de saúde (regulado no artigo 458, $\S 2^{\circ}$, IV da CLT) caminhou em um sentido (suspensão apenas das obrigações principais do contrato de trabalho), enquanto que o pagamento de educação (regulado no artigo $458, \S 2^{\circ}$, II, da CLT) não foi assegurado, em evidente paradoxo lógico-jurídico a nosso ver.

Suspensa apenas a obrigação de fazer consistente em prestar serviços e vigentes as demais cláusulas do contrato de trabalho, não haveria motivo de tratamento diferenciado entre os direitos previstos no artigo $458, \S 2^{\circ}$, da CLT, salvo aqueles correlacionados à efetiva prestação de serviços.

\subsubsection{Extinção contratual}

Anteriormente se abordou que ideia precípua da suspensão contratual é a estabilidade do trabalhador, ou seja, impedir que ocorra a extinção contratual no período em que o contrato de trabalho esteja suspenso e que the sejam garantidas todas as vantagens da categoria quando de seu retorno ao trabalho.

Entretanto, esse impedimento não é absoluto. Em verdade, ele retira do empregador a possibilidade de dispensar o empregado sem justa causa, extirpando, nesse período, o caráter potestativo da dispensa.

Resulta também da figura suspensiva a inviabilidade de resilição unilateral do contrato por ato do empregador no período de sustação dos efeitos contratuais (art. 471, CLT). Ou seja, a dispensa obreira injusta ou desmotivada (isto é, sem os motivos considerados justos pela lei) é vedada nas situações suspensivas. ${ }^{177}$

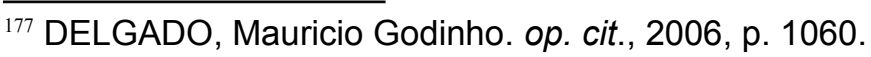


Entretanto, existem inúmeras possibilidades de extinção contratual do contrato de trabalho suspenso, identificadas pela ausência da vontade unilateral das partes, como bem analisado por Cláudia Salles Vilela Vianna ${ }^{178}$ :

... apenas as rescisões que não dependem da vontade unilateral das partes é que são susceptíveis de ocorrência, como ocorre, por exemplo, com a extinção do estabelecimento empregador, o cometimento de falta grave do artigo 482 da CLT, o falecimento do trabalhador e outras hipóteses de força maior. ${ }^{179}$

\section{Especificamente quanto à justa causa (artigo 482 da CLT) ou à}

rescisão indireta do contrato de trabalho (artigo 483 da CLT), não há qualquer norma jurídica que impeça a extinção contratual imediatamente ${ }^{180}$.

A despedida, com efeitos imediatos, pode ser praticada sempre que fundada em uma causa prevista no art. 482, e que não dependa de efetiva prestação de serviços. ${ }^{181}$

Nada impede que o ato tradutor da dispensa se efetue no decurso do benefício previdenciário, o que faz evitar a falta de imediatidade entre causa e efeito, com possíveis prejuízos para a prova do ilícito trabalhista. Existindo este, não prevalece o princípio da ineficácia da despedida no período da suspensão do contrato e não há razão de se aguardar, às vezes por longos anos, para a concretização da medida, a reapresentação do empregado ao término da licença. ${ }^{182}$

Como diversas vezes destacado anteriormente, defendemos que a suspensão da obrigação de fazer de prestar serviços não implica na suspensão automática de todas as cláusulas contratuais. Por essa razão, é evidente que as obrigações que derivem do contrato de trabalho permaneçam vigentes e que as violações às obrigações especificadas nos artigos 482 ou 483 da CLT impliquem na extinção contratual, inclusive no período de suspensão contratual.

\footnotetext{
${ }^{178}$ VIANNA, op. cit., 2010, p. 91.

179 Registre-se que o Tribunal Superior do Trabalho não admite a extinção contratual, na aposentadoria por invalidez, por fechamento de estabelecimento do empregador, quando a empresa continue ativa ou exista outra empresa do mesmo grupo: RR-38500-25.2008.5.15.0128, Relator Ministro: Renato de Lacerda Paiva, Data de Julgamento: 21/8/2013, $2^{\text {a }}$ Turma, Data de Publicação: DEJT 30/8/2013; e RR-37700-94.2008.5.15.0128, Relatora Ministra: Dora Maria da Costa, Data de Julgamento: 22/6/2011, 8 a Turma, Data de Publicação: DEJT 27/6/2011.

${ }^{180} \mathrm{Em}$ sentido contrário: FERRARI, Irany. Dispensa por justa causa no curso de benefício auxíliodoença. Efeitos. 1928-2012. LTr - Suplemento Trabalhista. São Paulo, a. 43, nº. 8, p. 32, 2007, p. 32.

${ }^{181}$ CATHARINO, José Martins. Contrato de Emprego. Salvador: Edição do Autor, 1963, p. 254.

${ }^{182}$ LINS, op. cit., 1984, p. 143.
} 
A ideia de estabilidade na qual se fundamenta a suspensão contratual não se subsiste no caso de falta grave do empregado e é inaplicável à falta grave do empregador.

Entretanto, o entendimento majoritário é diverso, quando se trata de falta grave realizada antes da suspensão contratual pelo empregado, embora não haja qualquer distinção normativa entre a falta grave ter ocorrido antes ou durante a suspensão contratual:

No tocante à dispensa por justa causa não pode haver dúvida de ser ela viável, juridicamente, desde que a falta tipificada obreira tenha ocorrido no próprio período de suspensão do pacto.

Será distinta, contudo, a solução jurídica em se tratando de justa causa cometida antes do advento do fator suspensivo... Nesse caso, a suspensão contratual prevalece, embora possa a empresa comunicar de imediato ao trabalhador a justa causa aplicada, procedendo, contudo, à efetiva rescisão após o findar da causa suspensiva do pacto empregatício. ${ }^{183}$

Nessa mesma linha, a jurisprudência majoritária do Tribunal Superior do Trabalho.

\begin{abstract}
RECURSO DE EMBARGOS. RECURSO DE REVISTA CONHECIDO E DESPROVIDO. AÇÃO DECLARATÓRIA. EMPREGADO EM GOZO DE AUXÍLIO-DOENÇA. INDICAÇÃO DE CONDUTA CAUSADORA DE DISPENSA POR JUSTA CAUSA. PERÍODO ANTERIOR À SUSPENSÃO DO CONTRATO DE TRABALHO. 1. A decisão da C. Turma entendeu não ser possível dispensa por justa causa de empregado que esteja usufruindo benefício de auxílio-doença perante a previdência social, porque o contrato de trabalho está suspenso, ainda que o motivo da dispensa seja anterior à licença. 2. Há norma legal prevendo a suspensão do contrato de trabalho durante o curso do afastamento para percepção de benefício previdenciário (art. 471 da CLT), o que impede a rescisão do contrato de trabalho no período. Desse modo, correta a decisão da C. Turma que manteve o entendimento da eg. Corte a quo que inviabilizou o acolhimento de ação declaratória visando a extinção do contrato de trabalho, ainda que a conduta tida como motivadora de dispensa tenha ocorrido antes da suspensão do contrato de trabalho. Embargos conhecidos e desprovidos.

(E-RR-6580600-58.2002.5.04.0900 Data de Julgamento: 10/6/2010, Relator: Ministro Aloysio Corrêa da Veiga, Subseção I Especializada em Dissídios Individuais, Data de Publicação: DEJT 18/6/2010.)
\end{abstract}

${ }^{183}$ DELGADO, Maurício Godinho. op. cit., 2006, p. 1061. 
RECURSO DE REVISTA. RESCISÃO CONTRATUAL. DISPENSA POR JUSTA CAUSA. EMPREGADO EM GOZO DE BENEFÍCIO PREVIDENCIÁRIO. CONTRATO DE TRABALHO SUSPENSO. Delimita-se a controvérsia em saber se é válida a rescisão do contrato de trabalho, por justa causa, enquanto pendente fator suspensivo, consubstanciado pelo afastamento previdenciário do empregado por período superior a 15 dias. Compreende-se que, se a falta grave imputada ao obreiro for anterior ao seu licenciamento, mas apurada somente quando suspenso o contrato, o ato demissório, embora não seja, por esse motivo, inválido, somente virá a produzir efeitos após o término do fator suspensivo, no caso, após a convalescença do empregado. Precedentes. Recurso de revista conhecido e parcialmente provido.

(Processo: RR- 160900-87.2006.5.05.0581, Relatora: Ministra Delaíde Miranda Arantes, $7 .^{a}$ Turma, Data de Publicação: DEJT 17/8/2012.)

Da mesma forma, não há qualquer vedação ao pedido de demissão realizado pelo empregado no curso da suspensão contratual. Ocorre que, nessa situação, poderia se caracterizar renúncia ao direito de retorno ao trabalho por parte do empregado. Necessário, pois, a verificação das circunstâncias em que isso ocorreu a fim de que o ato seja válido:

\begin{abstract}
Pode-se afirmar, também, que, em princípio, terá validade pedido de demissão obreiro que se concretize no curso de fator suspensivo do contrato. A negativa de validade a tal pedido de demissão independentemente dos sujeitos, circunstâncias e fatores suspensivos envolvidos - implicaria eliminação injustificada de uma liberdade essencial do ser humano. Entretanto, em tal caso, o operador jurídico deverá examinar, cuidadosamente, os sujeitos, fatores e circunstâncias envolvidos, aferindo se houve (ou não) burla às finalidades protetivas perseguidas pelo Direito do Trabalho... parece prudente considerar-se aplicável à presente situação a formalidade rescisória prevista pelo art. 500 da CLT (abrangente do empregado estável): ou seja, pedido de demissão com assistência sindical ou administrativa ou de jurisdição voluntária ${ }^{184}$.
\end{abstract}

Da mesma forma, mesmo estando afastado, o empregado sempre tem o direito de pedir demissão. Diante do princípio constitucional da liberdade de trabalho (artigo $5^{\circ}$, XIII, da Lei Maior) pode o trabalhador preferir não mais se ativar em face de seu empregador, desde que se observe a higidez desta manifestação de vontade. ${ }^{185}$

\footnotetext{
${ }^{184}$ Ibidem, p. 1062.

185 GARCIA, Gustavo Filipe Barbosa. Suspensão do contrato de trabalho e dispensa do empregado. São Paulo: Repertório de Jurisprudência IOB. vol. 2, nº. 9, p. 258, $1^{a}$. quinz. Maio/2005, p. 257.
} 
Não se pode olvidar que o Tribunal Superior do Trabalho entende necessária a assistência sindical para qualquer pedido de demissão no contrato de trabalho superior a um ano (artigo $477, \S 1^{\circ}$, da CLT):

EMBARGOS. PEDIDO DE DEMISSÃO NÃO HOMOLOGADO PERANTE SINDICATO. RECURSO DE REVISTA NÃO CONHECIDO O objetivo da assistência sindical no pedido de demissão decorre da consagração ao princípio da irrenunciabilidade dos direitos trabalhistas. Retrata o art. 477, $\S 1^{\circ}$, da CLT, norma cogente, que condiciona o pedido de demissão e a quitação do contrato de trabalho firmado pelo empregado cuja relação jurídica vigeu por mais de um ano, à homologação perante o Sindicato. Nesse sentido, a formalidade determinada pela norma, se não cumprida, torna nulo o ato. A prova de ausência de coação, quando ausente homologação, não pode ser imputada ao empregado. Incumbe ao empregador, o cumprimento da formalidade prevista no art. $477, \S 1^{\circ}$, da CLT, sob pena de não se convalidar o pedido de demissão, quando não houver a homologação, nos termos previstos na norma. Precedente da c. SDI. Embargos conhecidos e providos. (E-ED-RR - 6622.2011.5.05.0004, Relator Ministro: Aloysio Corrêa da Veiga, Data de Julgamento: 20/06/2013, Subseção I Especializada em Dissídios Individuais, Data de Publicação: DEJT 01/07/2013).

Ainda por essas razões, entende-se definitivamente necessária a assistência sindical como requisito de validade do ato.

Há de se considerar, finalmente, a possibilidade de extinção contratual por comum acordo das partes. A figura do distrato, em razão do princípio protetivo do Direito do Trabalho, assume características de dispensa sem justa causa $^{186}$.

Na suspensão contratual, embora vedada a dispensa sem justa causa, nada impede que as partes negociem a extinção contratual por comum acordo ${ }^{187}$.

Durante o período da suspensão, o empregado não pode ser despedido. Inválido será, por conseguinte, o aviso prévio que porventura the dê o empregador. Nada impede, porém, que, de comum acordo, dissolvam o contrato. ${ }^{188}$

\footnotetext{
${ }^{186}$ Ibidem. p. 1131.

${ }^{187}$ Em sentido contrário Messias Donato defende que: "é passível de anulação a resilição do contrato com base em acordo dos co-contratantes". Apud LINS, op. cit., 1984, p. 140.

${ }^{188}$ GOMES; GOTTSCHALK, op. cit., 1997, p. 465.
} 
Novamente, recorde-se a cautela redobrada que a matéria exige quanto à impossibilidade de renúncia de direito, a necessidade de assistência sindical ou jurisdição voluntária (procedimento análogo ao artigo 500 da CLT).

Sobre esse ponto, necessário registrar o posicionamento de Edilberto Quintela Vieira Lins ${ }^{189}$, da validade do distrato e desnecessidade do procedimento do artigo 500 da CLT:

\begin{abstract}
Portanto, afora os casos de incapacidade ou de eiva na manifestação da vontade de um dos contratantes, o distrato do pacto laboral suspenso é perfeitamente válido. Com efeito, já foi decidido que "lícita é a transação relativa aos direitos decorrentes do contrato de trabalho, ainda que suspenso em razão do gozo de benefício previdenciário, desde que homologado judicialmente"190, embora a ressalva esteja a merecer reparo. Mesmo para o empregado com estabilidade efetiva não é exigido o requisito. A lei requer, apenas, a assistência dos órgãos indicados no art. 500 da CLT.
\end{abstract}

Momento oportuno para esclarecer situações de verdadeiro distrato que se apresentam no cotidiano da Justiça do Trabalho. O empregado comparece perante o juízo e declara sua vontade de rescisão contratual durante o curso da suspensão contratual por motivo de doença.

Os motivos podem ser diversos, sendo mais comuns: a alta médica (programada) somente ocorrerá depois de mudar para outro Estado da Federação, quando não mais retornará para os trâmites da rescisão contratual ou colher documentos para o requerimento do auxílio-doença (a informação da data do último dia trabalhado pelo empregador é condição para requerimento do benefício); não ter mais qualquer interesse em retornar ao trabalho referente ao contrato suspenso.

Essas situações implicam em conciliação judicial com a respectiva pacificação social acobertada pelo manto da coisa julgada. Caberá ao juízo homologador do acordo a verificação das condições (concessões recíprocas) em que ele se estabeleceu (inexistência de qualquer vício de consentimento ou

\footnotetext{
${ }^{189}$ LINS, op. cit., 1984, p. 140.

${ }^{190}$ TRT 4ª. Região. Processo 2.145/78, apud LINS, op. cit., 1984, p. 140.
} 
renúncia a direitos incontroversos) para o fim de lhe atribuir os efeitos jurídicos pertinentes.

Homologada a conciliação avençada, como dizer que extinção contratual, por distrato ou convenção das partes, durante a suspensão contratual, não é válida? Por inexistir qualquer vedação legal a esse desiderato, a validade e eficácia da extinção contratual permanecerão intactas. Finalmente, em razão de a conciliação ser requerida por ambas as partes, sequer haverá nova discussão judicial a respeito.

Finalmente, cabe-se recordar que não é qualquer incapacidade laborativa que impede a extinção contratual. Como anteriormente exposto, a incapacidade pode ser total ou parcial (Capítulo 3).

A suspensão contratual ocorre diante da incapacidade total para determinada atividade (artigo 59 da Lei 8.213/91 e, após a MP 664/2014, artigo 60 , caput, da Lei 8.213/91), enquanto o empregado não for reabilitado para o exercício profissional de outra atividade (artigo 62 da Lei 8.213/91).

A incapacidade parcial (quando derivada de acidente do trabalho) implica no recebimento do auxílio-acidente (artigo 86 da Lei 8.213/91), mas não implica na suspensão do contrato de trabalho.

Entretanto, há entendimento no sentido de que a mera incapacidade parcial obsta a extinção contratual, que somente poderá ser realizada após o restabelecimento integral do trabalhador:

AGRAVO DE INSTRUMENTO EM RECURSO DE REVISTA EM FACE DA DECISÃO PUBLICADA ANTES DA VIGÊNCIA DA LEI N ${ }^{\circ}$ 13.015/2014. 1. NEGATIVA DE PRESTAÇÃO JURISDICIONAL. A decisão não foi contraditória nem omissa, pois contém elementos suficientes à demonstração da efetiva e completa apreciação das matérias postas. Com efeito, reconheceu a incapacidade parcial para o trabalho e considerou que o fato de o INSS não ter concedido o benefício do auxílio-doença não impede o reconhecimento da estabilidade provisória decorrente de doença ocupacional. Não 
configurada, portanto, negativa de prestação jurisdicional. 2. REINTEGRAÇÃO DECORRENTE DE ESTABILIDADE ACIDENTÁRIA. Infere-se do acórdão que a reclamante não poderia ser dispensada, tendo em vista que desde antes da dispensa, em virtude de incontroversa doença ocupacional, teve reduzida a sua capacidade laboral, razão por que o Regional manteve a reintegração deferida na sentença, pois só poderia ser dispensada após o completo restabelecimento para o trabalho. 3. QUANTUM INDENIZATÓRIO DO DANO MORAL. Somente se admite o processamento do recurso de revista para fins de reexame do quantum indenizatório do dano moral quando a parte aponta expressa e fundamentadamente, violação ao art. 944 do $C C$, não sendo esta a hipótese. Agravo de instrumento desprovido.

(AIRR - 71900-36.2009.5.02.0361 , Relator Desembargador Convocado: Arnaldo Boson Paes, Data de Julgamento: 10/12/2014, $7^{\text {a }}$ Turma, Data de Publicação: DEJT 12/12/2014)

A situação fática da jurisprudência colacionada se referia à redução da capacidade do membro superior direito, o que implicou na reintegração do empregado até doze meses após seu integral restabelecimento. Sob essa óptica, o empregado poderá obter uma estabilidade indefinida.

O mesmo ocorreria em diversas situações, por exemplo, em relação à perda auditiva parcial (doença ocupacional) e em relação ao empregado (acidente típico) que tivesse uma falange do dedo mínimo amputado, porquanto não se restabeleceriam integralmente.

Esse entendimento (seguido por tantos outros) não corresponde à sistemática normativa da incapacidade laborativa, como anteriormente explanado.

Não se olvide que a garantia de emprego não se confunde com a indenização por acidente de trabalho (artigo 950 do Código Civil), essa de possível caráter vitalício por redução da capacidade laborativa.

\subsubsection{Peculiaridades dos contratos a termo}

Os contratos a termo são exceção à regra geral do Direito do Trabalho, porquanto somente podem ser validamente pactuados diante de expressa previsão legal (por exemplo: artigo $443, \S 2^{\circ}$, da CLT). 
A extinção do contrato de trabalho a termo no curso de sua suspensão é revestida de peculiaridade potencializada por entendimentos jurídicos diferentes: a) o prazo da suspensão contratual não altera o curso do contrato a termo; b) o contrato a termo apenas se extingue no dia seguinte a que se findar a suspensão contratual; e c) o prazo do contrato a termo se suspende, remanescendo pelo período restante após a cessação da suspensão contratual.

O primeiro entendimento deriva da aplicação do artigo $472, \S^{\circ}$, da CLT:

Art. 472 - $O$ afastamento do empregado em virtude das exigências do serviço militar, ou de outro encargo público, não constituirá motivo para alteração ou rescisão do contrato de trabalho por parte do empregador.

...

$\S 2^{\circ}$ - Nos contratos por prazo determinado, o tempo de afastamento, se assim acordarem as partes interessadas, não será computado na contagem do prazo para a respectiva terminação.

$\mathrm{Na}$ forma desse entendimento, o dispositivo legal se aplicaria a qualquer contrato por prazo determinado, não somente nos afastamentos do serviço militar ou de outro encargo público:

O objetivo escancarado foi prestigiar os contratos provisórios e temporários, que não poderiam ser elastecidos por intercorrências alheias à vontade das partes.

Não há suspensão de contagem de prazo, embora possa haver suspensão de trabalho e de salário. Ressalva-se o direito das partes de ajustarem em sentido contrário, ou seja, é válida a cláusula contratual de congelamento da contagem do prazo do contrato de trabalho determinado, em caso de suspensão da prestação dos serviços, mas isso se torna raríssimo de ver e de acontecer...

Do ponto de vista da hermenêutica, aqui se fez uma analogia ao expandir para casos semelhantes o preceito de lei que melhor trata da matéria, explicação que se prefere àquela que atribui vida autônoma ao $\S 2^{\circ}$, desconectado do caput. ${ }^{191}$

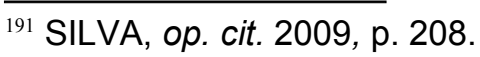


Finalmente, no contexto do que defendemos de que há apenas a suspensão da prestação de fazer concernente à prestação de serviço e não da vigência das cláusulas contratuais automaticamente, não há qualquer norma jurídica atinente à incapacidade laborativa por motivo de doença que determine a suspensão do prazo do contrato a termo, sendo certo que a ideia de estabilidade da suspensão contratual não suplantaria o termo fixado pelas próprias partes. Outrossim, não parece razoável a possibilidade de prolongamento do contrato por período de diversos dias, meses ou anos, caso a suspensão contratual perdure por esse período.

Nesse sentido, colacionam-se os seguintes julgados:

CONTRATO DE EXPERIÊNCIA - PERCEPÇÃO DE AUXÍLIODOENÇA - CONTAGEM DO PRAZO PARA A SUA TERMINAÇÃO $O$ afastamento do empregado por motivo de doença, com recebimento de auxílio-doença previdenciário, via de regra, suspende o contrato de trabalho. Todavia, tal não sucede nos contratos por prazo determinado, gênero no qual se inclui o contrato de experiência, visto que nestes pactos o tempo de afastamento é computado na contagem do prazo para a sua respectiva terminação, somente ocorrendo de modo distinto se houver expressa convenção das partes a respeito (art. $472, \S 2^{\circ}$, da CLT).

(TRT 12a R. - RO 00101.2005.033.12.00.9 - 3a T. - Rel ${ }^{a}$ Juíza Tereza Regina Cotosky - DJSC 14.12.2005)

RECURSO DE REVISTA - CONTRATO DE EXPERIÊNCIA GARANTIA DE EMPREGO ACIDENTÁRIA - I- O Tribunal Regional negou provimento ao recurso ordinário interposto pelo Reclamante e manteve a sentença, em que se rejeitou o pedido de reconhecimento do direito à garantia de emprego acidentário. Consignou que as partes celebraram contrato de experiência com vigência de 45 dias. Entendeu que a superveniência de acidente de trabalho típico não justifica "a transformação desse tipo de contrato a termo certo em contrato por prazo indeterminado". Considerou que, nos casos de acidente de trabalho, ocorre "uma suspensão do contrato de trabalho que não tem o condão de prorrogar o termo do contrato por prazo determinado, salvo previsão contratual expressa, observando-se, analogamente, o disposto no parágrafo $2^{\circ}$ do art. 472 da CLT". (Ementa parcial - TST - RR 2031/2007-010-15-00.5 - Rel. Min. Fernando Eizo Ono - DJe 03.06.2011)

O segundo entendimento deriva da interpretação sistemática do artigo

471 e $472, \S 2^{\circ}$, da CLT: 
O que justificaria tal variante seria a leitura combinada dos preceitos dos artigos $472, \S 2^{\circ}$ e 471 da CLT, hábil a preservar a modalidade determinada do contrato de trabalho sem o traumatismo de sua extinção em pleno curso de um fator suspensivo ou interruptivo valorizado pela ordem jurídica. ${ }^{192}$

Nesse sentido, colaciona-se a seguinte jurisprudência do Tribunal Superior do Trabalho, que se coaduna com o entendimento da Súmula 371 :

RECURSO DE REVISTA. CONTRATO DE EXPERIÊNCIA. AUXÍLIODOENÇA COMUM. EFEITO. Se, no curso do contrato de trabalho, houver percepção de auxílio-doença previdenciário, o efeito produzido é a suspensão do pacto laboral. No contrato de experiência, contudo, a exclusão do referido período da duração do contrato somente é computada quando houver sido expressamente convencionado pelas partes. Inteligência do artigo $472, \S 2^{\circ}$, da CLT. No entanto, embora não seja o caso de transmudação em contrato por prazo indeterminado, como entendeu a Corte de origem, os efeitos do término do contrato de experiência somente se concretizarão após a alta médica, quando e se houver. Incidência, por analogia, da parte final da Súmula $n^{\circ} 371$ deste Tribunal Superior. Recurso de revista de que se conhece e a que se dá provimento parcial. ( RR - 225819.2010.5.12.0019, Relator Ministro: Cláudio Mascarenhas Brandão, Data de Julgamento: 25/03/2014, $7^{a}$ Turma, Data de Publicação: DEJT 28/03/2014)

AUXÍLIO-DOENÇA NO CURSO DE CONTRATO DE EXPERIÊNCIA - SUSPENSÃO. A percepção de auxílio-doença no curso de contrato de experiência, espécie de contrato por prazo determinado, acarreta sua suspensão, conforme previsto no art. 476 da CLT. Não ocorre, contudo, prorrogação. Assim, a data de extinção do contrato de trabalho dá-se no momento da expiração do benefício previdenciário. São devidos ao Reclamante somente saldo salarial, décimo terceiro proporcional, férias proporcionais e respectivo adicional e depósitos do FGTS, até o início da percepção do benefício previdenciário, autorizada a compensação. Recurso conhecido e parcialmente provido. Invertido o ônus da sucumbência, com isenção do recolhimento das custas.

(RR - 1432600-55.2002.5.02.0902, Relatora Ministra: Maria Cristina Irigoyen Peduzzi, Data de Julgamento: 30/06/2004, $3^{\text {a }}$ Turma, Data de Publicação: DJ 20/08/2004)

Finalmente, há jurisprudência do Tribunal Superior do Trabalho que entende a existência de suspensão da contagem do prazo do contrato a termo, o qual teria o seu prazo prorrogado ao final:

Agravo de instrumento. RECURSO DE REVISTA. DIVERGÊNCIA JURISPRUDENCIAL. Ao contrário do entendimento do r. despacho agravado, restou demonstrada divergência jurisprudencial

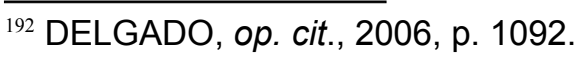


autorizadora do processamento do Recurso de Revista. Agravo de Instrumento provido. recurso de revista. CONTRATO DE EXPERIÊNCIA. ACIDENTE DE TRABALHO. SUSPENSÃO. PRORROGAÇÃO DO PRAZO. O contrato de experiência é modalidade de contrato por prazo determinado (artigo 443, § $2^{\circ}$, "c", da CLT), e, sendo com termo certo, a transitoriedade da respectiva prestação de serviços extingue-se naturalmente pelo decurso do prazo. Entretanto, a concessão de auxílio-doença, pela Previdência Social, suspende o contrato de trabalho, impossibilitando a rescisão contratual. Recurso de Revista conhecido e provido.

(RR - 3240-33.2006.5.04.0201, Relator Ministro: José Simpliciano Fontes de F. Fernandes, Data de Julgamento: 18/12/2007, $2^{\mathrm{a}}$ Turma, Data de Publicação: DJ 15/02/2008)

CONTRATO DE EXPERIENNCIA. ACIDENTE DE TRABALHO NO CURSO DO CONTRATO. PRORROGAÇÃO DO PRAZO. POSSIBILIDADE. 1 . Ocorre a suspensão do contrato de experiência na hipótese de afastamento do empregado por acidente de trabalho, podendo, assim, tal contrato ser retomado após a alta médica, pelo tempo faltante para completar os 90 (noventa) dias, sem que isso implique a modificação na modalidade do contrato, tornando-o indeterminado. 2. Recurso de revista conhecido e provido." (grifos acrescidos)

(RR-119200-72.2002.5.15.0071, Rel. Min. Emmanoel Pereira, $1^{\text {a }}$ Turma, DJ 10/03/2006)

RECURSO DE REVISTA. INTEMPESTIVIDADE DO RECURSO ORDINÁRIO DA RECLAMADA. Não há que se falar em intempestividade quando o recurso é interposto dentro do prazo legal; ou no lapso em que tal prazo se encontra interrompido pela oposição de embargos de declaração pela parte contrária. Tampouco há necessidade de ratificação ou oposição de novo recurso. Precedentes. Não conhecido. GESTANTE. INTERRUPÇÃO E SUSPENSÃO DO CONTRATO DE EXPERIÊNCIA. A decisão encontra-se em consonância com a iterativa e notória jurisprudência desta Corte, no sentido de que, interrompido o período de experiência pela concessão do auxílio doença, a contagem do prazo é retomada quando do término do benefício. Precedentes. Não conhecido. DANOS MORAIS. HONORÁRIOS ADVOCATÍCIOS. AUSÊNCIA DE PREQUESTIONAMENTO. As matérias não foram prequestionadas, nos termos da Súmula 297 desta Corte. Recurso de revista não conhecido.

(RR - 116700-15.2007.5.15.0085 , Relator Ministro: Emmanoel Pereira, Data de Julgamento: 09/11/2011, $5^{\text {a }}$ Turma, Data de Publicação: DEJT 18/11/2011)

Como se evidencia, a jurisprudência oscila sobre o tema, cabendo ao operador do direito redobrada atenção às extinções contratuais nessa situação, sob risco de ser compreendida a prorrogação do contrato a termo. 


\subsubsection{Efeitos da dispensa sem justa causa no curso da suspensão contratual}

Anteriormente vimos que a dispensa sem justa causa ocorrida no curso da suspensão contratual é um ato nulo (artigos 9, 471 e 476 da CLT e artigo 63 da Lei 8.213/91).

Agora, necessário abordar as consequências jurídicas do ato demissional nulo. Inicialmente, saliente-se que não há qualquer correlação entre a teoria das nulidades do contrato de trabalho com a nulidade da dispensa, por se tratarem de tema completamente diverso.

Pela teoria geral civilista das nulidades do ato jurídico, o ato nulo não produz qualquer efeito jurídico, restituindo-se as partes ao estado em que antes dele se achavam, conforme determinado no artigo 182 do Código Civil:

Art. 182. Anulado o negócio jurídico, restituir-se-ão as partes ao estado em que antes dele se achavam, e, não sendo possível restituílas, serão indenizadas com o equivalente.

A restituição do status quo ante, no Direito do Trabalho, implica no restabelecimento do contrato de trabalho, com a consequente reintegração do trabalhador ao emprego.

A CLT prevê, expressamente, a reintegração na dispensa inválida de empregado estável, conforme previsto no artigo 495 e 496:

Art. 495 - Reconhecida a inexistência de falta grave praticada pelo empregado, fica o empregador obrigado a readmiti-lo no serviço e a pagar-Ihe os salários a que teria direito no período da suspensão.

Art. 496 - Quando a reintegração do empregado estável for desaconselhável, dado o grau de incompatibilidade resultante do dissídio, especialmente quando for o empregador pessoa física, o tribunal do trabalho poderá converter aquela obrigação em indenização devida nos termos do artigo seguinte. 
Evidenciam-se pelos dispositivos transcritos que as normas trabalhistas estabelecem o status quo ante (restabelecimento do contrato de trabalho com os salários do período) e, quando desaconselhável (em razão do caráter intuito persoane do contrato de trabalho), sua conversão em perdas e danos (indenização dobrada, no caso).

Do mesmo modo, a dispensa nula no contrato de trabalho suspenso ocasiona o restabelecimento do contrato de trabalho e a reintegração do trabalhador. Didaticamente, pode-se afirmar que, no plano jurídico, o contrato de trabalho volta a ter sua vigência restabelecida e, no plano fático, o empregado retorna ao trabalho.

Não raramente, ocorre de o empregado permanecer incapacitado e não retornar ao trabalho. Nessas situações, apenas haverá o restabelecimento do contrato de trabalho (plano jurídico), o qual permanecerá suspenso até a alta médica do empregado e, por consequente, seu retorno ao trabalho (plano fático).

Esclareça-se que, durante esse período em que o empregado aguardou a declaração judicial de nulidade de sua dispensa até o restabelecimento do contrato de trabalho, detém todos os direitos e vantagens inerentes ao contrato de trabalho suspenso, como anteriormente abordados (recordando-se que por estar licenciado sem remuneração em gozo do auxíliodoença, não há que se falar em salários do período, conforme artigo 476 da CLT e artigo 63 da Lei 8.213/91). Esses direitos e vantagens serão convertidos em indenização equivalente (artigo 182 do Código Civil por autorização do artigo $8^{\circ}$, parágrafo único, da CLT).

Nesse sentido, colaciona-se a seguinte jurisprudência do Tribunal Superior do Trabalho: 
FOI MANTIDO PELO EMPREGADOR DURANTE A SUSPENSÃO DO CONTRATO DE TRABALHO. A tese da empresa agravante é de que não há falar em nulidade da rescisão do contrato de trabalho, pois não há comprovação de que a autora encontrava-se incapacitada para o trabalho e, em gozo de benefício previdenciário (auxílio-doença), quando da respectiva dispensa. A tese do e. Tribunal Regional é de nulidade da rescisão do contrato de trabalho, tendo em vista que este encontrava-se suspenso quando se deu a dispensa (2/8/2007), por motivo de doença (câncer) diagnosticada em 2002 e que, ainda, cujo tratamento ainda está em andamento. Incidência da Súmula $n^{\circ} 126 /$ TST.

(AIRR - 12000-32.2009.5.05.0461, Relator Ministro: Alexandre de Souza Agra Belmonte, Data de Julgamento: 22/10/2014, $3^{\text {a }}$ Turma, Data de Publicação: DEJT 24/10/2014) - Ementa parcial.

Há algumas situações, diante do interregno temporal, que a dispensa sem justa causa tenha ocorrido durante a suspensão contratual, mas existente a alta médica antes de apreciação judicial do pedido de reintegração.

Nesses casos, há dois entendimentos jurídicos a respeito: a) a dispensa teria se concretizado no momento da alta médica, sem reintegração; e b) por ser a dispensa nula, há o direito de reintegração e o contrato de trabalho somente poderá ser extinto por novo ato do empregador.

O primeiro entendimento se funda na ausência de qualquer estabilidade do empregado após a cessação da suspensão contratual, podendo ser extinto a qualquer momento a partir de então.

O segundo entendimento, tem o condão de restabelecer o contrato de trabalho em sua integralidade, devidos inclusive os salários entre a alta médica (no caso, previdenciária) e a efetiva reintegração. Nesse sentido:

AGRAVO. AGRAVO DE INSTRUMENTO EM RECURSO DE REVISTA. JULGAMENTO EXTRA PETITA. NÃO CONFIGURAÇÃO. NULIDADE DA DISPENSA SEM JUSTA CAUSA EFETUADA DURANTE A SUSPENSÃO DO CONTRATO EM RAZÃO DE AUXÍLIO-DOENÇA. Correta a decisão que manteve o entendimento acerca da inviabilidade de resilição unilateral de contrato de trabalho por ato do empregador no período de sustação dos efeitos contratuais (art. 471 da CLT). A dispensa obreira injusta ou desmotivada (isto é, sem os motivos considerados justos pela lei) é vedada nas situações suspensivas. Assim, a decisão agravada foi proferida em estrita observância aos artigos 896, $\S 5^{\circ}$, da CLT, e 557, caput, do CPC, 
razão pela qual é insuscetível de reforma ou reconsideração. Mantém-se, pois, a decisão agravada. Agravo desprovido.

(Ag-AIRR - 51000-29.2006.5.01.0017 , Relator Ministro: Mauricio Godinho Delgado, Data de Julgamento: 27/08/2014, $3^{\text {a }}$ Turma, Data de Publicação: DEJT 29/08/2014)

Onde se encontrou a manutenção da seguinte decisão Regional:

A outra controvérsia estabelecida nesses autos limita-se à validade do rompimento do contrato de trabalho pelo empregador em período que o empregado se encontrava afastado pelo INSS, recebendo auxíliodoença.

O empregado pretende apenas a reintegração ao posto de serviço por ter sido dispensado durante a suspensão do contrato de trabalho.

... determino a sua imediata reintegração aos quadros da ré, no prazo de dez dias, sob pena de multa diária de $\mathrm{R} \$ 500,00$, a partir da citação do empregador, e pagamento dos salários vencidos e vincendos, em sentido estrito, a partir de 2/12/2005, ocasião da alta médica pelo ente previdenciário.

Com efeito, compreendida nula a dispensa realizada no curso da suspensão contratual, necessário o restabelecimento do status quo ante. Somente um novo ato jurídico válido poderá extinguir o contrato de trabalho.

Isso significa que nada impede de o empregador realizar nova dispensa após a alta médica do empregado, ainda que durante a discussão judicial sobre a validade da primeira dispensa. Competirá a ele, no entanto, levar ao conhecimento do juízo esse novo ato de dispensa (artigo 818 da CLT) a fim de que seja observado quando do julgamento da lide (artigo 462 do CPC).

Caso o empregador opte por não realizar uma nova dispensa (válida), o restabelecimento do contrato de trabalho após certo período de discussão judicial acarretará um enorme prejuízo ao empregador.

Todavia, esse não é um argumento jurídico para se compreender que a extinção contratual ocorre após a alta médica do empregado, com a cessação da 
suspensão do contrato de trabalho, tal qual a dispensa sem justa causa equivalesse a um ato sob condição suspensiva ${ }^{193}$.

Registre-se que o raciocínio lógico-jurídico desse último entendimento não encontra guarida na Súmula 396, I, do TST, que trata de estabilidade provisória, o que analisaremos a seguir.

\subsubsection{Garantia de emprego}

A suspensão do contrato de trabalho por motivo de incapacidade laborativa não ocasiona, em todas as situações, o direito de continuidade do contrato de trabalho.

A incapacidade laborativa em decorrência de acidente de trabalho ${ }^{194}$ pode garantir o emprego ao trabalhador por certo período, conforme dispõe o artigo 118 da Lei 8.213/91:

Art. 118. O segurado que sofreu acidente do trabalho tem garantida, pelo prazo mínimo de doze meses, a manutenção do seu contrato de trabalho na empresa, após a cessação do auxílio-doença acidentário, independentemente de percepção de auxílio-acidente.

Não há mais discussão sobre a constitucionalidade do referido dispositivo legal diante do pronunciamento do Supremo Tribunal Federal em ação direta de inconstitucionalidade. ${ }^{195}$

Em razão de o dispositivo mencionar "após a cessação do auxíliodoença acidentário", consagrou-se o entendimento de que os afastamentos de até 15 (quinze) dias, em que não há recebimento de auxílio-doença, não resultam em direito à estabilidade. ${ }^{196}$

\footnotetext{
${ }^{193}$ Recorde-se que a condição suspensiva, enquanto não se verificar, não se terá adquirido o direito (artigo 125 do Código Civil), o que não se confunde com os efeitos da nulidade de ato jurídico.

${ }^{194}$ A definição de acidente do trabalho está prevista nos artigos 19, 20 e 21 da Lei 8.213/91

${ }^{195}$ Vide Ação Direta de Inconstitucionalidade nº 639/DF do Supremo Tribunal Federal.

${ }^{196}$ Registre-se o entendimento minoritário de que apenas os empregados que permaneceram com sequelas teriam direito à garantia de emprego em razão da expressão "independentemente de
} 
Nesse ponto, a primeira parte da Súmula 378, II, do TST:

378. Estabilidade provisória. Acidente de trabalho. Art. 118 da Lei $n^{\circ}$ 8.213/91. (Conversão das Orientações Jurisprudenciais ns 105 e 230 da SDI-1 - Res. 129/2005, DJ 20.04.2005 - Inserido o item III pela Resolução n 185/2012, DeJT 25.09.2012)

$\ldots$

II - São pressupostos para a concessão da estabilidade o afastamento superior a 15 dias e a conseqüente percepção do auxílio-doença acidentário, salvo se constatada, após a despedida, doença profissional que guarde relação de causalidade com a execução do contrato de emprego. (primeira parte - ex-OJ n 230 da SBDI-1 - inserida em 20.06.2001)

Assim, há dois pressupostos para a concessão da garantia de emprego: a) afastamento superior a 15 (quinze) dias; e b) percepção do auxíliodoença acidentário.

Quanto ao primeiro pressuposto, há de se observar que a Medida Provisória 664/2014 revogou o artigo 59 da Lei 8.213/91 e fixou nova redação do artigo 60 da Lei 8.213/91 (com vigência a partir de 01/03/2015), para o fim de estabelecer que o auxílio-doença é devido a partir do $31^{\circ}$ dia de trabalho.

Nessa linha de raciocínio, somente os afastamentos superiores a 30 (trinta) dias, ocorridos na vigência da nova redação, possibilitam a garantia de emprego estabelecida no artigo 118 da Lei 8.213/91.

Assim, a referida medida provisória não somente alterou a concessão dos benefícios previdenciários, como também proporcionou verdadeiro retrocesso social quanto à garantia de emprego do trabalhador acidentado ${ }^{197}$.

percepção de auxílio-acidente", que se cogita apenas quando há sequela acidentária. Prevalece o entendimento de que "independente" se refere à desnecessidade de recebimento do benefício para fins de aquisição do direito.

${ }^{197}$ A referida Medida Provisória é objeto de ações diretas de inconstitucionalidade no Supremo Tribunal Federal (ADI n 5.230, 5.232, 5.234 e 5.238), de Relatoria do Ministro Luiz Fux, sob os principais fundamentos: a) falta de relevância e urgência para edição de medida provisória; b) regulamentação de comando constitucional alterado por emenda aprovada entre 1995 e 2001; c) violação aos princípios da dignidade da pessoa humana, da proporcionalidade e da isonomia, resultando em inadmissível retrocesso social; d) reciprocidade no princípio da prévia fonte de 
O segundo requisito (concessão do auxílio-doença acidentário) ocasiona diversos transtornos insuperáveis pela interpretação literal do dispositivo:

Surgem diversas diversas hipóteses de transtornos, tais como aquela: a) em que o empregador não paga os quinze dias e dificulta o acesso à Previdência; b) o empregado ainda não detém a qualidade de segurado; c) o INSS cataloga o benefício como previdenciário (código 31) quando o correto seria acidentário (código 91); e d) a doença é descoberta quando já rescindido o contrato de trabalho. ${ }^{198}$

Pode-se ainda acrescentar o problema do empregado aposentado, eis que vedada legalmente o recebimento acumulado de auxílio-doença com aposentadoria (art. 124, I, da Lei 8.213/91).

Há entendimento de que o empregado aposentado simplesmente não detém garantia de emprego:

Nota-se que a garantia de emprego só é devida após a cessação do auxílio-doença acidentário. Logo, inexistindo direito ao auxílio-doença acidentário, não é devida a garantia de emprego. É o que o ocorre, v. g., no caso do segurado que percebe aposentadoria especial, por idade ou por tempo de serviço e que não tem direito ao auxíliodoença acidentário (arts. 18, $2^{\circ}, 121$, da Lei 8.213/91), não fazendo jus, portanto, à garantia de emprego em comentário ${ }^{199}$.

A parte final da redação da Súmula 378, II, do TST, passou a admitir a existência de garantia de emprego sem a concessão do auxílio-doença:

...tem sido suplantada por interpretação teleológica, admitindo-se que o empregado se valha de outros meios de prova na tentativa de associar sua doença ao contrato de trabalho e, assim, obter êxito na

custeio, alegando que se a Previdência não pode pagar mais que o devido, também não pode pagar menos com a mesma arrecadação.

Fonte: Secretaria de Comunicação Social do STF. Questionadas MPs que alteraram benefícios trabalhistas e previdenciários. Artigo publicado em 03 de fevereiro de 2015. Disponível em: 26 fev 2015.

$<$ http://www.stf.jus.br/portal/cms/verNoticiaDetalhe.asp?idConteudo=284624>; acesso em ${ }^{198}$ SILVA, op. cit., 2013, p. 393.

${ }^{199}$ MARTINS, op. cit., 2005, p. 449. 
pretensão à garantia de emprego sem que necessariamente tenha passado pelo crivo do auxílio-doença acidentário. ${ }^{200}$

Nesse sentido, perfeito o ensinamento de Cláudia Salles Vilela Vianna ${ }^{201}$ quanto ao empregado aposentado:

Quando se tratar de CAT emitida pela própria empresa, reconhecendo o fato como acidente de trabalho, desnecessária se faz a real percepção do benefício previdenciário para se ver reconhecido o direito de estabilidade, sendo suficiente que a incapacidade supere o lapso temporal de quinze dias.

A se partir da premissa de que as relações jurídicas previdenciárias são independentes das relações jurídicas trabalhistas, por terem regime jurídico e princípios próprios ${ }^{202}$, não há motivo de se excluir a garantia de emprego ao empregado aposentado acidentado pelo fato de não poder receber benefício previdenciário de auxílio-doença.

A finalidade da norma do artigo 118 da Lei 8.213/91 é propiciar a garantia ao emprego do empregado que sofrer acidente de trabalho que lhe tenha afastado por mais de 15 dias (ou 30 dias após a MP 664/2014) do emprego, independentemente da percepção do auxílio-doença acidentário.

Nessa concepção, concordamos que a redação do artigo 118 da Lei 8.213/91 apenas referenciou a cessação do benefício para o fim de contagem do termo inicial da garantia de emprego:

\footnotetext{
${ }^{200}$ SILVA, Homero Batista Mateus da. op. cit., 2009, p. 393.

${ }^{201}$ VIANNA, Cláudia Salles Vilela, op. cit., 2010, p. 106.

${ }^{202}$ Relembre-se que, por essas razões, o Supremo Tribunal Federal decidiu que a aposentadoria voluntária não extingue o contrato de trabalho. Confira: EMENTA: Previdência social: aposentadoria espontânea não implica, por si só, extinção do contrato de trabalho. 1. Despedida arbitrária ou sem justa causa (CF, art. $\left.7^{\circ}, \mathrm{I}\right)$ : viola a garantia constitucional o acórdão que, partindo de premissa derivada de interpretação conferida ao art. 453, caput, da CLT (redação alterada pela L. 6.204/75), decide que a aposentadoria espontânea extingue o contrato de trabalho, mesmo quando o empregado continua a trabalhar na empresa após a concessão do benefício previdenciário. 2. A aposentadoria espontânea pode ou não ser acompanhada do afastamento do empregado de seu trabalho: só há readmissão quando o trabalhador aposentado tiver encerrado a relação de trabalho e posteriormente iniciado outra; caso haja continuidade do trabalho, mesmo após a aposentadoria espontânea, não se pode falar em extinção do contrato de trabalho e, portanto, em readmissão. 3. Precedentes (ADIn 1.721-MC, IImar Galvão, RTJ 186/3; ADIn 1.770, Moreira Alves, RTJ 168/128). RE 449420 / PR - PARANÁ Relator(a): Min. SEPÚLVEDA PERTENCE Julgamento: 16/08/2005 Primeira Turma.
} 
A aquisição do direito à garantia fixada no art. 118 da Lei 8.213/91 independe, na essência, da obtenção de auxílio-doença acidentário. A menção a tal benefício, no texto legal, tem o objetivo de marcar o início da contagem do prazo estabilitário. ${ }^{203}$

Nem mesmo a exigência prevista em norma coletiva de que a garantia de emprego somente seria devida por atestado da autarquia previdenciária prevalece, porquanto possível a demonstração da incapacidade laborativa e nexo causal no processo judicial:

\begin{abstract}
Por isso se conclui que nem sempre o laudo do INSS prevalece, não havendo nisso nenhum desdouro, seja para a previdência social, seja para as partes em juízo.

Não fosse assim, isto é, não estivesse garantido o direito de ingressar em juízo para contestar a perícia médica da previdência social, estarse-ia excluindo da apreciação do Poder Judiciário eventual lesão a direito do segurado (CF, art. $5^{\circ}, \mathrm{XXXV}$ ).

Assim, correta a supressão da Orientação Jurisprudencial n. 154, da SBDI-I do TST, que dispunha ser necessário o laudo do INSS, conforme disposto em instrumento normativo, a comprovar doença profissional, para gerar estabilidade no emprego. ${ }^{204}$
\end{abstract}

RECURSO DE EMBARGOS INTERPOSTO SOB A ÉGIDE DA LEI N. ${ }^{\circ}$ 11.496/2007. GARANTIA PROVISÓRIA DE EMPREGO PREVISTA EM NORMA COLETIVA. DOENÇA PROFISSIONAL. EXIGÊNCIA DE ATESTADO MÉDICO EXPEDIDO PELO INSS. 1. Esta Corte uniformizadora havia sedimentado, por meio da Orientação Jurisprudencial n. ${ }^{\circ} 154$ da SBDI-I, entendimento no sentido de que a doença profissional deve ser atestada por médico do INSS, se tal exigência consta de cláusula de instrumento normativo, sob pena de não reconhecimento do direito à estabilidade. Entretanto, o Tribunal Pleno do TST cancelou a referida orientação, por intermédio da Resolução n. ${ }^{\circ}$ 158/2009, publicada no DJET em 21, 22 e 23/10/2009. 2. A partir daí, passou a jurisprudência majoritária desta Corte superior a reputar inexigível o atestado do INSS para o reconhecimento da garantia provisória de emprego, ainda que existente previsão nesse sentido em norma coletiva. 3. Irretocável, nesse contexto, a decisão proferida pela Turma no sentido de não conhecer do recurso de revista interposto pela reclamada. 4. Recurso de embargos conhecido e não provido" (TST-E-RR-23100027.2000.5.02.0463, SBDI-1, Rel. Min. Lelio Bentes Corrêa, DEJT 04/04/2014).

A interpretação teleológica do mencionado dispositivo pela parte final da Súmula 378, II, do TST, ressalva-se a garantia de emprego desprovida de

${ }^{203}$ MAIOR, Jorge Luiz Souto. Doença profissional: aplicação do art. 118 da Lei 8.213/91. Ausência de auxílio-doença. Boletim Informativo do TRT - 15ª . Região. Campinas, nº. 186, p. 59-67, jan./fev. 2004.

${ }^{204}$ CARDONE, op. cit., 2011, p. 134. 
auxílio-doença acidentário "salvo se constatada, após a despedida, doença profissional que guarde relação de causalidade com a execução do contrato de emprego".

Em análise acurada dos precedentes do referido item sumular, verificase que o entendimento derivou da aplicação do artigo 129 do Código Civil em relação à ausência de emissão de Comunicação de Acidente de Trabalho - CAT por parte do empregador, que teria obstado o benefício previdenciário.

Atualmente, a jurisprudência do Tribunal Superior do Trabalho aplica a parte final da Súmula 378, II, como uma possibilidade autônoma da garantia de emprego:

\begin{abstract}
ESTABILIDADE. ARTIGO 118 DA LEI No 8.213/91. DOENÇA PROFISSIONAL. INEXIGIBILIDADE DA PERCEPÇÃO DE AUXÍLIO DOENÇA E DO AFASTAMENTO POR MAIS DE 15 DIAS. A decisão recorrida revela consonância com a Súmula $n^{\circ} 378$ desta Corte uniformizadora, mediante a qual se consagrou tese no sentido de que, uma vez comprovado o nexo da causalidade entre a doença profissional e a execução do contrato de emprego, não se exige a percepção de auxílio-doença e o afastamento por mais de 15 dias para o reconhecimento da estabilidade de que trata o artigo 118 da Lei $n^{\circ} 8.213 / 91$. Não se viabiliza do seguimento do recurso de revista, nos termos do artigo 896, § $5^{\circ}$, da Consolidação das Leis do Trabalho. Agravo de instrumento a que se nega provimento. Ementa parcial. ( AIRR - 25700-68.2004.5.05.0132 , Relator Ministro: Lelio Bentes Corrêa, Data de Julgamento: 24/09/2014, $1^{\text {a }}$ Turma, Data de Publicação: DEJT 26/09/2014)
\end{abstract}

Isso porque não há indagações sobre o grau da incapacidade laborativa (total ou parcial) em relação à profissão ou atividade que o empregado habitualmente exercia (requisito indispensável para o afastamento das atividades laborativas) e, muitas vezes, nem sobre o período em que se revelar a incapacidade para as atividades que habitualmente exercia.

O Tribunal Superior do Trabalho trata a doença ocupacional que produz a incapacidade laborativa parcial (ou déficit funcional) da mesma forma que a incapacidade total, criando garantia de emprego vitalícia para as 
incapacidades indefinidas, algo completamente alheio à sistemática jurídica da matéria.

Entendemos que a garantia de emprego estabelecida no artigo $118 \mathrm{da}$ Lei 8.213/91 tem como escopo proteger o empregado acidentado (incluindo doença ocupacional ou equiparados) da dispensa injustificada quando a incapacidade para a sua profissão ou atividade habitual estiver demonstrada, por período superior a 15 dias (ou 30 dias após a MP 664/2014) independentemente da percepção do benefício de auxílio-doença acidentário. Entretanto, a existência de incapacidade total deve ser demonstrada, ainda que decorrente de doença ocupacional, para a aquisição da garantia de emprego.

\begin{abstract}
Num primeiro momento, observa-se a incapacidade total para o trabalho, resultante do acidente do trabalho. Portanto, o trabalhador fica afastado de todo e qualquer trabalho. Num segundo, porém, constata-se que, após consolidadas as lesões, o trabalhador recupera parcialmente sua capacidade de trabalhar. Por exemplo: perda de audição do ouvido acidentado, perda de acuidade visual no olho acidentado, perda de um rim etc. Nesta última situação, curadas as lesões, resta ao trabalhador capacidade parcial para o trabalho. Pode ele retornar à atividade remunerada, com restrições. Daí por que the são devidos determinados benefícios decorrentes da perda parcial da capacidade de trabalho. ${ }^{205}$
\end{abstract}

Todavia, de acordo com a atual jurisprudência do Tribunal Superior do Trabalho, a extinção contratual somente pode ocorrer após recuperação integral do empregado, o que, eventualmente, pode jamais ocorrer.

No que tange ao empregado doméstico, a previdência social não lhe concede auxílio-doença acidentário, pois está expressamente excluído no artigo 336 do Decreto 3.048/99 e artigo 318, §1ํㅡ, da IN INSS/PRES ํo 77, de 21/01/2015, (a própria definição de acidente de trabalho exclui o trabalho doméstico, na medida em que exige trabalho a serviço da empresa - artigo 19 da Lei 8.213/91).

${ }^{205}$ GONÇALVES, Odonel Urbano. Manual de Direito Previdenciário. Acidentes do Trabalho. 10. ed. São Paulo: Atlas, 2002, p. 199. 
Todavia, de se obtemperar que a EC 72/2013 alterou a redação do parágrafo único do artigo $7^{\circ}$ da Constituição Federal, para garantir ao empregado doméstico:

XXII - redução dos riscos inerentes ao trabalho, por meio de normas de saúde, higiene e segurança.

Destarte, o comando constitucional inseriu o trabalhador doméstico nas normas de proteção inerentes ao ambiente do trabalho. Diante da força normativa desse direito fundamental, não há mais razão em excluir o doméstico da garantia de emprego prevista no artigo 118 da Lei 8.213/91, quando o acidente ocorrer no ambiente de trabalho, porquanto a estabilidade provisória ao empregado acidentado é corolário das normas de segurança do trabalho não justificando, pois, a distinção de tratamento entre os trabalhadores.

No entanto, registre-se que o entendimento ainda majoritário, porquanto não se encontrou registros jurisprudenciais em sentido oposto que fossem posteriores à Emenda Constitucional, permanece pela ausência de direito de estabilidade provisória ao empregado doméstico.

\subsubsection{Previsão em instrumento normativo}

Existe importante matéria que não pode passar despercebida: a garantia de emprego prevista em instrumentos normativos.

As normas coletivas podem estabelecer estabilidade provisória ao empregado, em razão da incapacidade laborativa por motivo de doença, relacionada ou não ao trabalho (artigos $7^{\circ}, \mathrm{XXVI}$ da CF e artigo 611 da CLT).

llustra-se a respeito, cláusula da Convenção Coletiva dos Bancários FENABAN/CONTRAF (2014/2015): 
CLÁUSULA 26a - ESTABILIDADES PROVISÓRIAS DE EMPREGO Gozarão de estabilidade provisória no emprego, salvo por motivo de justa causa para demissão:

c) doença : Por 60 (sessenta) dias após ter recebido alta médica, quem, por doença, tenha ficado afastado do trabalho, por tempo igual ou superior a 6 (seis) meses contínuos;

d) acidente: Por 12 (doze) meses após a cessação do auxílio doença acidentário, independentemente da percepção do auxílio acidente, consoante artigo 118 da Lei 8213, de 24.07.1991;

O que há de relevante na questão é que os instrumentos normativos têm prazo máximo de vigência fixado em lei (acordos e convenções de dois anos - artigo 614, $\S 2^{\circ}$, da CLT; e sentença normativa de quatro anos - artigo 868, parágrafo único, da CLT) e problemas de aplicabilidade da norma passaram a ocorrer em razão de as normas não estarem mais vigentes.

O Tribunal Superior do Trabalho pacificou a questão por meio da Orientação Jurisprudencial 41 da Seção de Dissídios Individuais I:

\begin{abstract}
41 - Estabilidade. Instrumento normativo. Vigência. Eficácia. (Inserida em 25.11.1996)

Preenchidos todos os pressupostos para a aquisição de estabilidade decorrente de acidente ou doença profissional, ainda durante a vigência do instrumento normativo, goza o empregado de estabilidade mesmo após o término da vigência deste.
\end{abstract}

No cotidiano da Justiça do Trabalho, encontrou-se situação em que a norma coletiva previa a estabilidade até a recuperação integral ou aposentadoria do trabalhador acidentado no caso de sequelas (Dissídio Coletivo de 1991: Irmandade da Santa Casa de Misericórdia de São Paulo x SINSAUDESP):

Cláusula $18^{\mathrm{a}}$ - Estabilidade ao empregado vitimado por acidente de trabalho até 60 (sessenta) dias após a alta; havendo sequelas, a estabilidade perdurará enquanto as mesmas não desaparecerem ou até a aposentadoria pelo órgão competente, devendo a empresa efetuar o seu reaproveitamento em função compatível com seu estado físico, sem prejuízo de seus vencimentos.

Assim, aqueles acidentados na vigência da referida norma coletiva que permaneceram com sequelas, estão acobertados pela estabilidade até 0 
desaparecimento das sequelas ou até a aposentadoria, transpondo, evidentemente, os limites de vigência da referida norma coletiva.

O precedente do verbete acima transcrito, em cláusula semelhante, explica em sua fundamentação que:

A cláusula em comento operou efeitos para o futuro, no estrito sentido de prever a estabilidade provisória para o empregado que adquiriu doença profissional durante sua vigência para além do prazo de sua validade...

Neste caso, o trabalhador acometido por moléstia durante o vigor da norma coletiva seria detentor da estabilidade provisória enquanto perdurasse o seu mal e não somente durante o curto lapso temporal de uma Convenção Coletiva. ${ }^{206}$

Trata-se, pois, de direito adquirido ${ }^{207}$ ao tempo em que a norma vigorava, que está ileso a norma jurídica posterior.

\subsubsection{No contrato a termo}

A discussão sobre a aplicabilidade do artigo 472, $2^{\circ}$, da CLT, anteriormente abordada, também invadiu a seara da estabilidade provisória.

Por muito tempo, o Tribunal Superior do Trabalho entendeu que a garantia de emprego não era aplicável nos contratos a termo, como sintetizado por Homero Batista Mateus da Silva ${ }^{208}$, ao analisar a Súmula 371 do TST:

"Por esse conceito: a) o empregador deve pagar os quinze primeiros dias, ainda que sua inclusão extrapole os trinta dias do aviso-prévio; b) o empregado encaminhado para o INSS que obtiver o auxíliodoença acidentário fica com o contrato de trabalho suspenso; c) ao retornar, após a alta previdenciária, opera-se a baixa na Carteira de Trabalho, sem direito à garantia de emprego de doze meses de que cuida o artigo 118 da Lei 8.213/91".

\footnotetext{
${ }^{206}$ ERR 42709/1992, Ac. 3415/1996 - Min. Armando de Brito DJ 09.08.1996

${ }^{207}$ Art. $5^{\circ}$ Todos são iguais perante a lei, sem distinção de qualquer natureza, garantindo-se aos brasileiros e aos estrangeiros residentes no País a inviolabilidade do direito à vida, à liberdade, à igualdade, à segurança e à propriedade, nos termos seguintes: ... XXXVI - a lei não prejudicará o direito adquirido, o ato jurídico perfeito e a coisa julgada;

${ }^{208}$ SILVA, Homero Batista Mateus da, op. cit., 2013, p. 357.
} 
A questão apenas foi pacificada, em sentido contrário, após a edição da Súmula 378, III, do TST:

III - O empregado submetido a contrato de trabalho por tempo determinado goza da garantia provisória de emprego, decorrente de acidente de trabalho, prevista no art. 118 da Lei no 8.213/91.

O fundamento do referido verbete jurisprudencial deriva de raciocínio muito simples: não há distinção entre contrato por tempo indeterminado e contrato a termo no artigo 118 da Lei 8.213/91, não cabendo ao intérprete em fazê-la.

O mesmo ocorre no caso de concessão de auxílio-doença-acidentário (B.91) no curso do aviso prévio, que também está acobertado pela garantia de emprego:

RECURSO DE REVISTA. AVISO PRÉVIO INDENIZADO. SUPERVENIEENCIA DE AUXÍLIO-DOENÇA. PERÍODO ESTABILITÁRIO EXAURIDO. EFEITOS. No caso de concessão de auxílio-doença no curso do aviso prévio só se concretizam os efeitos da dispensa depois de expirado o benefício previdenciário. Tal circunstância não afasta o direito do empregado à estabilidade provisória prevista no art. 118 da Lei $n^{\circ} 8.213 / 914$, nos termos das Súmulas 371 e 378 , II, do TST. Contudo, exaurido o período de estabilidade, são devidos apenas os salários e vantagens do interregno de doze meses após o final do benefício previdenciário, sem a reintegração no emprego (Súmula 396, I, do TST). Recurso de revista conhecido e parcialmente provido.

(RR - 907-77.2012.5.04.0402, Relator Ministro: Alberto Luiz Bresciani de Fontan Pereira, Data de Julgamento: 11/02/2015, $3^{\text {a }}$ Turma, Data de Publicação: DEJT 20/02/2015)

Essa jurisprudência nos parece ter situado perfeitamente a questão: a suspensão do contrato a termo não interfere na aquisição da garantia de emprego do empregado acidentado.

A sistemática jurídica que estamos a defender, de que há apenas a suspensão da prestação de fazer por parte do empregado em razão de fortuito, com a respectiva vigência das demais cláusulas contratuais, implica na aquisição de todos os direitos e vantagens originados no contrato de trabalho, com as ressalvas antes estudadas, o que não seria diferente em relação à aquisição do 
direito de garantia de emprego previsto no artigo 118 da Lei 8.213/91. Irrelevante, pois, o prazo determinado ou indeterminado do contrato de trabalho.

\subsubsection{Efeitos da dispensa sem justa causa no curso da garantia de emprego}

Garantido o emprego pela norma jurídica durante certo período de tempo, a extinção contatual sem justa causa tem como principal efeito a nulidade do ato (artigo $9^{\circ}$ da CLT).

Da mesma forma, nula a concessão do aviso prévio na vigência de garantia de emprego, diante da incompatibilidade entre os institutos, conforme Súmula 348 do TST:

348 - Aviso prévio. Concessão na fluência da garantia de emprego. Invalidade (Res. 58/1996, DJ 28.06.1996)

É inválida a concessão do aviso prévio na fluência da garantia de emprego, ante a incompatibilidade dos dois institutos.

Tal qual a extinção sem justa causa no curso da suspensão contratual, a nulidade do ato implica no restabelecimento do estado em que se encontravam anteriormente (artigo 182 do Código Civil), o que significa em restabelecimento do contrato de trabalho que, no âmbito trabalhista, trata-se da reintegração.

Estatuindo a lei as hipóteses nas quais poderá ocorrer a extinção do contato de trabalho do empregado estável e o procedimento que deve ser observado para esse fim, evidenciou, de maneira incontroversa, que o vínculo contratual deverá ser restabelecido sempre que rescindido com desatenção às normas legais pertinente. É que a estabilidade tem por finalidade a sobrevivência do contrato de trabalho, assegurando ao trabalhador o direito ao emprego ainda que em caráter transitório sujeito a condição resolutiva. ${ }^{209}$

${ }^{209}$ SÜSSEKIND, Arnaldo; MARANHÃO, Délio; VIANNA, Segadas; TEIXEIRA, Lima. Instituições de Direito do Trabalho. 22. ed. São Paulo: LTr, 2005. 
Somente quando não for possível o restabelecimento do estado anterior (artigo 182 do Código Civil) ou for desaconselhável dado o grau de incompatibilidade (por analogia, o artigo 496 da CLT), a reintegração seria substituída por indenização equivalente.

A reintegração ao emprego, além atribuir exatamente os efeitos previstos na lei em razão da dispensa nula, ainda produz efeitos divergentes de sua conversão em indenização, principalmente:

a) permanência do empregado como segurado obrigatório da Previdência Social por mais tempo - a reintegração implica na retificação das informações mensais à previdência social, conforme, artigo 32, IV, da Lei 8.212/91, por meio das Guias de Recolhimento do FGTS e Informações à Previdência Social - GFIP que comporão a base de dados para fins de cálculo e concessão de benefícios previdenciários (art. $32, \S 2^{\circ}$ da Lei 8.212/91) - fato de suma importância para a manutenção previdenciária do trabalhador (art. $6^{\circ} \mathrm{e}$ art. 201 da CF); e

b) a restauração do contrato de trabalho possibilita a aquisição de nova garantia de emprego em seu curso (como pré-aposentadoria, eleição a cargo da CIPA ou dirigente sindical, entre outras), o que fica completamente obstada pela conversão em mera indenização.

A conversão em indenização, como regra geral, tal como prevista na Súmula 396, I, do TST, ainda tem o condão de favorecer o empregador recalcitrante, que defende a validade de seu ato nulo até a última instância judicial, e cria situação jurídica inacreditável: o ato nulo de dispensa passa a produzir plenos efeitos porque a extinção contratual permanece intocada e garante direito à indenização (perdas e danos dessa mesma nulidade) limitado ao período estabilitário (como se pudesse presumir ato de dispensa válido ao final desse período). 
O mencionado verbete sumular dispõe que:

396 - Estabilidade provisória. Pedido de reintegração. Concessão do salário relativo ao período de estabilidade já exaurido. Inexistência de julgamento "extra petita". (Conversão das Orientações Jurisprudenciais nos 106 e 116 da SDI-1 - Res. 129/2005, DJ 20.04.2005)

I - Exaurido o período de estabilidade, são devidos ao empregado apenas os salários do período compreendido entre a data da despedida e o final do período de estabilidade, não the sendo assegurada a reintegração no emprego. . (ex-OJ no 116 - Inserida em 20.11.1997)

II - Não há nulidade por julgamento "extra petita" da decisão que deferir salário quando o pedido for de reintegração, dados os termos do art. 496 da CLT (ex-OJ no 106 - Inserida em 01.10.1997)

O que se extrai dos dois inciso é incrível: mesmo que o empregado somente requeira a reintegração, o juiz, de ofício, concederá apenas a indenização, porque o empregado não tem direito à reintegração.

Analisando os precedentes que chegaram a essa conclusão, nenhum deles decorrentes da garantia acidentária, verifica-se como principais fundamentos:

a) AR 142993/1994, Ac. 4644/1995-Min. Afonso Celso DJ 14.11.1994: que a indenização recebida substitui o direito à garantia contra a dispensa arbitrária (na hipótese, sequer foi requerida a reintegração);

b) ERR 84481/1993, Ac. 4729/1997-Min. Leonaldo Silva DJ 17.10.1997 - "O artigo 8, inciso VIII, da Constituição Federal, ao vedar a dispensa imotivada do empregado eleito para o cargo de dirigente sindical ou representante sindical não condiciona a estabilidade à reintegração no emprego, ainda mais quando já exaurido o período estabilitário e não se tem notícia de que tivesse o Empregado sido reeleito no cargo de dirigente sindical";

c) AGERR 162558/1995-Min. Vantuil Abdala DJ 20.02.1998 - "O art. 10, II, alínea "a", do ADCT não fora violado pela decisão 
recorrida na medida em que o dispositivo constitucional ao estender ao suplente da CIPA a estabilidade provisória, limitou a referida garantia até o prazo de um ano após o final do mandato do obreiro, pelo que não se pode deixar sem observação essa limitação temporal, o que obsta o acolhimento do pedido de reintegração no emprego";

d) AR 210412/1995, Ac. 1640/1996-Min. Vantuil Abdala DJ 21.02.1997 "Aliás, a jurisprudência desta Corte é pacífica no sentido de reconhecer ao membro da CIPA despedido sem justa causa, cujo período de garantia de emprego já se esgotara, apenas os salários desde a data da despedida até o termo do período estabilitário, mesmo porque a reintegração após este importaria em uma garantia de emprego superior à prevista na norma."

Observa-se das transcrições acima que o Tribunal Superior do Trabalho assentou sua jurisprudência sob o fundamento de que a reintegração significaria uma garantia de emprego superior àquela prevista na norma jurídica.

Em nenhum momento se analisa a nulidade do ato de dispensa, com o restabelecimento contratual, na forma do artigo 182 do Código Civil. Essa regra geral civilista, subsumida à questão, traduziria maior proteção ao empregado, por mais irônico que pareça.

Também não é verdade que a reintegração importa em garantia superior à norma, porquanto é consequência legal da dispensa nula. Nada impede que o empregador realize nova dispensa válida posteriormente.

Outrossim, não há dúvida de que o imenso prejuízo causado pelo restabelecimento do contrato, mesmo posterior ao período estabilitário, por exemplo, após todas esferas judiciais, decorre da prática de ato nulo e da recalcitrância de o empregador não reconhecer seu ato ilícito. Assim, causador direto de seus próprios transtornos (artigo 403 do Código Civil). Risco assumido por si, quando se trata de contrato de trato sucessivo. 
O que se pode concluir é que a atual jurisprudência do Tribunal Superior do Trabalho atribui maior proteção à suspensão do contrato de trabalho do que à própria garantia de emprego, na medida em que a reintegração é conferida na primeira hipótese, mas não na segunda:

Aviso prévio indenizado. Superveniência de auxílio-doença. Estabilidade provisória. Previsão em instrumento coletivo. Efeitos exclusivamente financeiros. Inviável a reintegração. Súmula $n^{\circ} 371$ do TST. A concessão do auxílio-doença no curso do aviso prévio indenizado apenas adia os efeitos da dispensa para depois do término do benefício previdenciário (Súmula $n^{\circ} 371$ do TST), e não implica em nulidade da despedida, ainda que norma coletiva assegure estabilidade provisória por sessenta dias após a concessão da alta médica. Desse modo, o empregado somente tem direito às vantagens econômicas previstas na norma coletiva, e, passado o período nela assegurado, pode o empregador extinguir o contrato de trabalho. Com esse entendimento, a SBDI-I, por unanimidade, conheceu dos embargos da reclamada por contrariedade à Súmula $\mathrm{n}^{\circ}$ 371 (má aplicação), e, no mérito, deu-lhes provimento para afastar a declaração da nulidade da dispensa e, consequentemente, a determinação de reintegração no emprego, reconhecendo que a condenação deve limitar-se a resguardar os direitos patrimoniais da reclamante até a concretização da dispensa, ocorrida no período de sessenta dias após o término do benefício previdenciário. (TST-E-EDRR-59000-67.2005.5.01.0012, SBDII, rel. Min. Renato de Lacerda Paiva, 12.3.2015).

Mas a reintegração ao emprego, por violação ao artigo 118 da Lei

8.213/91, ainda é admitida pelo o Tribunal Superior do Trabalho, quando deferida em medida liminar, na forma da Orientação Jurisprudencial $n^{\circ} 142$ da Seção de Dissídios Individuais II:

142. Mandado de segurança. Reintegração liminarmente concedida. (DJ 04.05.2004)

Inexiste direito líquido e certo a ser oposto contra ato de juiz que, antecipando a tutela jurisdicional, determina a reintegração do empregado até a decisão final do processo, quando demonstrada a razoabilidade do direito subjetivo material, como nos casos de anistiado pela da Lei $\mathrm{n}^{\circ}$ 8.878/94, aposentado, integrante de comissão de fábrica, dirigente sindical, portador de doença profissional, portador de vírus HIV ou detentor de estabilidade provisória prevista em norma coletiva. (Legislação: CLT, artigo 659, inciso $\mathrm{X}$ ) 
Assim, nas restritas hipóteses de concessão da medida liminar ocorrerá a reintegração do empregado, mas não em tutela definitiva após exaurimento do período de estabilidade.

No caso da concessão liminar de reintegração, restabelecido o contrato de trabalho, caberá ao empregador realizar nova dispensa após exaurimento do período estabilitário, por ato jurídico válido, se assim pretender. Raciocínio destruído pela Súmula 396, I, do TST.

Cabe ainda recordar que a reintegração realizada em razão da garantia de emprego fundada em doença ocupacional, em que a incapacidade parcial é indefinida, o retorno ao trabalho deverá ocorrer em atividade compatível ao estado de saúde do empregado, sob pena de ser considerada falta grave do empregador:

AGRAVO. AGRAVO DE INSTRUMENTO. RECURSO DE REVISTA. JUSTA CAUSA. ABANDONO DE CARGO. NÃO CARACTERIZAÇÃO. VALORAÇÃO DE FATOS E PROVAS. A parte agravante não apresenta argumentos novos capazes de desconstituir a juridicidade da decisão agravada, no sentido de que, no recurso de revista, não houve demonstração de violação de dispositivos da Constituição Federal (arts. 37, 93, IX) e de lei federal (arts. 482, "i", 483, § $3^{\circ}, 818$ da CLT, e 333, I, do CPC). Na hipótese vertente, o Tribunal Regional, valorando fatos e provas, firmou sua conviç̧ão de que a reclamante adotou todas as medidas necessárias para manter íntegro o vínculo de emprego. A reclamada, porém, não procedeu à readaptação em função compatível com as restrições decorrentes do seu estado de saúde, razão pela qual reconheceu a rescisão indireta e afastou a penalidade de abandono de emprego, tendo em vista a comunicação correspondente ter sido endereçada em data posterior à notificação expedida pela reclamante solicitando reintegração. Agravo a que se nega provimento.

(Ag-AIRR - 98100-74.2009.5.02.0072, Relator Ministro: Walmir Oliveira da Costa, Data de Julgamento: 04/02/2015, $1^{\text {a }}$ Turma, Data de Publicação: DEJT 06/02/2015)

\subsection{Empregados em situações especiais}

Raros são os estudos doutrinários sobre a suspensão do contrato de trabalho e seus respectivos efeitos em relação aos empregados que não preenchem os requisitos legais para percepção do auxílio-doença. 
O entrave da falta de sistematização científico-jurídica na análise da origem e efeitos da suspensão do contrato de trabalho, acaba por limitar a análise doutrinária na diferenciação entre suspensão contratual e interrupção contratual.

A partir disso, formaram-se dogmas que não permitem a reflexão aprofundada sobre o tema, que apresentam paradoxos não condizentes com uma sistematização jurídica.

A primeira questão que devemos reconhecer é que esses empregados, da mesma forma que os demais, quando incapacitados para o trabalho por motivo de doença, também cessam sua obrigação de fazer de prestar serviços ao empregador.

Independentemente da percepção do auxílio-doença, o fato é que foram acometidos de um fortuito exatamente como os demais empregados e não podem prestar serviços. $O$ efeitos jurídicos dessa impossibilidade estudaremos a seguir.

\subsubsection{Em período de carência e portador de doença anterior à filiação previdenciária}

O empregado que não contribuiu ao menos por doze meses (artigo 25, I, da Lei 8.213/91), observada a exceção do artigo 24, parágrafo único, da Lei 8.213/91), não recebe $\circ$ auxílio-doença previdenciário. $O$ auxílio-doença acidentário independe de carência.

O mesmo ocorre com o empregado portador de doença ou da lesão invocada como causa para o benefício, salvo quando a incapacidade sobrevier por motivo de progressão ou agravamento dessa doença ou lesão (artigo 59, parágrafo único da Lei $8.213 / 91$ ou artigo $60, \S 6^{\circ}$, após MP 664/2014). 
Como afirmado anteriormente, em que pese não preencherem os requisitos para percepção do benefício de auxílio-doença comum, cessa a prestação da obrigação de fazer consistente em prestar serviços em decorrência de fortuito.

A inegável autonomia da relação jurídica trabalhista em face da relação jurídica previdenciária (como anteriormente explanado e reconhecido pelo Supremo Tribunal Federal) explica o fundamento pelo qual é possível a aplicação de efeitos da suspensão contratual no âmbito trabalhista, independentemente do recebimento de benefício previdenciário.

Mais uma face dessa autonomia da relação jurídica, a Súmula 72 da Turma Nacional de Uniformização dos Juizados Especiais Federais estabelece que:

\footnotetext{
É possível o recebimento de benefício por incapacidade durante período em que houve exercício de atividade remunerada quando comprovado que o segurado estava incapaz para as atividades habituais na época em que trabalhou.
}

Não é o auxílio-doença, portanto, a causa originária da suspensão do contrato de trabalho e sim a ausência da obrigação de fazer consistente em prestar serviços em decorrência da incapacidade laborativa, justamente o que ocorre no tema em questão.

A principal consequência jurídica da suspensão contratual é a inaplicabilidade da cláusula resolutiva tácita e da exceção de contrato não cumprido, ambas inerentes aos contratos bilaterais, como anteriormente aventado.

Garante-se, portanto, seu retorno ao trabalho com todas as vantagens atribuídas à categoria (artigo 471 da CLT), bem como permanecem vigentes todas as demais cláusulas do contrato de trabalho para ambas as partes, salvo a 
obrigação de fazer de prestar serviços por parte do empregado, em razão do fortuito que lhe atingiu.

A única diferença, em nosso entender, é que o empregado nas situações em estudo não está licenciado sem remuneração (artigo 476 da CLT e artigo 63 da Lei 8.213/91), porquanto apenas reservada essa situação jurídica para aqueles que estão a receber auxílio-doença.

Como as cláusulas do contrato de trabalho permanecem vigentes e o empregado não está licenciado sem remuneração, a conclusão reveladora é de que compete ao empregador o pagamento de toda a remuneração a esses empregados durante o afastamento.

Acrescente-se que a garantia de subsistência mínima do trabalhador por seu empregador representa a aplicação direta do princípio da dignidade humana, do valor social do trabalho, da solidariedade e promoção do bem de todos, sem discriminação (artigos $1^{\circ}$, III e IV e artigo $3^{\circ}$, I e IV, da Constituição Federal).

Colaciona-se jurisprudência do Tribunal Superior do Trabalho nesse sentido:

AGRAVO DE INSTRUMENTO. RECURSO DE REVISTA -
DESCABIMENTO.
RESPONSABILIDADE PELO PAGAMENTO DA REMUNERAÇÃO
DURANTE O PERIODO DE AFASTAMENTO POR LICENÇA
MÉDICA. DECLARAÇÃO DO INSS DE INAPTIDÃO DA
TRABALHADORA PARA LABORAR. INDEFERIMENTO DO
BENEFÍCIO PREVIDENCIÁRIO. Interposto à deriva dos requisitos
traçados no art. 896, $9^{\circ}$, da CLT, não merece processamento o
recurso de revista. Agravo de instrumento conhecido e desprovido.
(AIRR - 2212-57.2012.5.14.0131, Relator Ministro: Alberto Luiz
Bresciani de Fontan Pereira, Data de Julgamento: 15/10/2014, $3^{\text {a }}$
Turma, Data de Publicação: DEJT 17/10/2014)

O teor do voto condutor desse acórdão é mais esclarecedor ao manter a decisão do Tribunal Regional, onde se encontra: 
Correto o entendimento da Juíza de $1^{\circ}$ grau no sentido da matéria ser resolvida à luz dos princípios de Direito do Trabalho, especificamente o princípio da alteridade, que se extrai do artigo $2^{\circ}$ da CLT.

Não se pode olvidar que é fundamento basilar da República Federativa do Brasil a dignidade da pessoa humana e os valores sociais do trabalho (art. $1^{\circ}$, incisos III e IV da CF). Ademais, a valorização do trabalho humano, sobre que é fundada a ordem econômica, tem o fim de assegurar a todos existência digna, conforme os ditames da justiça social (art. 170 da CF)

$\cdots$

E a trabalhadora não poderia ficar num limbo, pois o órgão previdenciário negou a concessão do benefício por questão de carência (não por força do problema de saúde) e, por seu turno, a empresa reconhece que a reclamante não estava em condições de trabalhar em qualquer setor da reclamada.

Pondera-se ainda que não há a quebra de sinalagma do contrato de trabalho, porquanto somente há o impedimento fortuito de uma delas: a prestação de serviços. As demais obrigações permanecem vigentes e o salário, como anteriormente analisado, decorre do contrato de trabalho (que permanece intacto) e não somente da prestação de serviços.

Trata-se, pois, de verdadeira licença remunerada por imperativo de norma cogente de ordem pública. Esse passa a ser o regime jurídico aplicável a esses afastamentos no contrato de trabalho, de modo que perderá as férias se o afastamento em licença remunerada for superior aos 30 (trinta) dias (artigo 133, II, da CLT); não receberá a gratificação natalina, por ausente a prestação de serviços (artigo $1^{\circ}$ da Lei 4.090/64); a remuneração estará sujeita aos depósitos de FGTS (artigo 15 da Lei 8.036/90); não poderá ser dispensado (artigo 471 da CLT); e receberá os demais direitos inerentes à suspensão contratual, conforme estudado anteriormente.

Como não poderia deixar de ocorrer, há entendimento em sentido contrário, pautado no fundamento de que a responsabilidade legal do empregador se limita ao pagamento dos primeiros 15 dias (ou 30 dias após a MP 664/2014), como previsto no artigo $60, \S 4^{\circ}$, da Lei $8.213 / 91$, bem como a ausência de culpa do empregador: 
CONTRATO DE TRABALHO - HIPÓTESE DE SUSPENSÃO CONTRATUAL - BENEFÍCIO PREVIDENCIÁRIO - PERÍODO DE CARÊNCIA INCOMPLETO. O indeferimento dos

requerimentos para concessão do benefício previdenciário por incapacidade ao trabalho foram indeferidos porque não completado o período de carência, hipótese que não decorreu de culpa da reclamada, vez que o contrato de trabalho vigorou por três meses, passando a incorrer, a partir do afastamento do autor por doença, em hipótese de suspensão contratual. A não percepção do benefício previdenciário não decorreu de culpa da ré, mas da falta das contribuições previdenciárias necessárias, não tendo sido completado o período de carência exigido pelo órgão previdenciário. Recurso ordinário a que se nega provimento. (RO 00934.2006.017.02.00-6, TRT 2a Região, Relatora Des. Mércia Tomazinho, Data de Julgamento: 17/02/2009, $3^{\text {a }}$ Turma, Data de Publicação: 03/03/2009 DOJT)

\subsubsection{Aposentado}

Aplica-se ao empregado aposentado o mesmo raciocínio do item anterior, com uma ressalva: a inacumulatividade com o auxílio-doença impede a percepção de salário pelo empregador ${ }^{210}$.

Estamos a defender que a suspensão contratual não congela, automaticamente, as cláusulas do contrato de trabalho, que permanecem em plena vigência, salvo a prestação de serviço por impedimento fortuito.

O recebimento do auxílio-doença afasta a necessidade de pagamento de salário pelo empregador, porque a lei estabelece o período como licença sem remuneração (artigo 476 da CLT e artigo 63 da Lei 8.213/91). Todavia, o empregado aposentado não pode receber o auxílio-doença em razão da não cumulação dos benefícios (artigo 124, l, da Lei 8.213/91).

No primeiro momento, nesse nosso raciocínio, poderia se crer que o empregador estaria obrigado a pagar a remuneração ao empregado aposentado. Mas não é essa a solução que propomos à espécie, em razão da interpretação sistemática e teleológica do artigo 476 da CLT.

\footnotetext{
${ }^{210}$ Por entendermos que o pagamento dos primeiros 15 dias (ou 30 após a MP 664/2014) se trata de abono de faltas (artigo 60, $\S 4^{\circ}$, da Lei 8.213/91) com o pagamento integral do respectivo salário (artigo $60, \S 3^{\circ}$, da Lei $8.213 / 91$ ), não há qualquer sentido excluir esse direito do empregado aposentado, ainda em razão da autonomia das relações jurídicas previdenciárias e trabalhistas, que produzem efeitos jurídicos independentes.
} 
Com efeito, o mencionado dispositivo legal tem a finalidade de estabelecer os efeitos da licença sem remuneração ao trabalhador que esteja assegurado da proteção previdenciária, garantindo-se sua subsistência mínima. A denominação do instituto não tem qualquer relevância. A propósito, a literalidade do dispositivo se refere a "seguro-saúde" ou "auxílio-enfermidade", benefícios substituídos pela denominação "auxílio-doença” na lei previdenciária.

Da mesma forma em que defendemos que a aposentadoria, sem a percepção do auxílio-doença, não impede estabilidade provisória do artigo 118 da Lei 8.213/91, diante da não cumulação desses benefícios, também se sujeita à incidência do artigo 476 da CLT, que prevê a licença sem remuneração quando o empregado já está abrangido pela proteção previdenciária, justamente porque são inacumuláveis.

Isso não impede o reconhecimento da incapacidade laborativa no contrato de trabalho, tal qual estudada anteriormente, bem como os mesmos efeitos da suspensão contratual atinentes aos empregados não aposentados.

Essa conclusão reafirma a autonomia da relação jurídica trabalhista em face da relação jurídica previdenciária.

\subsection{A alta previdenciária do empregado incapacitado para o trabalho}

Limbo, na acepção da língua portuguesa é, em sentido figurativo, o "estado de indecisão ou esquecimento" ${ }^{211}$.

Não há dúvidas de que a expressão veste como uma luva para ilustrar a situação em que o empregado recebe a alta previdenciária, mas ainda incapacitado para o trabalho. Isso porque não recebe benefício previdenciário e

$\overline{{ }^{211} \text { HOUAISS, op. cit., 2001, p. } 1758 .}$ 
também não recebe salário (afinal, não retorna ao trabalho), vivendo em estado de indecisão ou esquecimento.

Há tempos existe essa situação no Direito Brasileiro, derivada principalmente do "risco moral" na sociedade brasileira. Todavia, a partir de 2005, ganhou notoriedade após a instituição da alta programada, o retorno precoce ao trabalho e a fúria de restrição orçamentária da Previdência Social (remetemos o leitor ao capítulo 3 a respeito de todos esses pontos).

O sistema da alta programada não se coaduna com a sistemática trabalhista prevista nos item 7.4.1 e 7.4.3.3 da Norma Regulamentadora $n^{0} 7$ Programa de Controle Médico de Saúde Ocupacional, aprovada pela Portaria GM $n^{\circ} 3.214$, de 08 de junho de 1978, de observância obrigatória pelo empregador (artigo 157, I, da CLT):

7.4.1 O PCMSO deve incluir, entre outros, a realização obrigatória dos exames médicos:

c) de retorno ao trabalho;

$\ldots$

7.4.3.3 No exame médico de retorno ao trabalho, deverá ser realizada obrigatoriamente no primeiro dia da volta ao trabalho de trabalhador ausente por período igual ou superior a 30 (trinta) dias por motivo de doença ou acidente, de natureza ocupacional ou não, ou parto.

7.4.4 Para cada exame médico realizado, previsto no item 7.4.1, o médico emitirá o Atestado de Saúde Ocupacional - ASO, em 2 (duas) vias.

7.4.4.3 O ASO deverá conter no mínimo:

e) definição de apto ou inapto para a função específica que o trabalhador vai exercer, exerce ou exerceu; $\ldots$

Isso porque não existe nova perícia da Previdência Social que ateste a capacidade laborativa, salvo, a contrario sensu, quando indeferido o pedido de prorrogação ou reconsideração requerido pelo segurado, por não constatada a incapacidade laborativa (caso em que o perito-médico-previdenciário entende pela alta médica do empregado). 
Por outro lado, o médico do trabalho necessita realizar a avaliação do empregado e fornecer o atestado de saúde ocupacional (ASO) com a definição de aptidão para retorno o trabalho, antes que ele ocorra.

Cláudia Salles Vilela Vianna entende que:

\begin{abstract}
... tendo o trabalhador apresentado à empresa (ou médico do trabalho, no início do exame de retorno) um atestado médico indicando a permanência da incapacidade laborativa, não é possível o seu retorno ao trabalho, ainda que o mesmo não esteja percebendo o benefício previdenciário. Não haverá o primeiro dia de volta ao trabalho, justamente porque o empregado apresentou um documento que impede tal ocorrência, mesmo tendo a Previdência Social cancelado seu benefício de auxílio-doença.

...

Nessa linha de raciocínio, no momento em que o empregado apresenta um atestado médico indicando a permanência da incapacidade, manifesta expressamente que não retornará ao trabalho, não se justificando, pois, a realização do exame médico do retorno. ${ }^{212}$
\end{abstract}

Data venia, isso não é possível. Diante da alta previdenciária do INSS, necessário que o empregado se apresente perante o empregador para justificar que não retornará ao trabalho.

Não basta apresentar um atestado médico de incapacidade para desconstituir a presunção de veracidade inerente ao ato administrativo da autarquia previdenciária. Precisa se submeter à análise clínica do médico do trabalho, tal como exigida na norma trabalhista, a fim de que seja constatada a real existência de incapacidade laborativa do empregado.

Há situações em que o empregado sequer teve acesso à rede pública de saúde e não porta atestado médico, mas entende que permanece portador de incapacidade laborativa. $\mathrm{O}$ exame de retorno ao trabalho é indiscutível.

A expressão "primeiro dia da volta ao trabalho" corresponde, em nosso ver, ao primeiro dia em que o empregado volta ao seu local de trabalho após a ${ }_{212}$ VIANNA, Cláudia Salles Vilela, op. cit., 2010, p. 110 e 111. 
alta previdenciária. Outrossim, não será o momento do ASO que definirá os efeitos no contrato de trabalho, sob pena de se criar situação meramente potestativa (o empregador simplesmente se furtará de realizar o exame de retorno ao trabalho).

O médico do trabalho responsável pelo exame de saúde ocupacional parece estar em melhor condições de atestar sobre a saúde do empregado, porque: a) tem maior conhecimento das condições de trabalho no empregador (recorde-se a acepção de incapacidade contextualizada no ambiente de trabalho); b) não realiza atendimento massificado inerente à autarquia previdenciária; e c) não está sujeito às concepções administrativas para a decisão de concessão do benefício previdenciário ${ }^{213}$.

Não é de se espantar, portanto, a usual divergência das conclusões do médico-perito-previdenciário e do médico do trabalho. Registre-se que a questão certamente ganhará novo rumo com a edição da MP 664/2014, que possibilitou a realização de convênio com as empresas para a realização de perícia médica ${ }^{214}$ na medida em que o mesmo médico realizaria tanto a perícia previdenciária como o atestado de saúde ocupacional.

\begin{abstract}
Em relação ao empregado, temporário e avulso, crê-se que o ideal seria o propiciador do seu trabalho quem deva emitir os laudos técnicos. Até porque o médico do trabalho da empresa tem maior conhecimento do prontuário clínico do trabalhador.
\end{abstract}

\footnotetext{
${ }^{213}$ Não há documento ou declaração oficial de que esse último item ocorra na previdência social. Sabe-se que a uniformização dos procedimentos e prazos de concessão de benefício de incapacidade em razão de determinada doença (conforme Manuais de Perícia aprovados pelo INSS) retira a autonomia técnica para o estabelecimento da incapacidade, a qual sequer é contextualizada no ambiente de trabalho do empregado, por ausência de vistoria no local. As perícias médicas na previdência social também são realizadas em poucos minutos, com o perito perdendo mais tempo em preencher documentos burocráticos (entre eles, o laudo médico) do que analisando a incapacidade do segurado. Finalmente, o dissenso técnico aos procedimentos e prazos previstos nos Manuais de Perícia Médica retira o médico-perito-previdenciário da média de seus pares, acabando por expô-lo às possíveis responsabilidades administrativas, além de se sujeitar à desconfiança no seu ambiente de trabalho. Por fim, cabe lembar que a alta precoce é concepção difundida nos Manuais de Perícia Médica da previdência social.

${ }^{214}$ A Associação Nacional dos Médicos Peritos (ANMP) realiza atos para evitar a "terceirização da perícia médica previdenciária". Em manifestação, presidente da ANMP repudia MP 664 que abre brechas para a terceirização da perícia médica previdenciária. Artigo sem data. Disponível em: <http://www2.anmp.org.br/?p=1442>; acesso em 05 dez 2014.
} 
Uma avaliação sistemática das distonias entre os resultados dos dois exames deve ser objeto de regulamentação para evitar que essa solução seja desmoralizada. ${ }^{215}$

Compreendida a situação macro em que o trabalhador/segurado está inserido, necessária a análise de seus efeitos jurídicos em escala individual.

O primeiro ponto que o empregado deve se atentar é a necessidade de comunicação ao empregador da cessação do benefício previdenciário e de que não está apto para retorno ao trabalho, submetendo-se ao exame médico de retorno ao trabalho. Trata-se do princípio da boa-fé objetiva, anteriormente estudado, bem como a justificativa de ausência de retorno ao trabalho.

Hodiernamente, não raro, o empregado simplesmente desaparece após a cessação do benefício previdenciário (fato nem sempre de conhecimento do empregador), sem dar qualquer notícia.

Por essa razão, o Tribunal Superior do Trabalho sintetizou a questão na antiga Súmula 32:

32 - Abandono de emprego (RA 57/1970, DO-GB 27.11.1970. Nova redação - Res. 121/2003, DJ 19.11.2003)

Presume-se 0 abandono de emprego se $o$ trabalhador não retornar ao serviço no prazo de 30 (trinta) dias após a cessação do benefício previdenciário nem justificar o motivo de não o fazer.

O prazo de 30 (trinta) dias surgiu de aplicação análoga do disposto no artigo $472, \S 1^{\circ}$, da CLT.

Qualquer recebimento que o empregado obtenha do empregador nesse período de ausência injustificada, deverá ser ressarcida ao empregador, por significar enriquecimento sem causa do empregado:

${ }^{215}$ MARTINEZ, Wladimir Novaes. Curso de Direito Previdenciário. 3. ed. São Paulo: LTr, 2014, p. 856. 
DESCONTO DE BENEFÍCIO PREVIDENCIÁRIO RECEBIDO PELO RECLAMANTE DIRETAMENTE DA RECLAMADA. Considerando-se o final do período de gozo de benefício previdenciário, incumbia ao Reclamante, ao final da alta médica, buscar a prorrogação da percepção de benefício previdenciário ou retornar imediatamente ao serviço. Ao não retornar ao serviço, com o fim do direito ao benefício previdenciário, o Autor recebeu os valores pagos pela Reclamada indevidamente, o que caracteriza enriquecimento sem causa previsto no art. 884 do Código Civil. Recurso de revista de que se conhece e a que se dá provimento.

(Ementa parcial - RR - 300-13.2007.5.17.0003, Relator Ministro: Fernando Eizo Ono, Data de Julgamento: 01/10/2014, $4^{\text {a }}$ Turma, Data de Publicação: DEJT 10/10/2014)

Não há que se confundir essa situação (desaparecimento voluntário do empregado) com a postura pró-ativa do empregado em comunicar o motivo de não retorno ao trabalho (por exemplo, por interposição de recurso administrativo ou ação judicial em face da negativa do benefício previdenciário).

A atitude pró-ativa do empregado afasta o animus abandonandi, porquanto não há o elemento subjetivo (intenção) de abandono de emprego. Há, em verdade, objetivo claro de se opor às decisões da autarquia previdenciária por se entender incapacitado para o trabalho, não prevalecendo a justa causa:

AGRAVO DE INSTRUMENTO EM RECURSO DE REVISTA DISPENSA POR JUSTA CAUSA - AUSÊNCIA DE RETORNO AO SERVIÇO APÓS A CESSÃO DE BENEFÍCIO PREVIDENCIÁRIO CONDUTA JUSTIFICADA PELO ESTADO DE SAÚDE DO RECLAMANTE E COMPROVADA POR ATESTADOS MÉDICOS REVERSÃO DA PENALIDADE. O Tribunal, assim como o juízo de primeiro grau, reportou-se à prova documental produzida nos autos para concluir que o reclamante não retornou ao serviço após a alta previdenciária em razão do seu estado de saúde, o que foi devidamente comprovado nos autos, a teor dos atestados médicos apresentados à reclamada. Nesse quadro, impertinente a invocação dos arts. 818 da CLT e 333 do CPC, que cuidam da distribuição processual do ônus da prova, uma vez que as regras de distribuição do ônus probatório somente têm lugar quando, em face de ausência de prova ou de prova inconclusiva, o julgador é instado a decidir desfavoravelmente à parte a quem entende competir o ônus de provar. Essa não é a situação dos autos, uma vez que a Corte a quo se ampara na prova documental produzida nos autos e conclusiva a respeito dos pontos controvertidos para decidir a lide em desfavor da reclamada. A decisão regional não diverge, e, sim, mostra-se em consonância com a Súmula $n^{\circ} 32$ do TST, que presume o abandono de emprego se o trabalhador não retorna ao serviço trinta dias após a cessação do benefício previdenciário, nem justifica o motivo de não o fazer. No caso, o reclamante justificou o fato de não ter retornado, mediante apresentação de atestados médicos. Agravo de instrumento 
desprovido. ( AIRR - 6900-71.2008.5.05.0028, Relator Ministro: Luiz Philippe Vieira de Mello Filho, Data de Julgamento: 29/10/2014, $7^{\text {a }}$ Turma, Data de Publicação: DEJT 07/11/2014).

Está-se a tratar, pois, da incompatibilidade entre a decisão da previdência social (alta médica) e a incapacidade laborativa reconhecida pelo empregado (quando não seu próprio médico) e seu empregador (por meio de seu médico do trabalho).

A consonância da alta previdenciária com a aptidão atestada pelo médico do trabalho implica na obrigatoriedade de retorno do empregado ao trabalho, o que somente poderá ser desconstituía por decisão administrativa do INSS ou judicial em sentido contrário.

Ressalte-se, novamente, que essas situações demonstram que a suspensão da obrigação de fazer de prestar serviços em razão de incapacidade laborativa origina a suspensão do contrato de trabalho, independentemente do recebimento do auxílio-doença.

Observe-se que o elemento configurador da suspensão contratual não é propriamente o benefício pago pelo INSS, mas sim o documento médico que indique necessidade de afastamento das atividades profissionais por razão de acidente ou doença. Mesmo que o segurado não busque a percepção do benefício, seu contrato de trabalho deverá permanecer suspenso, até que apresente documento de alta ou de termine o eventual prazo fixado no primeiro atestado apresentado ao empregador. ${ }^{216}$

A melhor solução diante dessa situação, se possível, é alterar a função do empregado compatível com seu estado de saúde:

Nesse contexto, considerando que o trabalhador não tem condições
de retornar ao mesmo posto de trabalho, deve o Médico do Trabalho
entrar em contato com o empregador desse trabalhador e orientar
que o retorno do trabalho pode provocar agravamento de algum
problema de saúde, indicando uma nova função ao trabalhador.
Possivelmente, o empregador irá recusar a solicitação médica, então,
deve indicar ao empregador que mantendo essa conduta nefasta
poderá ser responsabilizado civilmente, por provocar danos ao
trabalhador, embasado nos arts. 186 e 927 do Código Civil, e

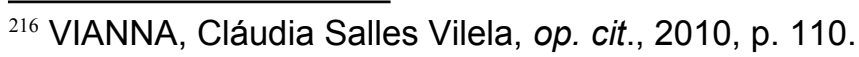


também ser responsabilizado criminalmente, com fulcro no art. 132 do Código Penal, que tipifica o crime de expor a vida ou a saúde de outrem a perigo; mantendo tudo registrado no prontuário individualizado do paciente, para demonstrar em futuras lides judiciais a boa intenção e zelo com o trabalhador. ${ }^{217}$

A incompatibilidade da incapacidade laborativa do empregado com qualquer outra atividade que possa desempenhar na empresa acarretará a responsabilidade por pagamento de salários por seu empregador, o que veremos a seguir.

\subsubsection{Responsabilidade da previdência social e do empregador}

Posta a questão em voga, cabe perquirir sobre os efeitos do limbo em relação ao empregado sem benefício previdenciário.

Invoca-se, novamente, o raciocínio de que o contrato de trabalho permanece com todas suas cláusulas vigentes, salvo a obrigação de fazer consistente em prestar serviços, diante do fortuito em que se encontra o empregado.

Com a cessação do benefício previdenciário, não mais se pode considerar o empregado em licença sem remuneração (efeito do artigo 476 da CLT e artigo 63 da Lei 8.213/91), requisito indispensável para tanto.

Permanece a suspensão da obrigação de fazer consistente em prestar serviços por parte do empregado, mas a norma jurídica que afasta do pagamento da remuneração não passa a ser aplicada.

217 SOARES, Saulo Cerqueira de Aguiar; SOARES, Ivna Maria Mello. Limbo trabalhistaprevidenciário: médico do trabalho e médico do INSS. - reflexões médicas, éticas e jurídicas acerca dos aspectos polêmicos. Instituto de Estudos Previdenciários, Belo Horizonte, ano 08, $n^{\circ}$. 313, 09 junho 2014. Disponível em:

<http://www.ieprev.com.br/conteudo/id/34721/t/limbo-trabalhista-previdenciario:-medicodo-trabalho-e-medico-do-inss:---reflexoes-medicas,-eticas-e-juridicas-acerca-dos-aspectospolemicos>; acesso em $15 \mathrm{dez} 2014$. 
A evidente finalidade do artigo 476 da CLT é estabelecer que o empregador não será obrigado a pagar remuneração ao empregado sob proteção previdenciária, porque em licença não remunerada.

Desaparecida a licença não remunerada, o contrato de trabalho passa a viger em sua integralidade, não podendo o empregador se negar ao pagamento salarial (mais uma vez, recorde-se que o sinalagma se refere ao contrato de trabalho como um todo e não prestação por prestação).

Nesse sentido, mas entendendo não mais subsistir suspensão contratual, o Tribunal Superior do Trabalho:

\begin{abstract}
DANOS MATERIAIS E MORAIS - BENEFÍCIO PREVIDENCIÁRIO NEGADO AO EMPREGADO - INAPTIDÃO PARA O TRABALHO RESPONSABILIDADE DO EMPREGADOR PELO PAGAMENTO DOS SALÁRIOS

Após a alta previdenciária, e consequente fim do período de suspensão do contrato de trabalho, a regra impositiva de pagamento de salários volta a ter eficácia, ainda que a empresa, contrariando as conclusões da Previdência Social, considere o empregado inapto ao trabalho. Com efeito, deve o empregador responder pelo pagamento dos salários devidos no período em que o empregado esteve à disposição da empresa (art. $4^{\circ}$ da CLT), sobretudo diante do seu comparecimento para retorno ao trabalho.

Estão configurados os elementos que ensejam o dever de reparação, nos termos da teoria da responsabilidade subjetiva: o dano moral (sofrimento psicológico decorrente da privação total de rendimentos por longo período), o nexo de causalidade (dano relacionado com a eficácia do contrato de trabalho) e a culpa (omissão patronal no tocante ao pagamento dos salários) (RR-142900-28.2010.5.17.0011. Relator Desembargador Convocado João Pedro Silvestrin, $8^{\text {a }}$ Turma, j. 20/11/2013, DEJT 22/11/2013).
\end{abstract}

Outros precedentes jurisprudenciais acrescentam novos fundamentos a essa responsabilidade para o empregador: a) a presunção de legitimidade da perícia médica do INSS; e b) garantir a subsistência do trabalhador diante do princípio da dignidade humana e valor social do trabalho.

Nesse sentido, precedente do Tribunal Superior do Trabalho: 
TRABALHO. APTIDÃO RECONHECIDA PELO INSS E NEGADA POR MÉDICO DA EMPRESA. EFEITOS DO CONTRATO DE TRABALHO. Ocorrendo divergência entre a conclusão da perícia previdenciária e o atestado médico da empresa, competia ao reclamado diligenciar junto ao INSS solução para o deslinde da questão ou até mesmo realocar o empregador em setor diverso daquele que antes laborava, enquanto não houvesse reforma da decisão administrativa. Não se pode atribuir ao obreiro o ônus de suportar os prejuízos decorrentes do impasse entre as decisões, ficando desemparado sem percepção de nenhum meio de subsistência. Assim, comprovada a tentativa do obreiro de retorno ao trabalho, tendo sido negada pelo reclamado, incumbe a este a responsabilidade pelo pagamento dos salários e demais verbas compreendidas a partir da cessação do auxílio-doença. Inocorrência de violação aos dispositivos legais e constitucionais a ensejar o processamento da revista com supedâneo no art. 896, -C-, da CLT. Agravo de instrumento desprovido.

( AIRR - 753-72.2012.5.04.0333, Relator Ministro: Arnaldo Boson Paes, Data de Julgamento: 20/08/2014, $7^{\text {a }}$ Turma, Data de Publicação: DEJT 22/08/2014)

\section{Onde se encontra no teor do voto condutor do acórdão:}

Não se pode atribuir ao obreiro o ônus de suportar os prejuízos decorrentes do impasse entre as decisões, ficando desemparado sem percepção de nenhum meio de subsistência. Tal solução não se coaduna com os princípios constitucionais da dignidade da pessoa humana e do valor social do trabalho (art. $1^{\circ}$, III e IV, da CF). Ademais, a perícia médica do INSS possui caráter público da presunção de legitimidade, podendo ser elidida por robusta prova em contrário, não ocorrendo quando a inaptidão é comprovada apenas por atestados médicos particulares.

Desta feita, comprovada a tentativa da reclamante de retorno ao trabalho bem como da recusa do reclamado, compete a este a responsabilidade pelo pagamento dos salários e demais verbas compreendidas a partir da cessação do auxílio-doença.

Na medida em que impõe ao empregador o pagamento de salários sem a correspondente prestação de serviços, há entendimento de que se quebra o sinalagma do contrato de trabalho:

O contrato de trabalho é do tipo sinalagmático e bilateral; as obrigações, portanto, renovam-se diariamente: a do empregado, em prestar os serviços contratados e, do empregador, em efetuar o pagamento da contraprestação. Obrigar que a empresa remunere o trabalhador sem poder-lhe exigir a prestação de serviços, é uma situação que pode ser reconhecida como elemento de quebra deste caráter essencial do pacto empregatício. ${ }^{218}$

218 TREVISO, Marco Aurélio Marsiglia. A competência da Justiça do Trabalho, a incapacidade laborativa do trabalhador e os benefícios previdenciários. São Paulo: Ltr, 2012, p. 82. 
Como estamos a defender, a suspensão da obrigação de fazer consistente em prestar serviços, na hipótese, decorre de caso fortuito. Nessa situação, os contratos bilaterais ou sinalagmáticos, no Direito Civil, extinguem-se em razão da cláusula resolutiva tácita (artigo 475 do Código Civil) e impedem o cumprimento da obrigação pela parte contrária, pela exceção de contrato não cumprido (artigo 476 do Código Civil).

Esse sistema foi aplicado por muito tempo para o trabalho humano subordinado. Com o passar dos anos, o caráter tuitivo do Direito do Trabalho criou a figura da suspensão contratual para afastar a cláusula resolutiva tácita (com o impedimento da extinção contratual - artigo 471 da CLT) e impedir a aplicação da exceção de contrato não cumprido (ao determinar obrigações por parte do empregador durante a suspensão da prestação de serviços, como anteriormente estudado).

Compreendido que o salário é a contraprestação do contrato de trabalho como um todo e não somente da obrigação de fazer, a cessação do benefício previdenciário afasta a licença não remunerada prevista no artigo 476 da CLT, por desaparecimento do requisito nele previsto. Inexistindo congelamento da cláusula contratual, o pagamento de salário passa a ser consequência natural à situação em comento, garantindo-se a subsistência do trabalhador.

Por conseguinte, não há quebra no sinalagma do contrato de trabalho.

Em sentido contrário, há o fundamento de que não compete ao empregador o pagamento superiores aos primeiros 15 dias (ou 30 dias após a MP 664/2014):

Na hipótese de o INSS ter procedido ao cancelamento do benefício de auxílio-doença, é de interesse do segurado empregado a discussão administrativa ou judicial da alta praticada, visto que não constitui obrigação da empresa o pagamento da remuneração

\footnotetext{
A situação é tão intrigante que o autor aponta fundamentos jurídicos para justificar a competência da Justiça do Trabalho no julgamento de demandas em face do empregador e do INSS para solucionar a questão.
} 
correspondente aos dias de afastamentos excedentes da primeira quinzena.

Caso o trabalhador seja vencedor na ação correspondente, caberá ao INSS o pagamento dos dias vencidos a contar da alta praticada, devendo referida autarquia reabrir o benefício que fora ilegalmente cancelado... Caso o trabalhador não seja vencedor, e se comprove que a incapacidade laborativa havia sido, de fato, recuperada, não terá o trabalhador direito à percepção dos salários correspondentes, devendo retornar às atividades profissionais sem a apresentação de atestado de incapacidade... ${ }^{219}$

AUXÍLIO-DOENÇA. INCAPACIDADE LABORATIVA E ALTA MÉDICA IRREGULAR. RESPONSABILIDADE PREVIDENCIÁRIA

1. No caso de incapacidade laborativa a responsabilidade da empresa fica limitada ao pagamento dos primeiros quinze dias de afastamento, competindo ao órgão previdenciário pagar o auxíliodoença pelo restante do tempo que perdurar a incapacidade. 2. Se o órgão previdenciário, de forma equivocada, liberou o trabalhador para retorno ao trabalho e esse, por incapacidade laborativa, não conseguiu fazê-lo, permanece a situação suspensiva do contrato, não tendo o empregador obrigação de pagar salários no período de inatividade. 3. Comprovada que a situação incapacitante sobreviveu à alta médica, competirá ao INSS realizar o pagamento do auxíliodoença, pois o empregador não é responsável pela irregularidade. 4 . Recurso não provido. 5. Decisão unânime.

(TRT 24a Região, TP, ROPS - 1035-2005-002-24-00, 12/01/2006 DOMS, Relator Amaury Rodrigues Pinto Junior $)^{220}$

Em que pese competir à Previdência Social cobrir os eventos de doença (artigo 201, I, da CF) após o $16^{\circ}$ dia (ou $31^{\circ}$ após a MP 664/2014), não se pode olvidar que as relações jurídicas previdenciárias e trabalhistas são autônomas, produzindo seus efeitos próprios. Por essa razão, o indeferimento do benefício de auxílio-doença não implica, necessariamente, na ausência de responsabilidade trabalhista do empregador, o que demonstramos anteriormente.

Por fim, existe determinada situação em que se apresenta indiscutível a obrigatoriedade de pagamento dos salários: a incapacidade laborativa causada por culpa do empregador.

Isso ocorre porque o artigo 120 da Lei 8.213/91 dispõe que:

Art.120. Nos casos de negligência quanto às normas padrão de segurança e higiene do trabalho indicados para a proteção individual

${ }_{220}^{219}$ VIANNA, Cláudia Salles Vilela, op. cit., 2010, p. 111.

${ }^{220}$ Ibidem, p. 112. 
e coletiva, a Previdência Social proporá ação regressiva contra os responsáveis.

Nessas hipóteses de afastamento, em última análise, será o próprio empregador que deverá ressarcir a previdência social pelas despesas causadas por sua negligência 221 .

Destarte, reconhecida a incapacidade do trabalhador acidentado por culpa do empregador, a responsabilidade de pagamento dos salário pelo empregador apenas afasta a figura intermediária do INSS.

\subsubsection{Efeitos da concessão retroativa de auxílio-doença e a implantação retroativa por ordem judicial}

Estudamos anteriormente os efeitos da dispensa sem justa causa durante a suspensão do contrato de trabalho, que acarreta na nulidade do ato e respectivo restabelecimento das partes ao estado anterior, por meio da reintegração.

A ausência de reconhecimento da incapacidade laborativa do trabalhador pela alta programada ou indeferimento do pedido de prorrogação/reconsideração, associada à aptidão atestada pelo médico do trabalho ${ }^{222}$, pode ser afastada por provimento a recurso administrativo na seara previdenciária, ou então, por implantação do benefício previdenciário por ordem judicial.

\footnotetext{
${ }^{221}$ A respeito das ações regressivas, cabe ressaltar que o Tribunal Superior do Trabalho recomendou que os juízes do trabalho enviem as cópias das sentenças condenatórias em ações sobre acidente de trabalho à Procuradoria Geral Federal para o exercício do direito regressivo. Sobre esta recomendação, seguida pelos juízes, destacou o procurador federal Fernando Maciel que "aumentou expressivamente o número de ajuizamento de ações sobre o tema. Em 2001, apenas 14 ações nesse sentido foram ingressadas. Após o convênio, mais de 500 já foram ajuizadas" in Revista Ltr. Ano $78-\mathrm{n}^{\circ} 4$ - abril/2014. p. 390.

${ }_{222}$ Há doutrina especializada que apresenta a seguinte sugestão de conduta ao médico do trabalho: "submissão à decisão do INSS, por estrito cumprimento de dever legal ou no exercício regular de direito, a qual reconheceu a aptidão do empregado para o retorno ao trabalho". Vide: SOARES; SOARES, op.cit., 2014.
} 
A situação fática se agrava quando esse reconhecimento retroativo da incapacidade laborativa advém posteriormente à dispensa sem justa causa.

Inicialmente, cabe verificar a extensão temporal de reconhecimento da incapacidade: a) retroativa ao requerimento administrativo; e b) retroativa ao laudo pericial judicial.

O reconhecimento da incapacidade laborativa retroativa, com a respectiva percepção de auxílio-doença, implica na incidência do artigo 476 da CLT e 63 da Lei 8.213/91, que estabelecem que o empregado permanece em licença sem remuneração. Por isso, a dispensa sem justa causa ocorrida é nula de pleno direito, ocorrendo o restabelecimento do estado anterior com a reintegração do empregado (recorde-se que, no plano fático, o retorno ao trabalho não ocorrerá caso a suspensão contratual persista).

Nesse sentido, jurisprudência do Tribunal Superior do Trabalho:

REINTEGRAÇÃO. SUSPENSÃO DO CONTRATO DE TRABALHO. PERCEBIMENTTO DE AUXÍLIO-DOENÇA. ALTA PELO INSS EM DATA ANTERIOR AO DESPEDIMENTO. RECURSO ADMINISTRATIVO DO EMPREGADO PERANTE O ÓRGÃO PREVIDENCIÁRIO. RECONHECIMENTO DA EXISTÊNCIA DE INCAPACIDADE DESDE DATA ANTERIOR À DISPENSA. EFEITOS. O Regional manteve o deferimento da reintegração do reclamante por entender que, malgrado o empregado, quando fora dispensado em $3 / 5 / 2007$, encontrava-se aparentemente apto para o trabalho, tendo em vista que fora liberado pelo INSS em 20/4/2007 após receber auxílio-doença por mais de quinze dias, o certo é que, em virtude de recurso interposto junto ao órgão previdenciário, foi reconhecida a incapacidade do autor para o trabalho desde $26 / 8 / 2006$, data anterior à dispensa, situação ainda vigente à época daquela decisão colegiada, pelo que reconheceu a suspensão do contrato de trabalho. Dessa forma, tendo o Regional se louvado explicitamente na norma do artigo 476 da CLT para reconhecer a nulidade da dispensa do reclamante, não há como se divisar dessa decisão, que não reconhecera se tratar de caso de ato jurídico perfeito, afronta direta ao artigo $5^{\circ}$, inciso $X X X V I$, da Constituição Federal. No mais, tendo o Regional reconhecido o direito à reintegração por divisar suspensão do contrato de trabalho em virtude de percepção de auxílio-doença não decorrente de acidente de trabalho, revela-se impertinente a invocação da Súmula $n^{\circ} 378$ do TST, que preconiza os pressupostos para o reconhecimento da estabilidade provisória decorrente de acidente do trabalho. Por fim, a invocação genérica de violação do artigo $5^{\circ}$, inciso II, da Constituição 
Federal de 1988, em regra e como ocorre neste caso, não é suficiente para autorizar o conhecimento deste recurso com base na previsão da alínea -C- do artigo 896 da CLT, na medida em que, para sua constatação, seria necessário concluir, previamente, ter havido ofensa a preceito infraconstitucional. Recurso de revista não conhecido.

(Ementa parcial - RR - 285900-55.2008.5.09.0019, Relator Ministro: José Roberto Freire Pimenta, Data de Julgamento: 17/12/2014, $2^{\mathrm{a}}$ Turma, Data de Publicação: DEJT 30/01/2015)

\section{Entretanto, há entendimento em sentido contrário, sob o argumento de}

que, no momento da dispensa, não havia qualquer óbice à extinção contratual.

Colaciona-se jurisprudência ilustrativa a respeito:

AUXÍLIO-DOENÇA PREVIDENCIÁRIO. ALTA MÉDICA. DISPENSA IMOTIVADA. VALIDADE. O cerne dos presentes autos repousa em se definir a legalidade da dispensa do autor em face dos afastamentos previdenciários, principalmente em eventual feito retroativo que a ação movida contra o INSS teria no contrato de trabalho, gerando por consequência a suspensão do contrato de trabalho. Consta dos autos que o autor teve alta médica de um benefício previdenciário em 31 de outubro de 2007. O autor moveu ação em face do INSS pleiteando o restabelecimento do benefício, sendo que esta decisão determinou o restabelecimento do benefício desde 01/11/2007. Com efeito, consoante se depreende da vasta documentação colacionada aos autos é incontroverso que o autor teve cessado seu benefício previdenciário em 31/10/2007, retornando ao trabalho e sendo dispensado em 18/03/2008 e somente obtendo o restabelecimento do auxílio doença em 20/10/2008, com efeito retroativo a partir de 01/11/2007. Fica claro, portanto, que no momento em que se consumou a rescisão contratual do autor não havia qualquer óbice para a dispensa, posto que naquele momento o contrato de trabalho não mais estava mais suspenso, como preceitua o artigo 476 da CLT. Entendo que não existe amparo legal para que o restabelecimento do benefício tenha efeitos retroativos à data da alta médica anterior. Tem-se, na realidade, um novo auxílio-doença a partir da data da perícia, hipótese que, aplicada aos presentes autos, revela que no período, saliente-se, superior a sessenta dias, compreendido entre 31/10/2007 (cessação do primeiro benefício) e 08/08/2008 (data da prolação da sentença que deferiu o restabelecimento), o contrato de trabalho não se encontrava suspenso. Diante desses fundamentos, não há que se cogitar da ilegalidade da dispensa, destacando-se que a doença do autor não implica em qualquer tipo de garantia no emprego. qualquer tipo de garantia no emprego).

(RO 00274004420095020211, TRT $2^{\mathrm{a}}$ Região, 12a Turma, Relator: Francisco Ferreira Jorge Neto, Julgamento: 30/06/2011, Publicação: 08/07/2011).

Esse posicionamento não nos parece adequado. O artigo 60, II, da Lei 
Art. 60. O auxílio-doença será devido ao segurado que ficar incapacitado para seu trabalho ou sua atividade habitual, desde que cumprido, quando for o caso, o período de carência exigido nesta Lei: I - ao segurado empregado, a partir do trigésimo primeiro dia do afastamento da atividade ou a partir da data de entrada do requerimento, se entre o afastamento e a data de entrada do requerimento decorrerem mais de quarenta e cinco dias;

II - aos demais segurados, a partir do início da incapacidade ou da data de entrada do requerimento, se entre essas datas decorrerem mais de trinta dias.

A norma previdenciária é clara ao fixar a data do início do benefício de auxílio-doença (para o empregado, a partir do $31^{\circ}$ dia do afastamento ou do requerimento administrativo, se formulado após 45 dias do afastamento; para os demais segurados, como o empregado doméstico a partir da incapacidade).

Essa data de início do benefício não é postergada em razão de eventual provimento de recurso administrativo que reconheça a incapacidade laborativa desde então.

Da mesma forma, a sentença judicial condenatória produz efeitos retroativos à data do descumprimento da obrigação jurídica previdenciária, conforme fixada nesse dispositivo legal, ressalvado quando a incapacidade somente passou a ser reconhecida a partir do laudo pericial no processo judicial previdenciário:

RECURSO DE REVISTA. 1. DISPENSA POR JUSTA CAUSA. ABANDONO DE EMPREGO. EMPREGADA DOENTE. BENEFÍCIO PREVIDENCIÁRIO RETROATIVO. CONTRATO DE TRABALHO SUSPENSO. REVERSÃO EM JUIIZO. 2. DANOS MORAIS. COISA JULGADA. INEXISTÊNCIA. 3. HORAS EXTRAS. APELO DESFUNDAMENTADO. 4. INDENIZAÇÃO PELO USO DE VEÍCULO PRÓPRIO. SÚMULA 126/TST. 5. ASSÉDIO MORAL. RESPONSABILIDADE CIVIL. DANOS MORAIS. 6. DANOS MORAIS. DANO DECORRENTE DO PRÓPRIO FATO. DISPENSÁVEL A COMPROVAÇÃO DE PREJUÍZO CONCRETO. 7. DANOS MORAIS. VALOR DA INDENIZAÇÃO. 8. HORAS EXTRAS DECORRENTES DA SUPRESSÃO DO INTERVALO DO ART. 384 DA CLT. Inviável a admissibilidade do recurso de revista, se não preenchidos os requisitos do art. 896 da CLT. Recurso de revista não conhecido, nos temas.

(Ementa parcial - RR - 606-91.2012.5.04.0512, Relator Ministro: Mauricio Godinho Delgado, Data de Julgamento: 26/11/2014, $3^{\text {a }}$ Turma, Data de Publicação: DEJT 28/11/2014). 
O relator do acórdão acima se reportou e utilizou como fundamento o voto do acórdão regional, em que se encontra:

\begin{abstract}
Em que pese o teor da Súmula 32 do TST ("Presume-se o abandono de emprego se o trabalhador não retornar ao serviço no prazo de 30 (trinta) dias após a cessação do benefício previdenciário nem justificar o motivo de não o fazer"), por meio da qual a jurisprudência firmou critério mais objetivo para caracterização do abandono de emprego, hipótese de justa causa para resilição do contrato de trabalho prevista no art. 482, "i", da CLT, no caso dos autos, conquanto a despedida tenha ocorrido mais de 30 (trinta) dias depois do término do benefício previdenciário, sublinho que, embora o INSS não tenha reconhecido, em sede administrativa, o direito da trabalhadora ao prosseguimento do auxílio-doença, este foi obtido mediante decisão em ação judicial movida em face do Órgão Previdenciário, depois de realizada nova perícia médica, inclusive com pagamento dos valores retroativos.

... Entendo, ainda, que o fato superveniente em questão - concessão do benefício previdenciário em caráter retroativo - acarreta a suspensão do contrato de trabalho, reputando-se, de qualquer sorte, ineficaz a despedida por justa causa aplicada pelo reclamado, ainda que precedida do devido processo administrativo disciplinar.
\end{abstract}

Com efeito, reconhecida a incapacidade laborativa do empregado no momento de sua dispensa, ainda que retroativamente, todos os efeitos da suspensão da obrigação de fazer de prestar serviços passam a se efetivar.

\title{
4.5. A reabilitação no contrato de trabalho e a garantia indireta de emprego
}

O artigo 62 da Lei 8.213/91 estabelece que empregado insusceptível de recuperação para a sua atividade habitual, deverá submeter-se a processo de reabilitação profissional para o exercício de outra atividade, período em que não cessará o benefício do auxílio-doença.

O serviço de reabilitação profissional da previdência social, na forma do artigo 89 da Lei 8.213/91, deve proporcionar ao beneficiário incapacitado parcial ou totalmente para o trabalho, os meios para a (re)educação e de (re)adaptação profissional e social indicados para participar do mercado de trabalho e do contexto em que vive. 
O artigo $93, \S 1^{\circ}$, da Lei 8.213/91 impede a dispensa de trabalhador reabilitado sem a contratação de substituto em condição semelhante:

Art. 93. A empresa com 100 (cem) ou mais empregados está obrigada a preencher de $2 \%$ (dois por cento) a $5 \%$ (cinco por cento) dos seus cargos com beneficiários reabilitados ou pessoas portadoras de deficiência, habilitadas, na seguinte proporção:

$\S 1^{\circ} \mathrm{A}$ dispensa de trabalhador reabilitado ou de deficiente habilitado ao final de contrato por prazo determinado de mais de 90 (noventa) dias, e a imotivada, no contrato por prazo indeterminado, só poderá ocorrer após a contratação de substituto de condição semelhante.

O dispositivo legal transcrito acabou por criar, indiretamente, nova garantia de emprego, porque condiciona a validade do ato de dispensa à contratação de substituto em condição semelhante, havendo entendimento de que se trata de verdadeira estabilidade provisória sem prazo ${ }^{223}$.

Não cumprido o requisito legal, a dispensa é nula e os efeitos da reintegração são inevitáveis:

I - RECURSO DE REVISTA INTERPOSTO POR CHOCOLATES GAROTO S.A. EMPREGADO REABILITADO. ESTABILIDADE. REINTEGRAÇÃO. ART. 93, § 1. ${ }^{\circ}$, DA LEI N 8.213/1991. Esta Corte Superior possui firme jurisprudência no sentido de ser nula a dispensa do empregado reabilitado ou de deficiente habilitado ao final de contrato por prazo determinado de mais de 90 dias, e a imotivada, no contrato por prazo indeterminado, quando a empregadora não cumprir a exigência estabelecida no art. $93, \S 1^{\circ}$, da Lei $n^{\circ}$ 8.213/1991 e, em razão da nulidade da dispensa, o empregado passa a ter o direito de ser reintegrado no emprego. Recurso de revista de que não se conhece.

$\cdots$

II - RECURSO DE REVISTA INTERPOSTO PELO RECLAMANTE. SALÁRIOS VENCIDOS. NULIDADE DA DISPENSA. EFEITO. A Corte Regional decidiu ser indevida a condenação da Reclamada ao pagamento de salários desde a data da dispensa sem justa causa, porque somente quase 06 (seis) meses após tal dispensa, o Autor ingressou com reclamação trabalhista com o objetivo de ser reintegrado no emprego. A Corte Regional concluiu que o pagamento de salário desde a dispensa acarretaria enriquecimento sem causa do Autor. Entretanto, não há enriquecimento sem causa do Reclamante com o pagamento de salário desde a data da dispensa, porque não foi o Autor quem Ihe deu causa. Além disso, foi atendido o prazo prescricional estabelecido no art. $7^{\circ}, \mathrm{XXIX}$, da Constituição Federal entre a dispensa e o ajuizamento da ação. Conforme o

${ }^{223}$ OLIVEIRA, Sebastião Geraldo de. Proteção jurídica ao trabalho dos portadores de deficiência. Apud VIANNA, Cláudia Salles Vilela. op. cit., 2010, p. 100. 
disposto no art. 182 do Código Civil de 2002, -anulado o negócio jurídico, restituir-se-ão as partes ao estado em que antes dele se achavam, e, não sendo possível restituí-las, serão indenizadas com o equivalente-. Recurso de revista de que se conhece e a que se dá provimento.

(Ementa parcial - RR - 300-13.2007.5.17.0003, Relator Ministro: Fernando Eizo Ono, Data de Julgamento: 01/10/2014, 4a Turma, Data de Publicação: DEJT 10/10/2014)

Nessa situação, o Tribunal Superior do Trabalho atribuiu os efeitos da nulidade prevista no artigo 182 do Código Civil, restabelecendo o estado anterior à nulidade, com a consequente reintegração do trabalhador.

O trabalhador readaptado não servirá de paradigma para o direito de equiparação salarial, conforme artigo $461, \S^{\circ}$, da CLT. 


\section{CONCLUSÕES}

A incapacidade laborativa é uma contingência social que aflige a humanidade desde os tempos remotos. Por essa razão, encontram-se desde a antiguidade sistemas de proteção ao enfermo, como os Collegia romanas, as Guildas e Confrarias na Idade Média, bem como a divisão de cultivo de terras das sociedades indígenas pré-colombinas, para solidarizar o afastamento em razão de doença.

Em 1883, na Alemanha, inicia-se a concepção do sistema de previdência social moderno para a proteção ao trabalhador incapacitado. Essa proteção social se alastra por diversos países e, em 1919, forma-se a Organização Internacional do Trabalho. Diversas foram as convenções internacionais que trataram sobre o tema, a maioria não ratificadas pelo Brasil.

O sistema previdenciário brasileiro se iniciou com aplicação voltada a empregados vinculados ao império e, posteriormente, foram reunidas em institutos por categoria profissional. Somente em 1960 ocorreu a unificação do sistema de previdência brasileiro, mas não incluía o trabalhador rural e o doméstico, que passaram a ingressar no sistema previdenciário em 1971 e 1972, respectivamente.

No âmbito do contrato de trabalho, a incapacidade laborativa pode ser definida como a contingência social em que o indivíduo está inapto de desenvolver plenamente suas atividades laborais em razão de alterações morfopsicofisiológicas provocadas por doença ou acidente, contextualizadas no seu ambiente de trabalho.

A incapacidade laborativa total não se confunde com o déficit funcional (incapacidade parcial), porque esta é toda perda ou anormalidade de uma estrutura ou função psicológica, fisiológica ou anatômica; enquanto que aquela é 
a redução ou impossibilidade de realizar uma tarefa específica (laboral ou social) e pode-se classificada em diferentes graus.

A impossibilidade de o empregado cumprir sua obrigação contratual de prestar serviços causada por doença ou acidente é fundamental para a caracterização da incapacidade laborativa, no caso, incapacidade total.

O contrato de trabalho é bilateral ou sinalagmático em sua essência. A principal característica que diferencia os contratos bilaterais dos unilaterais é a existência da cláusula resolutiva tácita e a exceção de contrato não cumprido.

Na fase civilista do Direito do Trabalho, a enfermidade era hipótese de justa causa do prestador de serviços (artigo 1229, I, do Código Civil de 1916). Essas antigas regras civilistas são aplicadas normalmente à prestação de serviços, conforme artigos 248 e 607 do atual Código Civil.

Com o passar do tempo, o caráter tuitivo do Direito do Trabalho passou a aceitar a dispensa do empregado apenas sem justa causa para, finalmente, chegar ao entendimento atual de que inaplicável a cláusula resolutiva tácita ao contrato de trabalho.

Isso ocorreu pelo desenvolvimento do instituto que passou a ser denominado como suspensão do contrato de trabalho, que impede a extinção contratual durante esse período.

Por essa razão, a lei determina que são garantidas as vantagens ao empregado afastado quando retornar ao trabalho (artigo 471 da CLT), o que somente pode ocorrer com a manutenção do contrato de trabalho.

Compreendeu-se que, em verdade, não se suspende o contrato de trabalho, mas apenas seus efeitos, impedindo a extinção contratual. Nesse 
período as cláusulas contratuais estariam congeladas, sem efeitos e, posteriormente, retomariam seu curso após a cessação do motivo causador da suspensão. Somente cláusulas secundárias, de efeitos negativos, como a lealdade, boa-fé, sigilio profissional, permaneceriam em vigor.

A doutrina se apegou desmesuradamente nessa acepção, mais se preocupando em classificar e diferenciar a suspensão total da suspensão parcial, também chamada de interrupção (em que haveria a obrigatoriedade de pagamento de salários, bem como a contagem de tempo de serviço).

Os primeiros 15 dias de afastamento (30 dias após a MP 664/2014) são simplesmente abonos de falta (artigo 60, $4^{\circ}$, da Lei 8.213/91) com o respectivo pagamento integral de salário (artigo $60, \S 3^{\circ}$, da Lei $8.213 / 91$ ), não impedindo a aquisição dos direitos do empregado, salvo aqueles decorrentes da prestação de serviço.

Não atribuiu a devida importância ao fato de que apenas existe uma suspensão da obrigação de fazer consistente em prestar serviços, decorrente de caso fortuito, incidente sobre uma das partes da relação jurídica obrigacional.

O contrato de trabalho, sinalagmático como um todo, e não prestação por prestação, permanece com suas cláusulas integralmente vigentes, sem o congelamento ou suspensão.

O caráter protecionista dessa relação jurídica especial, da mesma forma que impede a cláusula resolutiva tácita, não permite a aplicabilidade da exceção de contrato não cumprido diante dessa situação.

A partir dessas premissas, entendemos que somente os direitos e obrigações que sejam inerentes à prestação de serviços podem deixar de ser cumpridos (vale-transporte, vale-refeição, diárias, etc.) ou estejam a ela correlacionadas (promoção em plano de cargos e benefícios por meritocracia, 
participação nos lucros e resultados, entre outros), de acordo com as normas jurídicas aplicáveis (heterônomas ou autônomas).

A remuneração, por sua vez, não é devida quando o empregado está em licença não remunerada, percebendo auxílio-doença (artigo 476 da CLT), segundo a conceituação prevista na própria lei (artigo 457 e 458 da CLT), porque garantida sua subsistência mínima pela previdência social. Está, portanto, em licença sem remuneração.

Os demais direitos assegurados aos empregados que não dependam direta ou indiretamente da prestação de serviços, como os previstos no artigo 458, §2 $2^{\circ}$ da CLT, permanecem vigentes, como o plano de saúde, além de outros, exemplificativamente: auxílio-farmácia, educação e cesta básica.

A jurisprudência, no mesmo toar da doutrina, apenas repete o dogma de que a suspensão contratual suspende todos os efeitos do contrato de trabalho e que, nos casos de interrupção contratual, são devidos salários o o tempo de serviço. Passou-se, por muito tempo, a decidir as questões segundo a classificação da ocorrência (suspensão ou interrupção contratual).

Esse paradigma passou a ser quebrado e chegou ao Tribunal Superior do Trabalho que, pautado no caráter sinalagmático do contrato de trabalho, a ser aferido de forma global e não prestação por prestação, pacificou jurisprudência sobre a obrigação de manutenção de plano de saúde na suspensão contratual (Súmula 440).

O mesmo raciocínio, de ocorrer apenas a suspensão da obrigação de fazer concernente à prestação de serviços em decorrência de caso fortuito, deve ser aplicado nas situações em que o empregado não recebe o auxílio-doença (no período de carência, por portar doença anterior à filiação previdenciária ou receber alta previdenciária ainda portador de incapacidade laborativa reconhecida pelo médico do trabalho da empresa). Ressalva-se o empregado aposentado em 
que garantida a proteção previdenciária para sua subsistência mínima, o que atenderia o caráter teleológico do artigo 476 da CLT.

Em razão disso, sumariamente, podemos chegar às seguintes conclusões quanto à suspensão da obrigação de fazer consistente em prestar serviços pelo empregado:

a) não suspende o prazo prescricional;

b) não impede a aquisição de férias, salvo se o empregado perceber mais de seis meses de auxílio-doença no mesmo período aquisitivo; mas se garante o período mínimo de gozo de três semanas de férias na superveniência da incapacidade;

c) não receberá gratificação natalina, por decorrer da prestação de serviços;

d) não haverá depósitos de FGTS, salvo quando o empregado receber remuneração ou em razão de auxílio-doença decorrente de acidente de trabalho;

e) impede a concessão de aviso prévio e, na superveniência da incapacidade, os efeitos da extinção contratual somente ocorrerão quando cessada a suspensão contratual, sem prorrogação do prazo;

f) impede a extinção contratual sem justa causa, inclusive no contrato a termo, acarretando na nulidade do ato, com o restabelecimento das partes ao estado anterior, por meio da reintegração do empregado; e

g) possibilita a obtenção de garantia de emprego, quando a incapacidade laborativa deriva de acidente do trabalho por período superior a 15 dias (ou 30 dias após MP 664/2014), implicando na nulidade da dispensa sem justa causa, com a consequente reintegração do empregado. 
Pode-se apontar como grande perspectiva deste trabalho, o aprofundamento da doutrina e jurisprudência quanto aos efeitos da suspensão contratual no contrato de trabalho, a fim de que se afaste o dogma de congelamento automático das cláusulas contratuais, ora advindo de preceito civilista (exceção de contrato não cumprido) completamente incompatível com o Direito do Trabalho na presente situação. 


\section{REFERÊNCIAS BIBLIOGRÁFICAS}

ALLY, Raimundo Cerqueira. Normas Previdenciárias no Contrato de Trabalho. São Paulo: IOB, 2002.

ALVES, Hélio Gustavo. Conversão do auxílio-doença em aposentadoria por invalidez. Revista da Previdência Social, a. 37, nº. 387, p. 110-113, fev. 2013.

LTr, 2007.

, Auxílio-reclusão: direito dos presos e de seus familiares. São Paulo:

ANMP - Associação Nacional dos Médicos Peritos. Em manifestação, presidente da ANMP repudia MP 664 que abre brechas para a terceirização da perícia médica previdenciária. Artigo sem data. Disponível em: <http://www2.anmp.org.br/?p=1442>; acesso em 05 dez 2014.

BARREIRO GONZÁLEZ, Germán. "Reflexiones sobre la suspension del contrato del trabajo". Curitiba: Genesis - Revista de Direito do Trabalho, nº. 107, nov. 2001.

BARROS, Alice Monteiro. Curso de Direito do Trabalho. São Paulo: LTr, 2010.

, "Suspensão e interrupção contratual". [In]: BARROS, Alice Monteiro de (coord.). Curso de direito do trabalho: estudos em memória de Célio Goyatá. São Paulo: LTr, 1997, 781 p.

BATISTA, Flávio Roberto. Benefícios previdenciários por incapacidade no regime geral de previdência social. Dissertação [Mestrado]. São Paulo: Universidade de São Paulo, 2008.

BOMFIM, Benedito Calheiros. A CLT vista pelo Tribunal Superior do Trabalho. Rio de Janeiro: Edições Trabalhistas S/A, 1963.

BUENO, Francisco da Silveira Bueno. Grande Dicionário Etimológico-Prosódico da Língua Portuguesa. 1. ed. São Paulo: Saraiva, 1965.

BUONO NETO, Antonio; BUONO, Elaine Arbex. Perícias judiciais na medicina do trabalho. 3. ed. São Paulo: LTr, 2008. 
CARDONE, Marly Antonieta. Previdência Social e Contrato de Trabalho. Relações. Saraiva, 2011.

CARRION, Valentin. Comentários à Consolidação das Leis do Trabalho. 24. ed. São Paulo: Saraiva, 1999.

CATHARINO, José Martins. Compêndio de Direito do Trabalho. 2. ed. São Paulo: Saraiva, 1981.

, Contrato de Emprego. Salvador: Edição do Autor, 1963.

CESARINO JÚNIOR, Antonio Ferreira. Consolidação das Leis do Trabalho. 4. ed. Rio de Janeiro: Liv. Freitas Bastos S.A., 1956 vol. 1 e 2.

S.A., 1956.

, Direito Social Brasileiro. 1. ed. $2^{\circ}$. vol. Rio de Janeiro: Freitas Bastos

CRUZ, Paulo Marcio. "Fundamentos Históricos, Políticos e Jurídicos da Seguridade Social". [In]: ROCHA, Daniel Machado da; SAVARIS, José Antonio (coord.). Curso de Especialização em Direito Previdenciário. v.1. Curitiba: Juruá, 2005.

CUEVA, Mario de La. IV Congresso Ibero-Americano de Direito do Trabalho e Previdência Social. Vol. I. São Paulo: Editoras Unidas Ltda, 1972.

DALLEGRAVE NETO, José Afonso. Responsabilidade Civil no Direito do Trabalho. 2. ed. São Paulo: LTr, 2007.

DANTAS, Rosa Amélia Andrade Dantas (Org.). Perícia Médica. Estabelecendo Nexo, Avaliando Danos e Constatando Incapacidade. São Paulo: LTr, 2010.

Perícia Médica do Dano Corporal relacionado ao Trabalho. Estabelecendo nexo, avaliando danos e constatando incapacidade. vol 2. São Paulo: LTr, 2012.

DELGADO, Ignácio Godinho. Previdência Social e mercado no Brasil: a presença empresarial na trajetória política social brasileira. São Paulo: LTR, 2001. 
DELGADO, Maurício Godinho. Curso de Direito do Trabalho. 5. ed. São Paulo: LTr, 2006.

LTr, 2001.

Princípios de Direito Individual e Coletivo do Trabalho. São Paulo:

DONATO, Messias Pereira. Curso de Direito do Trabalho. São Paulo: Saraiva, 1975.

FARIAS, Norma; BUCHALLA, Cássia Maria. A classificação internacional de funcionalidade, incapacidade e saúde da organização mundial de saúde: conceitos, usos e perspectivas. Revista Brasileira de Epidemiologia. vol. 8. $\mathrm{n}^{\circ}$. 2. São Paulo: junho/2005.

FELICIANO, Guilherme Guimarães. Curso Crítico de Direito do Trabalho. 1. ed. São Paulo: Saraiva, 2013.

FERRARI, Irany. Dispensa por justa causa no curso de benefício auxílio-doença. Efeitos. 1928-2012. LTr - Suplemento Trabalhista. São Paulo, a. 43, nº 8, p. 32, 2007.

FERREIRA, Aurélio Buarque de Holanda. Novo dicionário Aurélio da língua portuguesa. 3. ed. Curitiba: Positivo, 2004.

FERREIRA, Tatiana; PLÁ RODRIGUEZ, Américo. La seguridade social en el Uruguay. Montevideo: Fundación de Cultura Universitaria. 1984.

GARCIA, Gustavo Filipe Barbosa. Suspensão do contrato de trabalho e dispensa do empregado. São Paulo: Repertório de Jurisprudência IOB. vol. 2, nº. 9, p. 258, $1^{\text {a. }}$ quinz. Maio/2005.

GENTIL, Denise Lobato. A Política Fiscal e a Falsa Crise da Seguridade Social Brasileira - Análise financeira do período 1990-2005. Tese [Doutorado] apresentada ao Programa de Pós-Graduação-Doutorado do Instituto de Economia da Universidade Federal do Rio de Janeiro, 2006. Disponível em:

$<$ http://www.ie.ufrj.br/images/pesquisa/publicacoes/teses/2006/a politica fiscal e a falsa crise da seguraridade social brasileira analise financeira do periodo 1990 2005.pdf>; acesso em: 08 dez 2014. 
GIMENES, Mara Aparecida. Incapacidade laboral e benefício por auxílio-doença no INSS. 1. ed. São Paulo: Ltr, 2014.

GOMES, Orlando. Questões de Direito do Trabalho. 1. ed. São Paulo: LTr, 1974.

, Obrigações. 12. ed. Rio de Janeiro: Forense, 1999.

Contratos. 21. ed. Rio de Janeiro: Forense, 2000.

GOMES, Orlando; GOTTSCHALK, Elson. Curso de Direito do Trabalho. 14. ed. Rio de Janeiro: Forense, 1997.

GONÇALVES, Lilian. Aposentadoria por invalidez: análise crítica de seus efeitos no contrato de trabalho. Tese [Doutorado] apresentada ao Curso de Direito do Trabalho e Seguridade Social da Faculdade de Direito da Universidade de São Paulo, São Paulo, 2012, 162f. Disponível em:

$<$ http://www.teses.usp.br/teses/disponiveis/2/2138/tde-18022013-112553/ptbr.php>; acesso em 08 dez 2014.

GONÇALVES, Odonel Urbano. Manual de Direito Previdenciário. Acidentes do Trabalho. 10. ed. São Paulo: Atlas, 2002.

HOUAISS, Antônio; VILLAR, Mauro de Salles. Dicionário Houaiss da Língua Portuguesa. 1. ed. Rio de Janeiro: Objetiva, 2001.

INSS - Instituto Nacional do Seguro Social. Manual de Perícia Médica da Previdência Social - versão 2. p. 25. Disponível em: http://www.ieprev.com.br/userfiles/file/tabela\%20de\%20teto \%20inss/manualdepericiasmedicasdoINSS.pdf; acesso em 01 dez 2014;

- Manual de Procedimentos de Benefícios por Incapacidade (MPBI) Volume l: Diretrizes de Apoio à Decisão Médico-Pericial em Ortopedia e Traumatologia, 2008. Disponível em: <http://www.ieprev.com.br/userfiles/file/diretrizesortopedia_consultapublicaabril2008.pdf>; acesso em 04 dez 2014;

Manual de Procedimentos de Benefícios por Incapacidade. Diretrizes de Apoio à Decisão Médico-Pericial em Psiquiatria. Diretoria Saúde do trabalhador. Volume II, 2010. Disponível em: 
$<$ http://www.uniad.org.br/desenvolvimento/images/DIRETRIZES\%20DE \%20APOIO\%20A\%20DECIS\%20EM\%20PSIQUIATRIA1.pdf>; acesso em 05 dez 2014 ;

Manual de Procedimentos de Benefícios por Incapacidade. Diretrizes de Apoio à Decisão Médico-Pericial em Clínica Médica. Volume III Parte II. HIVIAIDS, Tuberculose e Hanseníase. Brasília, 2014. Disponível em:

$<$ http://www3.dataprev.gov.br/sislex/paginas/77/MANUAL_BENEFICIO/res416.pdf $>$; acesso em 05 dez 2014.

- Manual de Reconhecimento Inicial de Direitos - Volume IV.

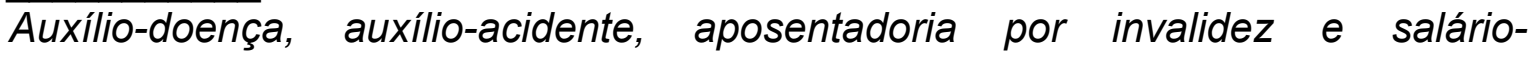
maternidade. Dezembro/2012, p. 12. Disponível em: http://edgardconsultores.com/wp-content/uploads/files/Manual_RI_Direitos-Dez2012.pdf; acesso em 01 dez 2014;

Diretoria de Benefícios. Procuradoria Federal Especializada. Orientação Interna Conjunta No 01 DIRBEN/PFE, de 13 de Setembro de 2005.

KRAVCHYCHYN, Gisele Lemos. Do direito a continuidade de pagamento em casos de pedido de prorrogação do benefício de auxílio doença. Jus Navigandi, Teresina, ano 18, $\mathrm{n}^{\circ}$. 3769, 26 out. 2013. Disponível em: <http://jus.com.br/artigos/25571>; acesso em 05 dez 2014.

LAMARCA, Antonio. Contrato Individual de Trabalho. São Paulo: Revista dos Tribunais, 1969.

Contrato de trabalho interrupção, suspensão extinção por causas estranhas à vontade das partes; estudo doutrinário, com vistas ao direito comparado e à jurisprudência dos tribunais. São Paulo: Revista dos Tribunais, 1959.

LEITE, Carlos Henrique Bezerra. Curso de Direito do Trabalho. 1. ed. São Paulo: Saraiva, 2014.

LESSA, CARLOS. O Rio de todos os Brasis. 1. ed. Rio de Janeiro: Record, 2000.

LINS, Edilberto Quintela Vieira. Incapacidade executiva de trabalho e contrato de emprego: direito do trabalho e previdência social. Imprenta: Rio de Janeiro: Forense, 1984, 213p. 
MACHADO FILHO, Sebastião. Suspensão do Contrato de Trabalho e outros estudos. 1. ed. São Paulo: Ltr, 1986.

MAGANO, Octávio Bueno. Lineamentos de Direito do Trabalho. 2. ed. São Paulo: LTr, 1972.

, Suspensão do contrato de trabalho. São Paulo: Revista Synthesis, n. 30, p. 120-22, jan./jun. 2000.

MAIOR, Jorge Luiz Souto. Doença profissional: aplicação do art. 118 da Lei 8.213/91. Ausência de auxílio-doença. Boletim Informativo do TRT - 15a . Região. Campinas, $n^{\circ} .186$, p. 59-67, jan./fev. 2004.

MARTINEZ, Wladimir Novaes. Curso de Direito Previdenciário. 3. ed. São Paulo: LTr, 2014.

MARTINS, Sérgio Pinto. Direito do Trabalho. 26. ed. São Paulo: Atlas, 2010.

Direito da Seguridade Social. 22. ed. São Paulo: Atlas, 2005.

MAZZONI, Giuliano. Manuale di Diritto Del Lavoro. 5. ed.; vol. 1 e 2, Milão: Giuffrè Editore, 1977.

MUSSI, Cristiane Miziara. Os efeitos do recebimento dos benefícios previdenciários no contrato de trabalho. Doutorado em Direito Previdenciário. São Paulo: Pontifícia Universidade Católica, 2007.

NASCIMENTO, Amauri Mascaro. Curso de Direito do Trabalho. 20. ed. São Paulo: Saraiva, 2005. Iniciação ao Direito do Trabalho. 24 ed. São Paulo: Ltr, 1998.

NATURE - INTERNATIONAL WEEKLY JOURNAL OF SCIENCE. Incapacidade Permanente. Disponível em: 
$<$ http://www.nature.com/nature/journal/vaop/ncurrent/full/nature13974.html>; acesso em 03 de dezembro de 2014.

NÓBREGA, Vandick Londres da. História e Sistema do Direito Privado Romano. 1. ed. Rio de Janeiro: Freitas Bastos, 1959.

NOVAES FILHO, Wladimir. Avaliação de incapacidade laborativa - Benefícios previdenciários - Normas técnicas. 1. ed. São Paulo, 1998.

OLIVEIRA, Marcel Thiago de. Alta programada: afronta ao princípio da dignidade da pessoa humana. Jus Navigandi, Teresina, ano 14, $\mathrm{n}^{\circ}$. 2151, 22 maio 2009. Disponível em: <http://jus.com.br/artigos/12882>; acesso em 05 dez 2014.

OLIVEIRA, Moacyr Velloso de. Influência do Direito Previdenciário ou da Seguridade Social sobre o Direito do Trabalho. Revista da Previdência Social, vol. 13, maio de 1989.

OLIVEIRA, Sebastião Geraldo de. Indenizações por Acidente do Trabalho ou Doença Ocupacional. 3. ed. São Paulo: LTr, 2007.

OMS - Organização Mundial de Saúde. CIF - Classificação Internacional de Funcionalidade, Incapacidade e Saúde. Organização Mundial de Saúde. Lisboa, 2004. Disponível em:

$<$ http://www.periciamedicadf.com.br/cif2/cif_portugues.pdf >; acesso em $04 \mathrm{dez}$ 2014.

ORGANIZACIÓN INTERNACIONAL DEL TRABAJO. La seguridad em cifras. Ginebra: Ofinica Internacional del Trabajo, 2003.

PASSARELLI, Santoro. Noções de Direito do Trabalho. 1. ed. São Paulo: Editora Revista dos Tribunais, 1973.

PASSOS, Nicanor Sena. Despedida sem justa causa. Gozo de auxílio-doença. Cabimento. Jornal Trabalhista. Brasília, a. 14, nº 680, p. 1050-1048, 13 out. 1997.

PENTEADO, José Marcelo de Oliveira. Deficiência funcional vs. incapacidade laboral. LTR - SUPLEMENTO TRABALHISTA. São Paulo, a. 50, nº. 94, p. 433435, 2014. 
PIMPÃO, Hirosê. O aviso prévio no Direito do Trabalho. 2. ed. Rio de Janeiro: José Doinfino Editor, 1958.

REALE, Miguel. Lições preliminares de direito. 24. ed. São Paulo: Saraiva, 1998.

LTr - Legislação do Trabalho. Ações Regressivas que visam ao ressarcimento, à União, dos gastos relativos às Prestações Sociais (Saúde e Previdência) decorrentes de Acidentes do Trabalho - Exxito das Ações regressivas em decorrência do Convênio do TST com a Procuradoria Geral Federal. Publicação mensal de Legislação, Doutrina e Jurisprudência. Ano 78. $n^{\circ}$. 4, p.390. Abril de 2014. SP, Brasil.

ROMITA, Arion Sayão. Direitos fundamentais nas relações de trabalhado. 3. ed. São Paulo: Ltr, 2009.

RUSSOMANO, Mozart Victor. Comentários à Consolidação das Leis do Trabalho. 4. ed.; Rio de Janeiro: Revista dos Tribunais, 1977.

O Empregado e o Empregador no Direito Brasileiro. 3 ed. Rio de Janeiro: Konfino, 1958.

SAAD, Eduardo Gabriel. Suspensão do contrato de trabalho e segurodesemprego. São Paulo: LTr - Suplemento Trabalhista. São Paulo, n. 176, p. 827, 1998.

Ltr, 2014.

, Consolidação das Leis do Trabalho Comentada. 47. ed. São Paulo:

SEBRAE - Serviço Brasileiro de Apoio às Micro e Pequenas Empresas. Participação das Micro e Pequenas Empresas na Economia Brasileira. Brasília, julho/2014.

SCHWARZ, Rodrigo Garcia e outros. Dicionário de direito do trabalho, de direito processual do trabalho e de direito previdenciário aplicado ao direito do trabalho. 1. ed. São Paulo: LTR, 2012.

Secretaria de Comunicação Social do STF. Questionadas MPs que alteraram benefícios trabalhistas e previdenciários. Artigo publicado em 03 de fevereiro de 
2015. Disponível em: <http://www.stf.jus.br/portal/cms/verNoticiaDetalhe.asp? idConteudo=284624>; acesso em 26 fev 2015.

SILVA, De Plácido e. Vocabulário Jurídico. 4. ed. São Paulo: Forense, 1975.

SILVA, Homero Batista Mateus da. Curso de direito do trabalho aplicado: parte geral. Rio de Janeiro: Campus Elsevier, 2013. vol. 1.

Curso de direito do trabalho aplicado: contrato de trabalho. Rio de Janeiro: Campus Elsevier, 2009. vol. 6.

SSP - Secretaria de Segurança Pública do Estado de São Paulo. Falsários são presos durante venda de atestado médico. Matéria divulgada em 05 de julho de 2013. Disponível em:<http://www.ssp.sp.gov.br/noticia/lenoticia.aspx?id=31706>; acesso em 05 dez 2014.

SOARES, Saulo Cerqueira de Aguiar; SOARES, Ivna Maria Mello. Limbo trabalhista-previdenciário: médico do trabalho e médico do INSS. - reflexões médicas, éticas e jurídicas acerca dos aspectos polêmicos. Instituto de Estudos Previdenciários, Belo Horizonte, ano 08, $n^{\circ}$. 313, 09 junho 2014. Disponível em: $<$ http://www.ieprev.com.br/conteudo/id/34721/t/limbo-trabalhista-previdenciario:medico-do-trabalho-e-medico-do-inss:---reflexoes-medicas, -eticas-e-juridicasacerca-dos-aspectos-polemicos>; acesso em 15 dez 2014.

SÜSSEKIND, Arnaldo Lopes; MARANHÃO, Délio; VIANNA, Segadas; TEIXEIRA, Lima. Instituições de Direito do Trabalho. 22. ed. São Paulo: LTr, 2005.

SÜSSEKIND, Arnaldo Lopes. Previdência Social Brasileira. Rio de Janeiro: Freitas Bastos, 1955.

TAVARES, Marcelo Leonardo. Direito previdenciário. 3. ed. Rio de Janeiro: Lúmen Júris, 2001.

, Previdência e assistência social: legitimação e fundamentação constitucional brasileira. Rio de Janeiro: Lúmen luris, 2003. 
TEIXEIRA, Eduardo Didonet. Considerações sobre o auxílio-doença e a aposentadoria por invalidez. Direito Federal: Revista da AJUFE. Brasília, a. 20, nº. 68, p. 143-56, out./dez. 2001.

TREVISO, Marco Aurélio Marsiglia. A competência da Justiça do Trabalho, a incapacidade laborativa do trabalhador e os benefícios previdenciários. São Paulo: Ltr, 2012.

VESCOVI, Luiz Fernando; SOARES, João Marcelino. Auxílio-doença e implicações trabalhistas. Justiça do Trabalho. Porto Alegre, a. 28, nº. 334, p. 5876, out. 2011.

VIANNA, Cláudia Salles Vilela. A relação de emprego e os impactos decorrentes dos benefícios previdenciários. 2. ed. São Paulo: LTR, 2010.

VIANNA, João Ernesto Aragonés. Curso de Direito Previdenciário. São Paulo: LTr, 2007.

WALDMAN, Tatiana Chang. "Doença”. [In]: SCHWARZ, Rodrigo Garcia, 1971(org.). Dicionário de direito do trabalho, de direito processual do trabalho, de direito previdenciário aplicado ao direito do trabalho. São Paulo: LTr, 2012. p. 393-394. 